\title{
"O JESU VIVENS IN MARIA": DEVOTION TO THE INFANT JESUS AND IMITATION OF THE HOLY FAMILY AMONG THE DISCALCED CARMELITES OF BEAUNE, 1619-1700
}

\author{
by
}

Julie Tracz, B.A

\begin{abstract}
A thesis submitted to
the Faculty of Graduate Studies and Research in partial fulfillment of the requirements for the degree of
\end{abstract}

Master of Arts

Department of History

\author{
Carleton University \\ Ottawa, Ontario \\ August 4, 2009 \\ (C) Copyright \\ 2009, Julie Tracz
}




\section{Library and Archives \\ Canada}

Published Heritage

Branch

395 Wellington Street Ottawa ON K1A ON4 Canada
Bibliotheque et

Archives Canada

Direction du

Patrimoine de l'édition

395 , rue Wellington

Ottawa ON K1A ON4

Canada
Your file Votre reférence
ISBN: 978-0-494-60274-4
Our file Notre référence
ISBN: $978-0-494-60274-4$
NOTICE:

The author has granted a nonexclusive license allowing Library and Archives Canada to reproduce, publish, archive, preserve, conserve, communicate to the public by telecommunication or on the Internet, loan, distribute and sell theses worldwide, for commercial or noncommercial purposes, in microform, paper, electronic and/or any other formats.

The author retains copyright ownership and moral rights in this thesis. Neither the thesis nor substantial extracts from it may be printed or otherwise reproduced without the author's permission.

\begin{abstract}
AVIS:
L'auteur a accordé une licence non exclusive permettant à la Bibliothèque et Archives Canada de reproduire, publier, archiver, sauvegarder, conserver, transmettre au public par télécommunication ou par l'Internet, prêter, distribuer et vendre des thèses partout dans le monde, à des fins commerciales ou autres, sur support microforme, papier, électronique et/ou autres formats.
\end{abstract}

L'auteur conserve la propriété du droit d'auteur et des droits moraux qui protège cette thèse. $\mathrm{Ni}$ la thèse ni des extraits substantiels de celle-ci ne doivent être imprimés ou autrement reproduits sans son autorisation.
In compliance with the Canadian Privacy Act some supporting forms may have been removed from this thesis.

While these forms may be included in the document page count, their removal does not represent any loss of content from the thesis.
Conformément à la loi canadienne sur la protection de la vie privée, quelques formulaires secondaires ont été enlevés de cette thèse.

Bien que ces formulaires aient inclus dans la pagination, il n'y aura aucun contenu manquant.

\section{Canadä}




\begin{abstract}
This thesis examines the devotion to the infant Jesus among the Discalced Carmelite nuns of Beaune from 1619-1700. It examines the ways in which the nuns' devotional practices, both physical and mental, were based on the imitation of the Holy Family. The Carmelites of Beaune practiced their devotion to the infant Jesus through the imitation of Mary and Joseph's thoughts and emotions. The nuns also imitated Mary in physical ways by seeing themselves as receptacles of Christ through the reception of the Eucharist and by caring for the infant Jesus. The Carmelites also modelled their lives on that of the infant Jesus by developing his childlike qualities and by participating in the suffering of his Passion. The devotions of the Beaune convent were deeply connected to the spirituality of the école française and efforts of Catholic renewal in France. Ultimately, this thesis seeks to explore the unique ways in which the Carmelites of Beaune practiced the devotion to the infant Jesus and its role within seventeenth-century French spirituality.
\end{abstract}




\section{Acknowledgements}

I owe a number of people gratitude for their help, support and encouragement during the process of completing this thesis. The guidance and feedback of my supervisor, Dr. Paul Nelles were always a great support. My meetings with him always left me feeling better about my project and eager to continue working. I am grateful to Dr. Nelles for his confidence in me and his constant assurances. Dr. Marc Saurette and Dr. Rod Phillips also helped me throughout this process. Conversations with each of them inspired me to pursue subjects that have always interested me. I am thankful for their willingness to discuss my work with them and for helping me navigate through the maze of understanding monasticism and early-modern France.

I do not think that I could have successfully gone through the process of writing this thesis without the support of my fellow M.A. students. I am incredibly indebted to Corinna Prior and Ward Minnis for our lengthy meetings, during which we shared our struggles and successes of thesis-writing. My many conversations with Corinna always gave me a renewed perspective on my thesis and reminded me that other people care about understanding monasticism as much as I do.

This thesis would not be what it is had I not travelled to Beaune, France. This trip allowed me to visit the Discalced Carmelite nuns of Beaune, share my research with them, and learn from them. I am particularly grateful to Sr. Jehanne d'Arc who welcomed by husband and I into her convent and who shared with us her great knowledge and wisdom of the devotion to the infant Jesus. She also provided me with photographs and descriptions of seventeenth-century paintings, statues and other 
devotional objects. I also want to thank Sr. Marie Benedicte who also sent me photographs and offered to assist me in any way she could.

My friends and family have also played a large role in the completion of this thesis by asking how I was progressing, believing in my ability to write well and quickly, and for reminding me that there is life beyond my thesis.

I want to thank my husband, Kamil, who has been with me throughout this entire process. Thank you, Kamil for being a wonderful and supportive husband throughout the struggles and joys of writing this thesis.

Since this thesis began primarily with an interest to learn and understand more about my Catholic faith, I must, of course, thank God. I am grateful for the constancy and the beauty of His Church. 


\section{Table of Contents}

$\begin{array}{lll}\text { Abstract } & \text { ii }\end{array}$

Acknowledgements $\quad$ iii

Table of Contents $\quad$ v

List of Figures vi

Introduction 1

1. Recent Scholarship

2. Defining a Period: Early Modern Catholicism

3. Conceptual Considerations: Imitation, Performance, and Ritual

4. A Word on Sources: The Documents from Beaune

Chapter One: Historical and Spiritual Context of Beaune

1. Seventeenth-century Beaune: Recent History

2. Founding of the Beaune Convent

3. The Infant Jesus, l'École Française and the Spirituality of Beaune

Chapter Two: Imitation of Mary

1. "Sa maternité divine:" Representations of Motherhood

2. Contemplating Mary and Joseph's Dispositions

3. “Temples de Grâce:" Becoming Vessels of the Infant Jesus

4. Embracing and Cradling the Infant Jesus

Chapter Three: Imitation of the Infant Jesus

1. "L'enfance spirituelle:"' Representations of Childlike Qualities

2. "De l'enfance à la croix:" Representations of Christ's Passion

3. Beaune as Bethlehem: Living "la vie cachée" with the Holy Family

4. "Victime de sa crèche:" Participating in Christ's Suffering

Conclusion 


\section{List of Figures}

1. Statue of Mary and the infant Jesus, Beaune convent, seventeenth century

2. "Roi de Grâce" statue of the infant Jesus, Beaune convent, 1643.

3. Shrine of the Virgin, Metropolitan Museum of Art, ca. 1300.

4. La Vierge à l'Enfant apparaissant à la Bienheureuse soeur Marie de l'Incarnation (1565-1618), Collection Carmélitaine, seventeenth century

5. Painting of the Nativity, Beaune convent, seventeenth century

6. Engraving of Marguerite du Saint Sacrement and the infant Jesus, Archives du Carmel, 21,54 , seventeenth century

7. Painting of Marguerite du Saint Sacrement holding the infant Jesus, Beaune convent, seventeenth century

8. Drawing of Marguerite du Saint Sacrement and the infant Jesus, Archives du Carmel, 21,43 , seventeenth century 


\section{Introduction}

" $L$ 'enfance du petit Jésus... doit être notre vie, notre joie et notre force. Nous ne devons regarder que lui, chercher ni aimer que lui.",

In 1562 Teresa of Avila established the order of the Discalced Carmelite nuns.

Prompted by the Council of Trent and the desire to strengthen the contemplative religious life, Teresa of Avila succeeded in reforming the Carmelite order. Originating in Spain, the order quickly spread elsewhere. By October 15 1604, a group of six Spanish nuns arrived in Paris, establishing the first Discalced Carmelite convent in France. ${ }^{2}$ With the support of the Oratorian priests, over thirty Discalced Carmelite convents were founded throughout France during the seventeenth century.

The success of this reform and the widespread establishment of Discalced Carmelite convents throughout France speak to the renewed vigour of early modern Catholicism. Much of the spiritual fervour of Catholicism in France was concerned with the reform of religious orders and the battle against heresy. ${ }^{3}$ During this time new monastic communities developed, building upon traditional orders and also establishing new congregations. This period, particularly in France, was a time of foundations and of an influx of vocations. ${ }^{4}$ Additionally, new devotions developed within Catholic spirituality and in the early seventeenth century the Church developed and encouraged new practices and methods of devotion among religious and laity alike. ${ }^{5}$

\footnotetext{
${ }^{1}$ Marie-Françoise Grivot, ed., Marguerite du Saint-Sacrement: Correspondance, lettres écrites par elle, reçues par elle et écrites à son sujet (Habillages: Beaune, 1991), 34. Letter from Marguerite du Saint Sacrement to Marguerite de Saint-Alexis at the Mâcon convent, dated August 24, 1637. "The infancy of the little Jesus...must be our life, our joy and our strength. We must not look but at him, seek nor love but him."

${ }^{2}$ Stéphane-Marie Morgain, Pierre de Bérulle et les Carmélites de France: la querelle du gouvernement 1583-1629 (Paris: Les Éditions du Cerf, 1995), 8.

${ }^{3}$ Ibid., 56.

${ }^{4}$ Ibid., 8 .

${ }^{5}$ Louis Châtellier, Le Catholicisme en France, 1500-1650, tome I: le XVIe siècle (Paris: Sedes, 1995$), 185$.
} 
One such development was the devotion to the infant Jesus. Although not exclusive to the early modern period this devotion received new attention and was adopted with vigour by the Discalced Carmelites. A favourite of Teresa of Avila, devotion to the infant Jesus characterized the Spanish convents and this tradition strongly continued among those in France. Not only did the French nuns appropriate the Carmelite devotion to the infant Jesus, but they made it their own by integrating it within and adapting it according to current spiritual trends within France. A small, poor convent in Beaune formed the hub of this spirituality in France. Indeed the Beaune convent propagated a new form of devotion to the infant Jesus. ${ }^{6}$

This thesis examines the devotion to the Infant Jesus among the Discalced Carmelites of Beaune and the ways in which their devotional practices, both physical and mental, were based on the imitation of the Holy Family. I argue that the Carmelites of Beaune practiced and embodied their devotion to the infant Jesus by performing acts of maternal affection towards the infant Jesus and by modelling their lives on his example. By using Mary and Joseph as models of imitation and guides for the spiritual life, the Discalced Carmelites practiced their devotion to the Infant Jesus by becoming mothers of Christ. In addition, the nuns imitated the infant Jesus in order to become a child like him, one of the central aims of Carmelite spirituality.

In order to explore the devotional practices of the Carmelites of Beaune I have divided this thesis thematically. This introductory chapter is followed by a chapter devoted to the historical and religious context of seventeenth-century Beaune. This chapter situates Beaune and its Discalced Carmelite convent within a relevant historical

\footnotetext{
${ }^{6}$ Jacques Roland-Gosselin, Le Carmel de Beaune: 1619-1660 (Morocco: Imprimeries Françaises et Marocaines, 1969), 136.
} 
context and provides an analysis of the spiritual milieu of the time, specifically with regards to the devotion to the infant Jesus. Chapter Two delves into the writings, images and devotional behaviours of the Carmelites of Beaune by looking at the imitation of Mary's motherhood. The Carmelites of Beaune imitated Mary, and to some extent Joseph, in order to become spiritual mothers of the infant Jesus. They did so through mental and physical devotional activities, such as contemplating Mary and Joseph's thoughts and emotions as well as physically caring for the Christ Child. The final chapter explores the nuns' imitation of the infant Jesus himself. By imitating the qualities and virtues of the divine infancy as well as the suffering of Christ's Passion, the Carmelites of Beaune united themselves with the infant Jesus.

\section{Relevant Scholarship}

A number of areas of historical scholarship are relevant to the present study. This thesis addresses topics such as early modern Catholicism, female religious orders, the devotion to the Holy Family, the spirituality of seventeenth-century France, and the appropriation and behavioural expression of devotion and imitation. While it would be a difficult task to provide anything akin to a complete review of the scholarship of all of these subjects as they relate to this thesis, I will provide an overview of the most significant scholarship for the study of the devotion to the infant Jesus among the Discalced Carmelites of Beaune. This section is divided into four areas: studies concerning female monasticism in early modern France, Discalced Carmelite studies, recent scholarship regarding Mary's motherhood, and studies of the devotion to the infant Jesus. Discussion of these topics will help to situate the present study of the Beaune 
Carmelites within current scholarship. This thesis seeks to remedy a historiographical void in terms of how scholars have studied the Discalced Carmelites of France as well as the ways in which historians have studied female religious orders of the early modern period. There is a need to bring a renewed perspective on the study of female religious orders and early modern Catholicism that involves an intentional and thorough analysis of the spirituality and devotional lives of nuns.

Female Monasticism in Early Modern France

The study of female monasticism in early modern Europe has been the subject of much historical inquiry in recent years. An exploration of the spiritual lives of the Discalced Carmelites of Beaune necessarily falls into this category. For this reason, I will take some time to survey some important contributions to the historiography of early modern female monasticism, considering the dominant themes and debates as well as carving out a place for the current study. Although much has been done to help our understanding of women's religious orders, little has been said regarding the spirituality and devotional lives of nuns. I argue that there is a historiographical ignorance of the spiritual lives of nuns. There is a need to gain a greater understanding of the experiences of nuns and the dynamics of early modern monastic life. Historians of women and early modern religion must pay more attention to the study of the inner workings of early modern convents and the spiritual lives of the women who resided there. While such historical inquiry is largely lacking for the early modern period, studies of medieval women and religion, most notably the work of Carolyn Walker Bynum, explore the 
spirituality and devotional behaviours of nuns. ${ }^{7}$ We need for the early modern period what Bynum has done for the medieval period, that is, an effort to delve into the spirituality and devotional behaviour of female monasticism. This thesis seeks to begin this endeavour in the continuing pursuit to uncover the lives and experiences of nuns.

This discussion of early modern female monasticism is focused on two areas that seem to dominate scholarship in this field: debates regarding the degree to which the religious life offered opportunities for authority and power to women, and the nature and value (or lack thereof) of the cloistered contemplative life. By focusing on these two areas I intend to explain what has been studied as well as the deficiencies of the historiography and the need to question the ways in which we study female monasticism. As I will explain, most of these studies focus not on the spirituality of the nuns, but on their assertion and acquisition of power, their relationships with male ecclesiastics, and the negative impact of claustration. While such studies help us to understand aspects of female monasticism during the early modern period, they do not tell us about the prayer lives and behaviours of nuns or how they interacted with the divine through particular thoughts, emotions and behaviours. Little has been said regarding religious women's devotional behaviours or the ways in which they practiced and embodied spirituality. Consequently we do not at present have a full understanding of claustration and the contemplative life as experienced by early modern nuns.

\footnotetext{
'In her book Holy Feast and Holy Fast: The Religious Significance of Food to Medieval Women (Los Angeles: University of California Press, 1987), Bynum explores the relationship between medieval women and food. Bynum focuses on the devotional behaviours and mentalities of medieval women, many of whom were nuns. She analyses the religious significance of food and explores issues such as fasting, Eucharistic devotion, bodily mortification, and mystical visions. In doing so, Bynum provides a detailed analysis of female piety during the medieval period. Studies such as this are necessary in order to complement those that focus on other aspects of monastic life. Analysis of the spiritual lives of nuns and of the inner workings of convent life, especially in terms of devotional behaviours, is essential to understanding all facets of female monasticism. Bynum provides an in depth study of this nature and it is hoped that future historiography will continue in this vein.
} 
One of the common themes in the historiography of female monasticism is the extent to which women were able to achieve power and authority through the religious life. Most often, scholars frame such discussions in the context of a male dominated hierarchy from which women were largely excluded. In doing so, such historians reduce women's behaviour to that which opposes their male superiors. This perspective also presumes the subjugation of women to their male counterparts in a purely negative light, thus constantly reaffirming male authority as demeaning for women. Though historians generally agree that women were able to exercise a certain degree of power and authority within the religious life, they vary in their opinions regarding the extent to which this was possible and achieved. Charmarie Blaisdell has analysed the empowerment of aristocratic women in convents, particularly during the period of Catholic reform in the middle of the sixteenth century. ${ }^{8}$ Blaisdell suggests that in the context of the Protestant Reformation and after, women had more opportunities to exercise power, particularly within the convent setting. ${ }^{9}$ Separated from their families and their male family members, aristocratic women were able to make decisions and act independently.

The prominent historian of women's religious communities Elizabeth Rapley supports the claim that nuns held power and influence within their convents. Rapley explains that this was contrary to the experiences of Protestant women who enjoyed less "opportunities for organizational activity." ${ }^{10}$ Rapley argues further that during the late sixteenth century, Catholic women, specifically those pursuing the religious life, were the

\footnotetext{
${ }^{8}$ Charmarie Blaisdell, "Religion, Gender, and Class: Nuns and Authority in Early Modern France," in Changing Identities in Early Modern France, ed. Michael Wolfe (Durham: Duke University Press, 1997), 147-168.

${ }^{9}$ Ibid., 147.

${ }^{10}$ Elizabeth Rapley, The Dévotes: Women and Church in Seventeenth-Century France (Montreal: McGillQueen's University Press, 1990), 5.
} 
centre of religious revival. This began a period of intense feminization of the Church, characterized by a "distinct imprint of feminine spirituality." "While I think Rapley may be quite right, her book stops short of analyzing the nature, characteristics and practices involved in this spirituality. While this thesis does not explicitly argue that a particularly "feminine spirituality" existed, it does explore the devotional behaviours of a distinct group of religious women who practiced a very particular spirituality through their devotion to the infant Jesus.

Though the arguments that the religious life offered opportunities of power and authority to nuns shed some light on female monasticism, most of the discussion is framed in terms of male authority, thus emphasizing women's efforts to subvert and avoid male dominance. This aspect of the historiography needs to be reconsidered as it places undue emphasis on gender differences and assumes the overall desire of women to undermine their male counterparts. Certainly some women consciously sought to subvert the traditional male hierarchy and of course, gender inequalities should be recognized and considered. But by focusing on the dichotomy between male and female authority and by studying women's power strictly in relation to that of men, scholars risk overlooking the motivations and intentions of women which do not always struggle against those of men. Barbara Diefendorf echoes this sentiment. She writes that this period is often portrayed as "particularly hostile" towards women and a time in which "misogynistic male clerics reinforced their domination of church institutions." ${ }^{\text {"12 }}$ Though she admits that the postTridentine Church aimed to reinforce rules of strict claustration, she argues that:

\footnotetext{
${ }^{11}$ Ibid.

${ }^{12}$ Barbara Diefendorf, From Penitence to Charity: Pious Women and the Catholic Reformation in Paris (Oxford: Oxford University Press, 2004), 9.
} 
portraying women as hapless victims of repressive clerics, church dogmas, and family strategies deflects attention from investigation of their own religious values and choices.

Some women enthusiastically supported the call for spiritual and institutional renewal that issues from the Council of Trent; others felt well served by traditional institutions and resisted dramatic change. Advocates and opponents of Catholic renewal did not divide along simple gender lines. ${ }^{13}$

This is precisely the position of my study. While gender differences and conflict cannot be overlooked, the motivations and desires of nuns are at the forefront of my analysis. I agree with Diefendorf's argument that women, particularly nuns, must be seen as individuals capable of independent thought and action in acceptance of and even embracing the traditional institutional order. My analysis of the spiritual lives of the Carmelites of Beaune attempts to consider the particular behaviours of the nuns in their devotion to the infant Jesus. Issues of male superiority, in terms of the Oratorian priests who acted as the order's ecclesiastical superiors and confessors, are related to my analysis since many sources were written by these priests for the nuns. These sources will be analyzed with a view to understanding the kind of spirituality and devotional activities that were encouraged, practiced and embodied by the nuns themselves. I believe that by focusing on the spirituality of female monasticism, rather than assuming a constant struggle for power against male subversion, historians have a better chance of understanding the lives of women in religious communities. At the very least, studies of this kind will add a new dimension to our understanding of the lives of early modern nuns.

The second theme of academic attention on female monasticism is the debate over the impact of claustration on the lives of religious women. This concerns the topic of this

${ }^{13}$ Ibid. 
thesis more directly as the Discalced Carmelites of Beaune were cloistered contemplative nuns. Furthermore, some aspects of their devotion to the infant Jesus, such as comparisons between the crèche and the convent, serve as reminders of the importance of claustration and its significance in the lives of the nuns. In recent scholarship claustration is most often discussed in terms of the dichotomy between the cloistered, contemplative life and the active apostolate. These two varieties of the female religious life are often viewed in opposition to one another, frequently portraying claustration as oppressive and the active life as liberating. I argue that this approach to the study of female monasticism is unnecessarily restrictive in that it assumes the superiority of the active religious orders over the contemplative. Placing undue emphasis on what some consider the oppressive nature of the cloistered life limits our understanding of the lives of the nuns who lived within the convent walls. If we continue to understand the cloistered religious orders in this way, we lose sight of trying to uncover how these nuns lived and the meaning and significance they often drew from their way of life.

In her book From Penitence to Charity, Barbara Diefendorf dedicates three chapters to a discussion of claustration. ${ }^{14}$ Diefendorf explores the degree to which the enforcement of strict enclosure was successful and the attitudes of women and Church officials towards claustration. She also analyzes enclosure among the new reformed orders of the seventeenth century, and the active orders that originated during this time. Throughout, Diefendorf is careful to highlight the complexities of maintaining strict claustration. In a discussion of the arrival of the Discalced Carmelites nuns in France, Diefendorf writes that "the Carmelites needed to maintain a delicate balance between the contemplative retreat they desire and the cultivation of lay sponsorship necessary to their

\footnotetext{
${ }^{14}$ Ibid., 101-201.
} 
survival." ${ }^{\prime 15}$ Despite their physical removal from the secular world, cloistered nuns, including the Carmelites of Beaune, remained dependent on the outside world for financial support.

An important aspect of Diefendorf's work is her explanation of the ways in which nuns supported and actively sought the cloistered, contemplative life. She acknowledges that many nuns of the early modern period sought stricter claustration for female religious communities. This is contrary to other scholars, such as Mary Wiesner, who argues that women more often than not fought against claustration and preferred to pursue their ministry in public. Although female monasticism forms only a part of her book Women and Gender in Early Modern Europe, Wiesner argues that claustration was mostly oppressive for women religious. She writes that the reforms of the fifteenth century which sought to strengthen adherence to strict claustration were negative because they decreased the contact between nuns and the outside world. ${ }^{16}$

While it is true that some women found this way of life to be burdensome and unfulfilling, Wiesner's emphasis on the imposition of claustration by male clerics and the restrictive nature of claustration causes her to ignore instances of women actively seeking to live their lives in seclusion from the secular world. Furthermore, Wiesner discusses the increased efforts to ensure claustration as a purely masculine attempt to control female sexuality. ${ }^{17}$ This statement implies that women were entirely at the mercy of their male superiors and that nuns had little or no role to play in the enforcement of strict enclosure. Wiesner argues further that the enforcement of strict claustration was difficult

\footnotetext{
${ }^{15}$ Ibid., 113.

${ }^{16}$ Merry E. Wiesner, Women and Gender in Early Modern Europe (Cambridge: Cambridge University Press, 2000), 117.

${ }^{17}$ Ibid., 231 .
} 
because nuns "either fought it or ignored it."18 Though some women opposed the new decree and struggled against its enforcement, Wiesner chooses to discuss only these women.

While I do not deny that male ecclesiastics argued for the claustration of women's religious communities and played significant roles in the enforcement of such standards, I think it is important to acknowledge and analyze the roles that the nuns themselves played in creating cloistered communities. Wiesner, therefore, ignores women like Teresa of Avila who sought to implement stricter claustration in their communities. Contrary to Wiesner, Diefendorf writes that Teresa wanted to "maintain the quiet isolation she believed essential to the cultivation of a deeply interiorized spirituality."19 Furthermore, Teresa's aim was to ensure that the Discalced Carmelite nuns were completely separated from "worldly preoccupations and affections."20 As Rapley points out, "loving testimonials [of the cloistered life] do not prove, by themselves, that every nun was at every time contented with her cloister. But they certainly affirm that there were some, and possibly many, who were." ${ }^{21}$

Although her discussion of claustration focuses mostly on its imposition by men, Penelope Johnson acknowledges that "enclosure could have a positive meaning for the individual nun" and that "records left by the lives of extraordinary women suggest that some of them eagerly sought the structure of a cloistered life."22 Rapley suggests that "whether by choice or necessity, the cloister was the place where these women were

\footnotetext{
${ }^{18}$ Ibid.

${ }^{19}$ Diefendorf, From Penitence to Charity, 112.

${ }^{20} \mathrm{Ibid}$.

${ }^{21}$ Elizabeth Rapley, A Social History of the Cloister: Daily Life in the Teaching Monasteries of the Old Regime (Montreal: McGill-Queen's University Press, 2001), 118.

${ }^{22}$ Penelope Johnson, Equal in Monastic Profession: Religious Women in Medieval France (Chicago: The University of Chicago Press, 1991), 161.
} 
going to spend their lives, and it was up to them to decide whether they would do so as prisoners or as true lovers of Jesus Christ." ${ }^{, 23}$ Cloistered nuns had the ability, the freedom, to choose how they would understand their lives within the convent. Writings of the Carmelites of Beaune further indicate that many cloistered nuns enjoyed their seclusion and as I will explore in later chapters, they found ways to make their claustration meaningful by seeing themselves as members of the Holy Family, identifying with Mary, Joseph and the infant Jesus who lived in seclusion in the crèche and in Nazareth. Few scholars have asked what claustration actually meant to religious women but by studying the spirituality of cloistered nuns, historians can gain insight into the meaning and significance of claustration in the lives of nuns. This is in part what this thesis seeks to explore.

\section{Discalced Carmelite Studies}

Although there are a few substantial studies of the Discalced Carmelites of France, none take as their primary subject matter the spirituality and devotional lives of the nuns themselves. Two works form the foundation for studying the Discalced Carmelites of France. Stéphane-Marie Morgain's 1995 book, Pierre de Bérulle et les Carmélites de France: la querelle du government, 1583-1629, discusses the debates and conflicts leading up to the introduction of the order into France as well as the subsequent foundation of the Carmelite convents and the complex relationship between Bérulle and the order. Le Carmel de Beaune, 1619-1660 by Jacques Roland-Gosselin, published in 1969 , traces the history of the convent by focusing on important individuals, particularly influential nuns, and the spirituality of devotion to the infant Jesus that develops within

\footnotetext{
${ }^{23}$ Rapley, A Social History of the Cloister, 117.
} 
its walls. Another important contribution to the study of the Discalced Carmelites in France is Bernard Hours's 1997 edited collection of articles entitled Carmes et Carmélites en France du XVIIe siècle à nos jours. ${ }^{24}$ Within this collection, articles by Frédéric Meyer, Christian Renoux, Madeleine Foisil and Éric Suire explore the beginnings of the order in France and the seventeenth-century debates involved in the introduction of the Discalced Carmelite nuns into France. ${ }^{25}$ These studies can be roughly organized into two categories: those that address the topic by considering France as a whole, and those that focus on significant figures involved with the Carmelites. The following discussion will address these two themes in the historiography and end with a brief assessment of Roland-Gosselin's book which focuses solely on the Beaune convent. Other than the work of Roland-Gosselin and Frederic Meyer, who focuses on Southern France, all of the other writings of the Discalced Carmelites focus on France more generally. While this offers a more global view of the order, such studies risk overlooking the peculiarities of each region or even of each convent. Of course it would be an arduous task to document the history of each Carmelite convent in France, but perhaps more effort should go into looking into regional groupings of convents as a means of understanding the ways in which the Discalced Carmelite order existed and adapted within local environments. Roland-Gosselin and Meyer have begun to study the Carmelites in this way by focusing on either one particular convent or on a particular

\footnotetext{
${ }^{24}$ Bernard Hours, ed., Carmes et Carmélites en France du XVIle siècle à nos jours (Paris: Les Éditions du Cerf, 1997).

${ }^{25}$ See the following essays in Hours, ed., Carmes et Carmélites en France: Frédéric Meyer, "Carmélites et laïques dévots: l'example des fondations comtadines," 7-18; Christian Renoux, "Madame Acarie 'lit' Thérèse d'Avila au lendemain de l'édit de Nantes," 117-154; Madeleine Foisil, "La figure de Madame Acarie, Marie de l'Incarnation, à travers l'historiographie du XVIIe au XIXe siècle," 155-170; Éric Suire, "La sainteté Carmélitaine, d'après la littérature hagiographique des XVIIe-XVIIIe siècles," 171-189.
} 
region of France. In doing so, each author contributes to our understanding of the nature and operation of these specific religious houses.

Morgain's study considers a broader geographical space and explores the relationship between Pierre de Bérulle and the Carmelites of France. At times, Morgain briefly discusses matters of spirituality, but the devotions of the Discalced Carmelites do not meaningfully factor into his analysis. Rather, his concern is the struggles and conflicts involved in the governance of the order throughout France. Since he applies himself to the study of how the order came to France and all that was involved in the administration and practical aspects of establishing convents, Morgain's broad geographical framework is suitable. His work is thorough and addresses many issues regarding the establishment and ecclesiastical administration of the Discalced Carmelites in France. And although it is an indispensable read for anyone interested in studying the Carmelites of France, it is unfortunate that the spiritual aspects of the order's introduction and success in France are not taken into account.

The work of Christian Renoux and Madeleine Foisil focus entirely on Madame Acarie, the woman considered largely responsible for bringing the Discalced Carmelites to France. Acarie was involved in the Ligue Parisienne which saw its defeat against the Protestants in 1594. Her home became a centre for spiritual discussion and notable figures such as Pierre de Bérulle and Vincent de Paul were frequently in attendance. Through reading the works of Teresa of Avila, published in French in 1601, and receiving visions of the saint asking her to introduce the Carmelites to France, Acarie began her pursuit to establish these nuns in France. Renoux's analysis of the impact of the writings of Teresa of Avila on Madame Acarie adds another dimension to our 
understanding of the impetus for bringing the Discalced Carmelites to France. Additionally, some aspects of spirituality are discussed, in terms of ways in which reading Teresa of Avila's writings impacted Acarie's own spirituality which in turn influenced her involvement in the introduction of the Carmelites in France.

Foisil's article analyzes biographies and the scholarship on Madame Acarie for the seventeenth to the nineteenth centuries. As with the work of Renoux, Foisil offers insight into an important figure of the history of the Carmelites in France. This heightens our understanding of Acarie and how she was understood by later generations of scholars. Focusing on the role of significant figures offers a particular perspective on the introduction of the Carmelites in France; however the dominance of these kinds of studies in the historiography ignores other topics of importance, such as what happened in the lives of the nuns who lived in these convents. Studies concerning France as a whole and those that emphasize the role of certain individuals are necessary components of the study of the Carmelites of France, but it is my hope that in the future, scholars will consider the inner-workings of the convent and the lives of the nuns within, including their distinct spirituality.

Roland-Gosselin's book dedicated to the study of the Beaune convent focuses entirely on the Carmelites of Beaune and therefore demands more careful attention. This is the only monograph to take the Beaune convent as its primary subject. A few articles have touched upon one aspect or another of this convent, but none have ventured so far as to attempt a full study of its foundation and the new devotion to the infant Jesus that developed within its walls. ${ }^{26}$ Morgain dedicates a chapter to the life of Marguerite du

\footnotetext{
${ }^{26}$ Examples of articles that discuss the Beaune convent include Cynthia Cupples, “"Plus que l'exemple de ses saintes vertus': Catholic Women and the Communication of Relics in Seventeenth-Century France,"
} 
Saint Sacrement and subsequent chapters emphasize her role in the Beaune convent, particularly regarding the devotion to the infant Jesus. In this regard, Roland-Gosselin's work is very helpful in contextualizing the particular ways in which the Discalced Carmelites practiced their devotion to the infant Jesus. Roland-Gosselin provides an introduction into the origins of the development of the devotion to the infant Jesus at the Beaune convent, connecting Bérulle's spiritual influence, that of Dijon (the convent that founded the Beaune convent), and the life and role of Marguerite du Saint Sacrement under whose influence the devotion to the infant Jesus flourished.

In this way, Roland-Gosselin's book is an extremely important contribution to the historiography. On the other hand, although he discusses the spiritual aspects of the convent, linking them to broader external influences, Roland-Gosselin's analysis of the devotion to the infant Jesus focuses almost entirely on Marguerite du Saint Sacrement. Although her influence and importance in spreading this devotion must not be underestimated or ignored, I would argue that the focus should shift. Scholars need to analyze the practice of this devotion among the Carmelites of Beaune more generally. It is admittedly difficult to ascertain the experiences and thoughts of all of the individual nuns, especially since many of the primary sources from the convent reflect this same focus on Marguerite. Although many of the sources that I analyze in this thesis are related to Marguerite, such as letters and accounts of her interactions with the infant Jesus, I would like to venture beyond a discussion of Marguerite's devotion to the infant Jesus and attempt to study the kinds of devotional behaviours that were practiced at

Proceedings of the Western Society for French History, 31 (2003): 17-32; Cynthia Cupples, “'Between You and Us': Nuns and Spiritual Discernment in Seventeenth-Century France," Proceedings of the Western Society for French History, 33 (2005): 114-130; and Jacques Marx, "Marguerite du Saint Sacrement, le roi et le petit Jésus," Revue belge de philologie et d'histoire 83 (2005): 1133-1154. 
Beaune. While accounts and experiences of Marguerite are important in such a study I hope to demonstrate that the piety and spirituality of the convent as a whole was centred upon devotion to the infant Jesus, particularly through the imitation of Mary and her son. I intend to follow the kind of thinking exhibited by Roland-Gosselin, connecting Bérulle, the école française and the Beaune convent, in order to explore the devotion to the infant Jesus in more depth. Roland-Gosselin's contribution to the field is a step in the right direction and I hope that others will go further in exploring the various aspects of Discalced Carmelite spirituality, whether in the Beaune convent or elsewhere.

\section{Marian Devotion and Imitation}

Since a critical section of this study concerns Marian devotion and imitation, it is necessary to spend some time exploring the scholarship in this area. Many authors explore the role of Mary in medieval and early modern Catholicism, but few discuss the imitation of Mary. A search for studies of Marian veneration and imitation among nuns, even the Discalced Carmelites who were particularly devoted to her, presents even fewer sources, since no scholar, as least that I have found, has taken on this task. Nonetheless, a few scholars have tackled the subject of Marian devotion and their work is important for this thesis. The work of Donna Spivey Ellington, Marina Warner, Carolyn Walker Bynum, and Rosemary Hale inform my analysis of Marian imitation among the Carmelites of Beaune.

Donna Spivey Ellington's book, From Sacred Body to Angelic Soul, explores Mary's motherhood in detail. Ellington argues that a shift occurred during the sixteenth century when the Catholic Church focused less on Mary's body, and more on her soul 
and inner spirituality. ${ }^{27}$ According to Ellington, because Mary's soul was considered more important than her body, her spiritual motherhood of Christ was more important than her physical motherhood. ${ }^{28}$ This emphasis on Mary's soul has important implications for my analysis of the ways in which the Carmelites of Beaune were to see Mary as a model of motherhood, particularly because I consider both the physical and mental ways in which the nuns imitate Mary's motherhood.

If one accepts Ellington's argument that early modern understandings of Mary's motherhood favoured her spiritual relationship with Christ rather than the physical relationship, it may be easy to see how the Discalced Carmelites of Beaune were called to be imitators of Mary. Since they were unable to become earthly, biological mothers due to their solemn and perpetual vow of virginity, the Discalced Carmelites, if they were to be mothers, could do so only in a spiritual way. This conclusion would fit nicely with Ellington's argument and would clearly distinguish medieval and early modern devotional practices. But the maternal imagery, vocabulary, prayers and behaviours of the Carmelites of Beaune do not correspond with Ellington's medieval-early modern divide. Upon analyzing the sources from the convent in Beaune, one finds a more complex set of ideas and devotional practices which include an emphasis on both the spiritual and physical aspects of Mary's maternity. They likewise encourage mental contemplation and physical imitation of Mary's motherhood and her relationship with the infant Jesus. Rather than using Ellington's physical-spiritual divide, I will speak of a more internal-external or thought-action divide, although as a later chapter will demonstrate, this divide is not always evident, nor does it necessarily exclude devotions

\footnotetext{
${ }^{27}$ Donna Spivey Ellington, From Sacred Body to Angelic Soul: Understanding Mary in Late Medieval and Early Modern Europe (Washington: The Catholic University of America Press, 2001), viii.

${ }^{28}$ Ibid., 174.
} 
that are both thought and action oriented. In fact many of the Carmelite devotions hinge on the intersection of mental contemplation and physical behaviour.

Marina Warner's monograph, Alone of All Her Sex: The Myth and Cult of the Virgin Mary, is not a typical historical analysis of Marian devotion. ${ }^{29}$ In fact, Warner explicitly states that her work is not a history of the cult of the Virgin, but rather, by structuring her book thematically, addressing the various facets of Mary and working backwards and forwards in time, Warner seeks to discuss the ideas that contributed to all aspects of understandings of Mary. In doing so, she considers Mary as virgin, queen, bride, mother and intercessor. Although Warner's work does not heavily inform this thesis it is important to acknowledge her contribution to the study of Marian devotion more generally. Despite the fact that her book is not a historical analysis, Warner's work has nonetheless influenced historical studies of the subject.

Caroline Walker Bynum's analysis of Marian devotion is more general in scope, addressing the Virgin Mary when relevant. Her book Holy Feast and Holy Fast: The Religious Significance of Food to Medieval Women, though focused on the medieval period, makes an important contribution to understandings of early modern perceptions and interpretations of the Virgin Mary. Focusing her study on women in particular, Bynum has much to say about the significance of the devotional practices of nuns. The most important aspect of her work is the way in which she analyzes the relationship between Mary and Christ, both physically and spiritually. Of particular interest is Bynum's discussion of the relationship between Mary and the Eucharist and the significance of this to female spirituality. Bynum explains how Mary was commonly

\footnotetext{
${ }^{29}$ Marina Warner, All Alone of Her Sex: The Myth and the Cult of the Virgin Mary (New York: Alfred A. Knopf, 1976).
} 
associated and revered for her relationship with Christ. As Christ's mother, Mary contained him in her womb and from her Christ was born, therefore generating a particular physical relationship between them. ${ }^{30}$ According to medieval women such as Hildegard of Bingen, Mechtild of Magdeburg and Catherine of Siena, Mary, by giving birth to Christ, was the vehicle through which humanity took on flesh. In this framework, Christ's flesh was also considered, in a sense, female, because he shared in the flesh of his mother. ${ }^{31}$ Bynum goes further to relate the physical connection between Mary and Christ to the Eucharist. Later we will see the ways in which Eucharistic imagery and the physical relationship between Mary and Christ is exhibited in the sources from Beaune and the ways in which the Discalced Carmelites mimic Mary's physical reception of Christ by receiving the Eucharist.

One of the most important scholars for this analysis is Rosemary Hale, whose doctoral dissertation and subsequent articles are indispensable for understanding the practice of imitatio Mariae among the Discalced Carmelites of Beaune. ${ }^{32}$ Not only does she address Marian devotion and veneration, but she focuses specifically on the imitation of Mary's motherhood and her work offers a new way of thinking about the imitation of Mary's maternity. Of all of the scholars considered here, she is the most directly pertinent to the study of the Discalced Carmelites' imitation of Mary's motherhood and the ways in which they interact with the infant Jesus.

\footnotetext{
${ }^{30}$ Ibid., 267.

${ }^{31}$ Ibid., 265.

${ }^{32}$ Rosemary Hale, "Imitatio Mariae: Motherhood Motifs in Late Medieval German Spirituality" (PhD diss., Harvard University, 1992), "Imitatio Mariae: Motherhood Motifs in Devotional Memoirs," Mystics Quarterly 16 (1990): 193-203, and "Rocking the Cradle: Margaretha Ebner (Be)Holds the Divine," in Performance and Transformation: New Approaches to Late Medieval Spirituality, eds. Mary A. Suydam and Joanna E. Ziegler (New York: St. Martin's Press, 1999), 211-239.
} 
Hale's work focuses on the imitation of Mary's motherhood in late medieval German spirituality. She analyzes in detail the imitatio Mariae of German nuns such as Margaretha and Christine Ebner. Although she studies a medieval German context her exploration of female religious behaviour is useful as it provides historical precedent for the behaviour of the seventeenth-century Carmelites of Beaune. The behaviour or performance of imitatio Mariae forms the focus of Hale's analysis of the ways in which women understood Mary's maternity, her relationship with the Christ Child and how they could actually become Mary. In her doctoral dissertation Hale explains how she applies recent studies in performance theory to her analysis of late medieval imitatio Mariae. For her, imitation is by nature performative, that is "in order to imitate the behaviour of a particular religious model, the worshipper must do something, perform some activity in imitation." 33 This conceptualization of the behavioural imitation of Mary is useful in my analysis of the ways in which the Discalced Carmelites mimic Mary's maternity. While Hale focuses on the physical imitation of Mary, that is, actually performing specific activities such as kissing, embracing and cradling she stops short of considering the more interior ways in which the nuns seek to imitate Mary. My work attempts to address both the external, behavioural imitation of Mary's motherhood as well as the ways in which the Carmelites of Beaune mimic Mary in a more contemplative way, by thinking, imagining and spiritually uniting themselves with her feelings and thoughts.

Despite this difference between Hale's work and this study, her analysis of the performance of maternal affection among cloistered women is exceptionally useful in trying to understand the very similar practices of the Carmelites of Beaune. Hale discusses female visionaries' experiences of seeing the infant Jesus and his mother and

${ }^{33}$ Hale, "Imitatio Mariae: Motherhood Motifs in Late Medieval German Spirituality," 18. 
their experiences of holding, caressing and even nursing the Christ Child. Though I have found no instances of the Discalced Carmelites nursing the infant Jesus, there is an abundance of references to performing maternal affection by holding, kissing, and caring for him. Hale's studies of such experiences and behaviours in the medieval period are fascinating and provide a relevant historical context within which to analyze the nature of imitatio Mariae in the seventeenth century. Moreover, Hale's work offers a vocabulary and way of understanding imitatio Mariae that is invaluable for my analysis.

\section{The Infant Jesus and the Imitation of Christ}

Just as recent scholarship pertaining to Marian devotion and imitation is important for this study, so too is the historiography regarding the infant Jesus and the imitation of Christ. I group these two subjects together since they are interrelated in my analysis, for the Discalced Carmelites performed imitatio Christi through the imitation of the infant Jesus. Since this thesis is centred upon the devotion to the infant Jesus, it may seem strange that the following section is as short as it is. While we know something of the development of this spirituality, as Chapter One explores, I do not think we can speak of a historiography of the devotion to the infant Jesus. Despite the significance of this devotion in seventeenth-century French spirituality, it has received little scholarly attention. Even though devotion to the infant Jesus was present, albeit in a different form and accompanied with different practices in the medieval period, historians of this era also seem to have largely overlooked this aspect of Christian piety. Of course many works dedicated to medieval religious practices, and even some from the early modern period, mention or briefly touch upon the Christ Child, but such references are difficult to 
find, as they are entrenched within studies of a different topic. Moreover, few studies have focused primarily on the devotion to the infant Jesus. Similarly, although the imitation of Christ is a significant aspect of Christianity and was indeed present among believers since the beginning of Christian history, studies dedicated to the history of the imitation of Christ and the various ways it was understood and practiced are largely lacking. The following will discuss a few authors who have tackled these subjects while demonstrating the need for further historical inquiry and analysis in these areas.

In her doctoral dissertation Mary Dzon explores the image of the Christ Child in late medieval legends. ${ }^{34}$ Although, like Hale, she focuses on medieval perceptions and practices, her analysis is useful as it contributes to the history of the devotion to the infant Jesus. Chapter four of her dissertation is most relevant to this thesis as it discusses the imitation of the Christ Child. Despite its brevity, this section analyzes the ways in which the imitation of the Christ Child was understood in the medieval period. Dzon writes that individuals could imitate the infant Jesus spiritually by imitating his virtues, something that is also present among the Carmelites of Beaune. On the other hand, Dzon writes that the imitation of the Christ Child was "perilous" and that in some instances it was even considered "dangerous." 35 Though such perceptions of the imitation of Christ are not present amongst the Discalced Carmelites, Dzon's analysis of their existence during the medieval period contributes to our understanding of the changes in how individuals understood and practiced imitation of the infant Jesus.

Giles Constable's chapter on "The Ideal of the Imitation of Christ" in his book Three Studies in Medieval Religious and Social Thought offers an analysis of the various

\footnotetext{
${ }^{34}$ Mary Dzon, "The Image of the Wanton Christ-Child in the Apocryphal Infancy Legends of Late Medieval England" (PhD diss., University of Toronto, 2004).

${ }^{35}$ Ibid., 244-252.
} 
facets of the imitation of Christ during the Middle Ages. ${ }^{36}$ He considers the imitation of Christ's divinity, humanity and his body, all of which are involved in the Discalced Carmelite imitation of the infant Jesus. Constable considers the various ways in which people understood and practiced the imitation of Christ in the medieval period, through different understandings of who Christ was: divine and yet human. Constable's discussion of the ways in which medieval individuals negotiated the imitation of Christ's divinity and his humanity help in understanding how the Discalced Carmelites of Beaune wrestled with the same issue. Constable explains the twelfth-century devotion to Christ's infancy and the emphasis on his humanity, themes that are evidently central to Discalced Carmelite spirituality.

Despite its relevancy to this thesis in terms of providing a historical context for studying the seventeenth century, Constable's work, like that of Hale, Dzon and Bynum, deals with the medieval period. Little, if anything, has been done regarding the early modern devotion to the infant Jesus and the imitation of Christ. No major work tackles this subject. Scholars of the medieval period have explored the subject of devotion to the infant Jesus, the imitation of Christ, as well as Mary's motherhood, but studies are lacking for the early modern period. By exploring these themes as they are understood and practiced by the Discalced Carmelites of seventeenth-century Beaune, I hope to analyze the ways in which these devotions were adapted and formed an essential part of seventeenth-century French spirituality.

\footnotetext{
${ }^{36}$ Giles Constable, Three Studies in Medieval Religious and Social Thought (Cambridge: Cambridge University Press, 1995).
} 


\section{Defining a Period: Early Modern Catholicism}

Most historians have realized that the way in which we temporally frame our analyses and the terms we use to designate historical periods require definition and justification. While I do not intend to provide a lengthy or exhaustive account for the terms we use to designate what is commonly referred to as the early modern period, I do think it is important to spend some time indicating what I mean by the temporal terms used in this thesis and how I understand the period I am studying. This is also a means of explaining my decision to focus on the seventeenth century, specifically 1619-1700.

It is important to understand what we mean when we discuss the early modern period, specifically when discussing the Catholic Church. A number of terms have been used to denote this period in the history of the Catholic Church: Catholic Reformation, Counter Reformation, Catholic Renewal, post-Tridentine era, etc. Additionally, scholars have used other terms to characterize the seventeenth century in France in particular, such as "le grand siècle." John O'Malley has done much to heighten our awareness and understanding of how we characterize and define this period. In Trent and All That: Renaming Catholicism in the Early Modern Era, O'Malley provides a historiographical summary of historians' naming of the "Catholic side" of the Reformation and early modern Europe more generally. ${ }^{37}$ Additionally, O'Malley offers a new term for this period: early modern Catholicism. O'Malley explains the difficulty with defining Catholicism in the early modern period. Some see Catholicism of this period as a reaction to the Protestant Reformation, others argue that the Catholic Church was already in a process of change before the Reformation, while still others suggest a combination of

\footnotetext{
${ }^{37}$ John O'Malley, Trent and All That: Renaming Catholicism in the Early Modern Era (Cambridge, Mass.: Harvard University Press, 2000).
} 
these two perspectives. It is partly due to this complexity that historians have employed a variety of terms to denote Catholicism of the sixteenth, seventeenth and sometimes even eighteenth centuries.

O' Malley offers three suggestions in the face of the dilemma of what to call Catholicism of the early modern period. First, he suggests that we accept the multiplicity of names as a good thing. Secondly, O' Malley advocates a more reflective use of these terms, which often refer to only one aspect of early modern Catholicism, so as to, as he says "avoid taking a part for the whole." Lastly, O'Malley recommends adding the term "early modern Catholicism" to our vocabulary. ${ }^{38}$ I agree with O'Malley's assessment that many of the terms we use to name Catholicism in the early modern period refer to particular aspects or reflect particular ways of thinking about the Catholic Church at this time. While all names imply a certain amount of judgement and understanding of meaning, the term early modern Catholicism is more inclusive and broader than the other terms used. Significantly, O'Malley does not argue for the exclusion or discontinuation of other terms such as Catholic Reformation, Catholic Renewal, confessionalization, post-Tridentine era, etc. What O'Malley has done for historians is critically assess the terms we use and the ways in which we, for the most part, carelessly apply these terms to Catholicism of this period. Aside from his contribution of yet another name for Catholicism of the early modern period, I think O'Malley's greatest contribution is his call to historians to be more reflective and conscious of the words we use and the meaning they carry.

Moreover, O'Malley's analysis of the ways in which historians have studied early modern Catholicism is also important. Until approximately sixty years ago, historians

${ }^{38}$ Ibid., 125. 
tended to study early modern Catholicism by looking at the Catholic Church as an institution and the hierarchy of its members: papacy, bishops, priests, and to a much lesser extent (if at all), religious orders. With the exception of Henri Brémond's Histoire littéraire du sentiment religieux, translated into English in 1936, it was not until $\mathrm{H}$. Outram Evennett's 1951 lectures on spirituality, published in 1968, that some historians began to take a different approach to the study of early modern Catholicism. ${ }^{39}$ Evennett argued for "the incorporation into church history of the history of spirituality or piety" as well as for "a similar coordination of church history with secular history-that is, not treating church history in an ecclesiastical/doctrinal vacuum. ${ }^{, 40}$ This led a number of scholars to pursue the subject of "religious sentiments", to use the words of Lucien Febvre. ${ }^{41}$ Historians such as Etienne Delaruelle, Gabriel Le Bras, Jean Delumeau, Louis Châtellier and John Bossy often take as their subject not church history strictly speaking, but the history of practising Christians, that is, the religious practices of men and women which have often been overlooked and did not factor into previous explorations into early modern Catholicism. ${ }^{42}$ In this way, this thesis is broadly indebted to such scholars who paved the way for studies of religious belief and behaviour. O'Malley states that "historians must therefore study religion, not churches, if they hope to understand the sixteenth century." ${ }^{43}$ I would extend this statement to include attempts at understanding the seventeenth-century as well.

\footnotetext{
${ }^{39}$ Ibid., 73.; H. Outram Evennett, The Spirit of the Counter-Reformation (Cambridge: Cambridge University Press, 1968).

${ }^{40}$ O'Malley, Trent and All That, 74.

${ }^{41}$ Ibid., 95.

${ }^{42}$ See Jean Delumeau, Catholicism Between Luther and Voltaire: A New View of the Counter-Reformation (London: Burns and Oates Limited, 1977); Louis Châtellier, Le Catholicisme en France, 1500-1650, (Paris: Sedes, 1995) and Louis Châtellier, L'Europe des dévots (Paris: Flammarion, 1987).

${ }^{43}$ O'Malley, Trent and All That, 95.
} 
So what implications does this have for the current study? First of all, since this thesis deals with the early modern period and early modern Catholicism in particular, O’Malley's discussion of periodization is relevant. Historians often have to make difficult decisions in terms of when they consider the beginning and end of the early modern period. O'Malley writes that some frame their discussions of early modern Europe sometime between the Great Schism and the French Revolution, others begin with 1517 as the beginning of the Protestant Reformation and end in 1648, and still others extend the period to include the fifteenth through eighteenth centuries. For the purposes of this thesis, defining the entirety of the early modern period is less important, as I do not purport to provide a history of the Discalced Carmelites or of the devotion to the infant Jesus throughout the early modern period, but it is important to make clear that the years under review in this thesis fit into almost all conceptualizations of early modern Europe. Few historians, I think, would argue that the temporal parameters of this thesis do not fit into early modern European history.

My choice to focus on $1619-1700$ is largely practical. The convent of the Discalced Carmelites of Beaune was founded in 1619 and since my thesis focuses on the nuns of this monastery, 1619 was an obvious choice. The end date of my analysis is less significant and more approximate. In part I wanted to contain my analysis within the seventeenth-century, considering the peculiarities of France and its Catholic spirituality of this time. Additionally, I wanted to use sources from the time that Marguerite du Saint Sacrement was living at Beaune (1619-1648) and those from shortly after, as the devotion to the infant Jesus continued to thrive after her death. The sources at my disposal from the Beaune convent date from 1619-1697 and so the end of the seventeenth-century 
seemed to be a good terminal date. Of course one could continue to trace the history of the devotion to the infant Jesus throughout the eighteenth century, even until the present, but this was never my intention. From the beginning, I intended to stay within the seventeenth-century and analyze sources, individuals, Catholic ideologies, beliefs and practices during this time.

As far as my use of terms for early modern Catholicism, I, like many historians, frequently fall into unreflectively using terms. Like O'Malley, I think that the multiplicity of names for Catholicism of this period can be a good thing, as each term, when used intentionally and for a purpose, can convey the particular meaning intended by the author. Throughout my thesis I will use a variety of terms, but only after some thought regarding the emphasis I intend to make with each statement. Admittedly, at times the multiplicity of names used to denote this period are used primarily for variety of terminology and to avoid repetition.

\section{Conceptual Considerations: Imitation, Performance and Ritual}

As with many studies of religious behaviour, this thesis deals with concepts such as imitation, performance and ritual. In this section I will briefly address some theoretical considerations related to my study of the devotion to the infant Jesus among the Discalced Carmelites of Beaune. This will provide a conceptual framework within which we can begin to understand and derive meaning from the devotional behaviours of these nuns.

Much of the theoretical and conceptual foundation of this study stems from the work of Rosemary Hale whose research on the imitation of Mary's motherhood centres 
upon ideas of performing imitatio through physical action. Since her work so closely resembles this thesis, the way in which she approaches the study of imitatio Mariae is very useful as it offers a language with which to explain and attempt to understand the ways in which the Discalced Carmelites of Beaune embodied and performed their acts of devotion to the infant Jesus. Hale defines imitation (or imitatio) as a term referring "to modeling behaviour based upon what is known of the lives of holy persons paradigmatic for any particular religious tradition. Biographical details," she continues, "drawn from the lives of holy figures provide the basis for, and shape the content of, imitatio performances." ${ }^{44}$ Hale further states that "imitation involves impersonating or mimicking the attributes or conduct of a paradigmatic holy person, a religious figure held in high regard." ${ }^{, 45}$ As we will see later, events from the lives of Mary, Joseph and the infant Jesus form the basis of the Discalced Carmelites' imitation of the life of the Holy Family. The nuns mimic and attempt to mirror their lives on those of Mary, Joseph and the infant Jesus through certain behaviours as well as mental and emotional exercises.

This is where Hale's definition or use of the term imitation has limited application for this thesis. Hale speaks of the imitation of physical behaviours, of action, which involve bodily manipulation. Indeed, she states that "imitation is only observable in behaviour, through the actual performance of the imitatio." ${ }^{46}$ While it may be difficult to ascertain one's imitation of an individual in the absence of "observable behaviour," it does not mean that individuals did not seek to imitate the thoughts and emotions of holy people. Throughout the Beaune documents, the Discalced Carmelite nuns are encouraged to mimic the feelings and mental activities of Mary, Joseph and the infant Jesus. While it

\footnotetext{
${ }^{44}$ Hale, "Imitatio Mariae: Motherhood Motifs in Late Medieval German Spirituality," 14.

${ }^{45}$ Ibid., 15.

${ }^{46}$ Ibid.
} 
is difficult to determine the extent to which the nuns actually did this, it is nonetheless important to include in our definition of imitation the mimicking of an individual's interior dispositions, their thoughts and feelings. Perhaps this is merely a reflection of the difference between this thesis and the work of Hale: she analyzes the writings of nuns and the ways in which they express their experiences with the infant Jesus and their physical imitation of Mary's motherhood, while I seek to explore the ways in which the Discalced Carmelites of Beaune were encouraged to imitate the members of the Holy Family and the nature of the distinct spirituality of the Beaune convent. I attempt to go deeper into the devotion to the infant Jesus and analyze the mental and physical imitation of Mary, Joseph and the infant Jesus.

Despite this difference between our uses of the term imitation or the kind of imitation that we explore, Hale's conceptualization of the behavioural performance of imitatio provides a foundation for understanding the physical actions of imitation among the Carmelites of Beaune. Hale writes that the through the performance of imitatio "the worshipper imitates specific postures, mannerisms and demeanours of the model; dresses like the model and mimics the way in which the model represents or relates to the divine. Overall the worshipper acts like the person being imitated." 47 When the Carmelites cradle, rock, embrace or kiss the infant Jesus, they are mimicking Mary's behaviour towards her son. Thus, the nuns act in the same way Mary did towards the infant Jesus by imitating her maternal displays of affection.

Hale makes an important distinction between imitation and veneration. She writes that "veneration does not rely exclusively on imitative practices. Imitation is founded upon the admiration; hence, it is a form of veneration. Nevertheless, it is only

${ }^{47}$ Ibid. 
one of the many forms of venerative behaviour. One can venerate...without imitation."48 Mary, Joseph and the infant Jesus are venerated, that is, adored and honoured, due to their proximity to the divine, their role in salvific history, and their admirable qualities, but this does not necessarily lead to imitation. As Hale states, imitation is a form of veneration but there are a number of other ways in which individuals can venerate the divine or a holy person, for example through prayers or hymn singing. So when the Discalced Carmelites of Beaune imitate Mary's maternal behaviour towards the infant Jesus, or when they imagine themselves suffering as Christ did, they are performing acts of imitation. Hale states this very clearly when she writes that "only when the paradigmatic model...furnishes the palette for religious behaviour is it imitatio." ${ }^{, 49}$

When we speak of religious behaviour, whether it is prayers said silently or aloud, the veneration of a statue, the singing of a hymn or the imitation of a prominent religious figure, we speak of performance. That is, any religious behaviour is essentially performative. The performance of religious behaviour, including that of imitation, involves a behaviour and an audience. As I mentioned earlier, this thesis explores the mental and physical imitation of the Holy Family and therefore, some forms of imitation among the Discalced Carmelites of Beaune are less obviously performative in that they may not always accompany a clear, physical action. Nonetheless, their internal or mental imitation of Mary, Joseph or the infant Jesus can still be considered performative, even if it is only for themselves or for a divine audience. ${ }^{50}$ Hale writes that "imitatio naturally falls into the descriptive category of performance. In order to imitate the behaviour of a particular religious model, the worshipper must do something, perform some activity in

\footnotetext{
${ }^{48}$ Ibid., 16.

${ }^{49}$ Ibid., 17.

${ }^{50}$ Ibid., 18.
} 
imitation. ${ }^{, 51}$ While I generally agree with this assessment, I argue that when it comes to imitating an individual's mental or emotional state, the performative aspect of imitation is less clear. While I believe that the Discalced Carmelites " $d o$ something" when they mimic Mary, Joseph or the infant Jesus' feelings or interior dispositions, the mental activity is less obvious and certainly less visible than a physical act of imitation. Nonetheless, this form of imitative behaviour is performative, in the sense that they actively do something, even if it remains internal, for an audience, even if that audience is God alone.

In discussions of religious performances of imitation, the concept of ritual must necessarily be addressed, for such imitative behaviours are often closely linked with ritualistic actions. In his book Ritual in Early Modern Europe, Edward Muir writes of the difficulty of defining the term ritual. He states that "most theorists would accept that a ritual is a formalized, collective, institutionalized kind of repetitive action" but adds that "there is still a bewildering range of answers to the question, "what is ritual?", 52 For the purposes of this thesis, it is important to consider how the devotional behaviours, specifically those imitative in nature, of the Discalced Carmelites of Beaune can be seen as ritualistic. That is, the prayers and actions of the nuns operate within the framework of the liturgical calendar of the Catholic Church and involve specific, repetitive behaviours, both mental and physical. In this case, we consider the ritualistic nature of religious behaviour in order to understand something of the purpose and meaning of the imitative practices of the Discalced Carmelites of Beaune.

\footnotetext{
${ }^{51}$ Ibid.

${ }^{52}$ Edward Muir, Ritual in Early Modern Europe (Cambridge: Cambridge University Press, 1997), 3.
} 
After suggesting a variety of ways in which scholars understand what rituals are and what they do, Muir writes that the best solution to the confusion over the purpose or role of rituals is Handelman's distinction between "models" and "mirrors."53 Models can be understood as either providing a standard to follow or consisting of a miniature of something. Muir writes that rituals often work like models in that they "present a standard or a simplified miniature...to follow." 54 Contrary to models, mirrors "present the world as it is understood to be. ${ }^{, 55}$ The imitative behaviour of the Discalced Carmelites represents the first kind of ritual, that is, it provides a model for the nuns to follow. Just as the figures of Mary, Joseph and the infant Jesus are models of how to behave, the suggestions or encouragements for precisely what kind of behaviour, contained in the documents from Beaune, offer an array of rituals for the nuns to perform. For example, when a priest writes to Marguerite du Saint Sacrement saying that she must look at an image of Mary with the infant Jesus, asking permission to approach and kiss him just as Mary did, and then to bow down and kiss the child's hand several times, he provides her with a powerful model for behaviour. ${ }^{56}$ Both Mary and the behaviour prescribed constitute models for Marguerite's veneration and adoration of the infant Jesus.

Throughout this thesis I attempt to explain and to make sense of the imitative behaviours of the Discalced Carmelites of Beaune. Understanding concepts such as imitation, performance and ritual aids in this endeavour; however I acknowledge the difficulty of defining the meaning or significance of the devotional lives of these nuns. As Muir writes, "rituals are inherently ambiguous in their function and meaning. They

\footnotetext{
${ }^{53}$ Ibid., 4.

${ }^{54}$ Ibid., 5.

${ }_{56}^{55}$ Ibid.

${ }^{56}$ Marie-Françoise Grivot, ed., Marguerite du Saint Sacrement: Correspondance (lettres reçues à son sujet), vol. 1 (Lanzy: Forelle, 1997), 182-183.
} 
speak with many voices." ${ }^{, 57}$ It may be impossible to ascertain all meaning associated with the imitative behaviours of the Discalced Carmelites of Beaune. However, analyzing the ways in which they sought to create an intimate relationship with the infant Jesus through imitating Mary's motherhood and the infant Jesus himself brings us one step closer to clarifying and understanding the purpose and importance of such thoughts and actions in their lives.

Throughout this thesis the concepts of imitation, performance and ritual will be employed in order to understand what certain behaviours "do" and how they were imagined in early modern Catholicism. In this section I have sought to introduce these concepts as a way to begin thinking about the devotional behaviours of the nuns. An analysis of their ritualistic, imitative behaviour and its role in their devotion to the infant Jesus forms the subject of the following chapters.

\section{A Word on Sources: The Documents from Beaune}

The majority of the sources used in this thesis come from the archives of the Beaune convent currently held in the municipal archives collection in the Hôtel de Ville in Beaune. This collection includes fifty dossiers, some of which contain a variety of documents, while others constitute a single, cohesive document. The nature and content of these documents varies, as this archive includes correspondence between the Beaune convent and the outside world, devotional manuals, fragments of memoires and vitae, books of canticles written by the nuns of Beaune, descriptions of Marguerite du Saint Sacrement's visions of the infant Jesus, etc. The archive was organized into its current

\footnotetext{
${ }^{57}$ Muir, Ritual in Early Modern Europe, 5.
} 
form during the nineteenth century and in fact some of the documents are copies made from the seventeenth-century originals that are now apparently lost.

This vast collection of documents is essential to the study of the Discalced Carmelites of Beaune since it contains most of the remaining sources from the seventeenth-century convent. Moreover, most of the documents relate to Marguerite du Saint Sacrement and the devotion to the infant Jesus. Given the array of sources within this collection there is likewise a variety of authors represented therein. Letters from priests, lay men and women, Discalced Carmelite nuns and those of other religious orders, in addition to devotional manuals and accounts of events written by the abbess are all included in this archive, offering a variety of sources, in terms of content and form, as well as a multitude of voices. One task of this thesis is to critically interrogate these documents and determine their relationship to the Beaune convent in terms of their influence on the devotion to the infant Jesus. Indeed, the primary aim is to discover the ways in which these writings reflect evidence of a particular manifestation and embodiment of this devotion.

After the French Revolution and its devastating effect on religious houses, documents from earlier centuries were often destroyed and those that survived were frequently scattered, finding their way into local libraries where they are often still found. Such is the case with some sources from the Beaune convent. It seems as though not all of the seventeenth-century documents from the monastery were preserved within the archival collection. The municipal library in Beaune, Bibliothèque Gaspard-Monge, currently holds a few printed editions of devotional manuals and a manual for Discalced Carmelite novices, entitled Préparation à la vie religieuse (1664), which is from the 
Beaune convent. ${ }^{58}$ The other two sources found here include Institution de la famille $d u$ saint enfant Jésus (1669) and Le petit office du saint enfant Jésus (1697), both of which include reflections on the devotion to the infant Jesus and a register of prayers to be said on particular days throughout the year. Along with those found in the archives of the convent, these sources have been indispensable for this thesis.

Marie-Francoise Grivot's edition of correspondence to and from the Beaune convent is of equal value. Her four volume collection of correspondence allows the historian to consult the letters travelling to and from the Beaune convent with much more ease than going through the eleven volumes of the original letters found in the convent's archive. ${ }^{59}$ In addition to providing hundreds of letters related to Marguerite du Saint Sacrement, Grivot also provides comments for the vast majority of the letters. In addition to these four volumes of correspondence, Grivot has also edited a separate collection of letters written by and for Marguerite du Saint Sacrement. The comments appended to these letters are also extremely helpful and offer some suggestions and ways of thinking about the content and form of the letters. But before we can delve into these sources and begin to explore the particular nature of the devotion to the infant Jesus that thrived within the Beaune convent, we need to take a moment to understand its historical and spiritual milieu.

\footnotetext{
${ }^{58}$ A handwritten note on the front page of one manual tells us that "ce livre est aux Carmélites de Beaune." ${ }^{59}$ See Beaune, AM, Archives du Carmel, 39, "Correspondance" and Marguerite du Saint Sacrement: Correspondance (lettres reçues).
} 


\section{Chapter One}

\section{Historical and Spiritual Context of Beaune}

At the request of three bourgeois sisters of a prominent Beaunois family, a Discalced Carmelite convent was founded in Beaune in 1619. Their letter to the abbess of the Dijon house requested the establishment of a new convent and soon after, on July 25,1619 , seven nuns from Dijon travelled to Beaune where they established a new Discalced Carmelite monastery. ${ }^{1}$ Despite the order's popularity and growth in France during this time, Beaune residents seemed far from ready to accept yet another group of nuns in their town. ${ }^{2}$ Nonetheless, the convent was indeed founded and even flourished. The nuns gained notoriety for their devotion to the infant Jesus and their intimate relationship with the école française which informed and shaped their distinct spirituality. Additionally, with the new devotion to the infant Jesus the ties between the convent and the laity of Beaune strengthened, creating a dynamic relationship between the cloistered nuns and the devout laity.

The purpose of this chapter is to explore both the material and spiritual context of Beaune during the seventeenth century. This will provide the necessary background and act as an introduction to the world in which the Discalced Carmelites lived and in which their devotion to the infant Jesus developed and flourished. I will explore Beaune's recent history as a means of situating the town in space and time. I will also discuss the founding of the Beaune convent and the relationship between the nuns and the laity, specifically in terms of the origins of the convent and the development of the devotion to the infant Jesus. Moreover, I will provide a brief account of the history of the devotion to

\footnotetext{
${ }_{1}^{1}$ Roland-Gosselin, Le Carmel de Beaune, 30.

${ }^{2}$ Ibid., 28.
} 
the infant Jesus. I will also explore the relationship of the Beaune convent with the école française, a distinct school of Catholic spirituality in France during the seventeenthcentury. This religious context is essential to understanding the particular spirituality of the Beaune convent. The new devotion to the infant Jesus did not develop in a vacuum, but rather grew alongside contemporary French Catholic piety.

\section{Seventeenth-Century Beaune: Recent History}

Since this thesis focuses explicitly on the Discalced Carmelite convent in Beaune, it is useful to offer a brief recent history of the town in order to situate the seventeenth century spirituality within a broader historical context. Of utmost importance for understanding the historical milieu of the devotion to the infant Jesus among the Discalced Carmelites of Beaune is the religious conflict of the sixteenth and seventeenth centuries. The Wars of Religion manifested through the animosity and violence between Catholics and Calvinists influenced the evolution of both confessions throughout the seventeenth century. By looking specifically at the nature of these conflicts in the Burgundy region and Beaune in particular, we gain insight into the historical context within which the Discalced Carmelite convent existed and the devotion to the infant Jesus developed.

Sixteenth-century Beaune, as elsewhere in France, experienced first hand the Wars of Religion between Protestants and Catholics. An overwhelmingly Catholic town, Beaune was frequently attacked or under threat of attack from Protestant forces. ${ }^{3}$ There was great concern of allowing "heresy" in the form of Calvinists into Beaune, and

\footnotetext{
${ }^{3}$ M. Rossignol, Histoire de Beaune depuis les temps les plus reculés jusqu'à nos jours (Beaune: Imprimerie Ed. Batault-Morot, 1854), 364.
} 
individuals attempted to shield the city from such unwanted influence. ${ }^{4}$ As the century and the conflict continued, Beaune's efforts to protect itself and its inhabitants failed, as the Huguenots invaded and began governing the city in $1561 .^{5}$ Continual and violent conflict continued throughout the latter half of the sixteenth century with Catholic and Calvinist forces fighting over Beaune. Along with the constant presence of the Huguenots, Beaune also endured civil wars in 1567 and $1589 .^{6}$ Due to these conflicts and the state of perpetual attack and defence, the city experienced poverty and famine which compounded the state of uncertainty and fear. ${ }^{7}$ In Burgundy more generally, an increase in poverty which began in the 1530 's continued into the 1630 's and contributed to the overall sense of disorder and worry in many of the towns, including Beaune. ${ }^{8}$

With the end of the Wars of Religion Beaune entered into a more peaceful and perhaps more stable period. Huguenots were expelled from Beaune in 1598 which likely provided some degree of relief to the majority Catholic population. Although the Wars of Religion were officially over, conflict in Beaune persisted once more in 1621-1629 when the city fought against the nearby Huguenot population in Volnay. ${ }^{9}$ The feelings of animosity between Protestants and Catholics and the recent memories of the Wars of Religion were evidently still felt in the seventeenth century and would play a role in the introduction of new religious orders such as the Discalced Carmelites and the development of contemporary Catholic spirituality including the devotion to the infant Jesus.

\footnotetext{
${ }^{4}$ Ibid., 367, 371.

5 Ibid., 374-375.

${ }^{6}$ Ibid., 383, 392.

${ }^{7}$ Ibid., 368, 384.

8 James R. Farr, Authority and Sexuality in Early Modern Burgundy (1550-1730) (New York: Oxford University Press, 1995), 16-17.

${ }^{9}$ Ibid., 405.
} 
In a number of sources related to the establishment of the Discalced Carmelites in France we see a concern for heresy and the need to battle against it. Indeed, the confraternity of the family of the infant Jesus, a religious association for lay individuals and nuns, was created in part as a means of preserving the Catholic faith and battling against heresy. It is important to note, therefore, that the Wars of Religion and the relationship between Protestants and Catholics in the Burgundy region and Beaune in particular influenced the creation of new religious orders and the ways in which new devotions, such as that of the infant Jesus, manifested themselves. Indeed, a number of new religious orders entered Beaune at this time: Visitandines, Ursulines, Dominicans, Cistercians and of course, the Discalced Carmelites. ${ }^{10}$ These new monastic communities were in part a reaction to the Protestant attacks and the perceived threat to the Catholic community of Beaune. By means of these new religious orders Beaune sought to assert its Catholic identity. Perhaps the presence of these nuns offered a sense of stability and protection against the nearby Calvinists as they would surely be praying for the success of the Catholic population. Despite the local residents' initial hesitance of accepting them into Beaune, the Discalced Carmelites may have been seen as contributors to a sense of restoration and renewed order within Beaune.

Additionally, although the Edict of Nantes, which called for peaceful co-existence between Catholics and Protestants, was signed in 1598, the Burgundy region delayed its

\footnotetext{
${ }^{10}$ Roland-Gosselin, Le Carmel de Beaune, 29. Male religious houses in Beaune during the seventeenthcentury include the Cordeliers (f.1248), Carthusians (f.1332), Dominicans (f.1476), Capuchins (f.1606), Minimes (f.1625). Female religious houses in Beaune at this time were all founded after the Discalced Carmelite convent and include Ursulines (f.1626), Visitandines (f.1632), Dominicans (f.1632), Cistercians (f.1636). See Joseph Délissey, Le vieux Beaune, (Beaune: Imprimerie Mad. Girard, 1941) for more information regarding each of these foundations.
} 
publication and did not fully accept it until May $29,1600 .{ }^{11}$ In fact, many of the provincial parlements of France delayed their acceptance of the Edict of Nantes as much as possible. ${ }^{12}$ Although the edict allowed for "temporary religious co-existence" it was not a "systematic policy of toleration.", Indeed, the Edict of Nantes "hardly marked the end of fighting" amongst Protestants and Catholics. ${ }^{14}$ Many Catholics remained hesitant to peacefully co-exist with Huguenots for fear that they would still be able to regroup and advance their attacks. $^{15}$

This indicates the hesitance in Burgundy to extend religious toleration to Protestant denominations. Indeed, Beaune was quite in opposition to the settlement of Calvinist populations in the region. Throughout $1609-1610$, the Calvinists attempted to establish their own church and community in Beaune. This was met with opposition from the local Catholic population. Despite a petition signed by 297 opposing individuals King Henry IV permitted the establishment of the reformed church in nearby Volnay. ${ }^{16}$ Throughout the seventeenth century, the Calvinists struggled to establish their own community in the Volnay region and they made periodic efforts to enter into Beaune proper and settle there. Beaunois residents evidently remained concerned for the safety and security of their town and sought to maintain distance between themselves and the nearby Huguenots. Despite the Edict of Nantes, the local population and parlement of Beaune continued to oppose any real co-existence with Protestants.

\footnotetext{
${ }^{11}$ François Caudwell, "L'église réformée de Beaune au XVIIe siècle," Bulletin de la Société de l'Histoire du Protestantisme Français 138 (1992): 344.

${ }^{12}$ Mack P. Holt, The French Wars of Religion, 1562-1629 (Cambridge: Cambridge University Press, 1995), 168.

${ }^{13}$ Ibid., 163.

${ }^{14}$ Ibid., 3.

${ }^{15}$ Ibid., 168.

${ }^{16}$ Caudwell, "L'église réformée de Beaune," 347.
} 
Seventeenth-century Beaune was therefore greatly impacted by the Wars of Religion and the continuing animosity between Catholics and Calvinists of the region. The Discalced Carmelites entered Beaune and began to practice and spread their devotion to the infant Jesus in the socio-religious environment discussed above.

\section{Founding of the Beaune Convent}

"De temps immemorial, fut erigée au faubourg de la ville et chateau de Beaune, une eglise à l'honneur du glorieux S. Estienne premier martir."17 Thus begins a seventeenth-century account of the origins of the Beaune convent. This document outlines the history of the St. Etienne priory which became the residence of the Discalced Carmelites in 1619. After a brief history of this church, the account arrives at the conversion of this building into the Carmelite convent. Unsurprisingly, the foundation of the convent is described as the product of divine will and the result of much prayer. ${ }^{18}$ The foundation of this monastery was facilitated by Léonard Bataille, prior of St. Etienne and the uncle of Marguerite du Saint Sacrement. His agreement to allow the Discalced Carmelites to establish their convent within the old priory was the first step in the foundation of the monastery. ${ }^{19}$ The establishment of the convent is described as full of great trials and much work, but, with God's guidance and protection, the abbess of Dijon and all those whose help she employed succeeded in the foundation. ${ }^{20}$

\footnotetext{
${ }^{17}$ Beaune, AM, Archives du Carmel, 40, "Fondation du Monastère des Carmélites de Beaune," 11. "From time immemorial a church in honour of the glorious St. Etienne, first martyr, was erected on the outskirts of the town and castle of Beaune." This is believed to have been written by Elizabeth de la Trinité.

${ }^{18}$ Ibid., 15-16.

${ }^{19}$ Ibid., 17.

${ }^{20}$ Ibid., 16.
} 
This seventeenth-century interpretation of the founding of the Beaune convent provides us with an account of how the nuns understood and perceived the establishment of their convent. While most of this version of the founding corresponds with other sources on the subject, it fails to mention certain important details that we now know about the foundation of the Beaune convent, particularly with regards to the relationship between the nuns and the laity. As mentioned earlier, the Carmelites of Beaune and the local lay population were tied to one another through their mutual devotion to the infant Jesus. However, the relationship between the cloister and the town began well before Marguerite du Saint Sacrement and the institution of the new devotion.

On November 5, 1618, an assembly of Beaunois inhabitants met to discuss the possibility of the establishment of a Discalced Carmelite convent in their town. At this meeting, the local population expressed their hostility towards the new convent because of the already large number of religious houses in Beaune. ${ }^{21}$ Like many French towns of this period, Beaune wanted to limit the foundation of new monasteries and convents due to the financial burden they imposed. ${ }^{22}$ It seems as though the arrival of the Carmelite nuns "was the greatest misfortune in the world. Some said that they must not let them enter the town, others summoned them at the prior's door in order to oppose their establishment. ${ }^{23}$ Despite the hostility and apparent resistance of the local population to this foundation, the Discalced Carmelites were permitted to establish their convent, largely due to a letter from the king, Louis XIII, expressing his approval of the new

\footnotetext{
${ }^{21}$ Délissey, Le vieux Beaune, 295. Based on information cited above regarding the religious houses in Beaune during this period, all of the monasteries that existed in Beaune prior to the establishment of the Discalced Carmelites were male monastic orders.

${ }^{22}$ Roland-Gosselin, Le Carmel de Beaune, 29.

${ }^{23}$ Ibid., 29.
} 
religious house. ${ }^{24}$ Given the authority of the king, the mayor of Beaune could not do otherwise than permit the establishment. Thus, the seven nuns from Dijon officially entered their new home on July 25, 1619.

The initial resistance of the Beaune laity to the establishment of the Carmelite convent is interesting given their later amicable and intimate relationship with one another. Correspondance between lay individuals and the Carmelite nuns suggests a strong connection between the hidden cloister and the outside world. Throughout the seventeenth century, numerous letters were written to and from Discalced Carmelite nuns and the inhabitants of Beaune as well as other regions in France. ${ }^{25}$ Although the assembly of 1618 demonstrated the resistance of some inhabitants to the establishment of the new convent, others strongly supported the venture, such as the three sisters who began the process of bringing the Discalced Carmelites to Beaune. That the initial request for the convent began with Françoise, Catherine and Marie Richard, three sisters from a prominent family in Beaune, indicates the local initiative and character of the founding of the convent. ${ }^{26}$ From the very beginning it seems that the Beaune convent was closely related to lay initiative, if not dependant upon it. While the establishment of the convent would have been impossible without additional ecclesiastical support and approval, the involvement of the local population remained integral to the success of the convent.

This involvement of the laity may in part be explained by the seventeenth-century efforts throughout Burgundy to bring the "cloister to the street."27 Laity and clergy alike

${ }^{24}$ Délissey, Le vieux Beaune, 296.

${ }^{25}$ See Marguerite du Saint Sacrement: Correspondance (lettres reçues).

${ }^{26}$ Roland-Gosselin, Le Carmel de Beaune, 27.

${ }^{27}$ Farr, Authority and Sexuality, 33. 
sought the "sacralization of society," integrating the sacred into family life and politics. This period witnessed great efforts to restore community and impose a new moral order after the chaos and destruction of the Wars of Religion. ${ }^{28}$ Such emphasis on renewing society and finding new places and spaces for religious belief and practice may have contributed to the close, interdependent relationship between the Beaunois laity and the Carmelite convent.

It is striking therefore, that despite the initial fervour for the convent amongst some individuals, others were evidently quite opposed. Scholars attribute this largely to the fact that Beaune was already home to a large number of religious houses and the local population believed it would be financially detrimental to allow new foundations. There is likely more involved in the local population's early resistance to the new convent, such as issues of class, personal interest, etc. Conflict between Catholics and Protestants continued to persist and the social and economic stability of Beaune remained weak. Moreover, the population of Burgundy during this time is said to have had a "compulsion for order."29 Perhaps local inhabitants were wary of even more change imposed upon their town. Indeed, the introduction of yet another religious order into Beaune may have been seen as a threat to the renewal of order. Despite the complex and at times contradictory nature of the relationship between the order and the local laity, the Discalced Carmelite convent thrived and spiritual ties between nuns and lay dévots strengthened throughout the seventeenth century.

We return now to Elisabeth de la Trinité's account of the establishment of the Beaune convent. A few days after their arrival in Beaune and the beginning of their

\footnotetext{
${ }^{28}$ Ibid., 8.
}

${ }^{29}$ Ibid., 18. 
establishment, the Discalced Carmelites received a visitor who was to be integral in the distinct spirituality of their order. Léonard Bataille presented his niece, Marguerite du Saint Sacrement, at the time only six months of age, to the nuns who promised to accept her as their founder as soon as she was ten or twelve years old. ${ }^{30}$ Eleven years later, after the death of her mother, Marguerite entered the Carmelite convent on September 24, 1630 and thus began her life as a Discalced Carmelite nun. ${ }^{31}$

This part of the foundation story of the Beaune convent is important as it sets the stage for what was to come in terms of Marguerite du Saint Sacrement's role in the convent's devotion to the infant Jesus. The emphasis on Marguerite's entrance demonstrates the importance of her role within the convent. The account relates that despite her young age, Marguerite exemplified virtue and perfection. ${ }^{32}$ It is no wonder therefore that 'S. Estienne avait demandé à nostre Seigneur Jesus-Christ qu'il donnast son Eglise et sa maison aux filles de la Ste. Vierge, puis que la Sainte Vierge destinait cette sainte petite Enfant pour estre de ses filles et que $\mathrm{S}$. Estienne devait estre maistre et conducteur de cette [bienheureuse] petite ame." ${ }^{33}$ Elisabeth de la Trinité believed that the founding of the Discalced Carmelite convent in Beaune was in accordance with divine will and that Marguerite du Saint Sacrement's acceptance into the order was of particular significance since she was chosen by St. Etienne, the Virgin Mary and God himself to guide the convent with the development of a new devotion to the infant Jesus.

\footnotetext{
${ }^{30}$ Archives du Carmel, 40, 18, Roland-Gosselin, Le Carmel de Beaune, 33, and Délissey, Le vieux Beaune, 296.

${ }^{31}$ Archives du Carmel, 40, 18; Marguerite du Saint Sacrement: Correspondance, lettres écrites, 15.

${ }^{32}$ Archives du Carmel, 40, 18-19.

${ }^{33}$ Ibid., 18. "St. Etienne asked Our Lord Jesus Christ that he give his church and his house to the daughters of the Blessed Virgin, since the Blessed Virgin destined this holy little child to be her daughter and that St. Etienne must be the master and conductor of this blessed little soul."
} 
This local historical context situates the Carmelites of Beaune within their temporal and physical environment and contributes to a more complete understanding of the spirituality that developed within the convent walls. From here we can turn to a discussion of the religious and spiritual context of seventeenth-century Beaune which was deeply linked with the devotion to the infant Jesus.

\section{The Infant Jesus, l'École Française and the Spirituality of Beaune}

Beaune's spiritual and theological environment is of utmost importance for this thesis. As this thesis deals primarily with the devotional lives of the Discalced Carmelite nuns, it is important to understand the religious context within which the spirituality of the Beaune convent developed. Like other religious developments of the period, the devotion to the infant Jesus as understood and practiced within the Beaune convent had its own origins and influences. In this section I will discuss the earlier roots of the devotion to the infant Jesus, its origins in Christian tradition throughout the medieval period as well as within the history of the Discalced Carmelite order itself. I will also explore a more specific, more local and particularly French influence upon the spirituality that developed within the Carmelite convent in Beaune. Historians refer to this particular development in seventeenth-century French Catholic piety as the école française. This new spirituality had a significant impact on the nature of the devotion to the infant Jesus among the Carmelites. It is my intention here to analyze the primary tenets of the école française and the nature of its relationship with the Beaune convent. In so doing, I will establish the foundation for understanding the specific ways in which the Discalced Carmelites practiced their devotion to the infant Jesus. 


\section{A Brief History of the Origins of the Devotion to the Infant Jesus}

The essential characteristics of the devotion to the infant Jesus were developed in Spain, the direct source for the seventeenth-century French devotion. ${ }^{34}$ The devotion to the infant Jesus was central to the spirituality of Teresa of Avila's Carmelites. Its origins, however, date prior to the sixteenth century. Early Christians focused on Christ's infancy to some extent by making pilgrimages to places where he was believed to have visited or lived. Within the early churches we find the first frescoes depicting scenes from the life of Christ, including the visit of the three Magi. ${ }^{35}$ The Church Fathers spoke of the infant Jesus, particularly with regards to his divinity, defending the belief that Christ was human yet divine. ${ }^{36}$ The emphasis at this time was largely theological rather than spiritual, emphasizing and clarifying the importance of Christ's divinity. ${ }^{37}$ In addition to the writings of the Church Fathers, evidence of interest in the infancy and childhood of Christ during the years of the early Church is found in liturgical celebrations, literature and pilgrimages to Bethlehem. ${ }^{38}$

In the eleventh and twelfth centuries Bernard of Clairvaux and the Cistercians celebrated key events in the life of Christ, such as his birth and circumcision. The liturgical celebration of these events provided the occasion to celebrate the infant Jesus. ${ }^{39}$ The advent of the Franciscans in the thirteenth century introduced new elements into the devotion to the infant Jesus. Indeed it is at this time that Francis of Assisi "set up for the first time a Christmas crèche scene, so that the faithful might more easily envision the

\footnotetext{
34 "Enfance de Jésus (dévotion à l')," in Dictionnaire de spiritualité ascétique et mystique: doctrine et histoire, eds. Marcel Viller et al., vol.4 (Paris: Beauchesne, 1960), 664.

${ }^{35}$ Sr. Jehanne d'Arc, "Le bonheur de l'autre monde," 1, recorded November 29-30 2008 at the Centre Spirituel des Sables d'Olonne "Relais Pascal," available at http://www.exultet.net.

36 "Enfance de Jésus (dévotion à l')," Dictionnaire de spiritualité, 653.

${ }^{37}$ Ibid., 654.

${ }^{38} \mathrm{Ibid} ., 656$.

${ }^{39}$ Ibid., 658.
} 
tenderness and humility of the new-born Jesus. ${ }^{, 40}$ Additionally, the infant Jesus appeared to a number of Franciscan men of the period, such as Francis of Assisi and Anthony of Padua, both of whom had physical contact with the child Jesus through embracing him. Mary Dzon writes that these "mystical experiences...gave the Christ Child's devotees an opportunity to express their love for him in a tangible way. ${ }^{, 41}$

Of more significance still are the interactions between women and the child Jesus. Caroline Walker Bynum has explored the bodily experiences of women with regards to their interactions with the infant Jesus. She writes that the somatic experiences of medieval women were at times a continuation of their social roles: "not only did female mystics kiss, bathe and suckle babies in visions...they actually acted out maternal and nuptial roles in the liturgy, decorating life-sized statues of the Christchild for the Christmas crèche or dressing in bridal garb when going to receive their bridegroom in the Eucharist. ${ }^{, 42}$ In Chapter Two, I will explore the motherhood behaviour of the Discalced Carmelites towards the infant Jesus, as well as the physical and mental ways in which the nuns adored the infant Jesus through such tangible expressions.

An important aspect of the medieval devotion to the infant Jesus was the use of statues. This practice began with the Franciscans and grew out of the introduction of the crèche. Although it began as a living nativity scene, smaller crèches were made using statues and small figurines. ${ }^{43}$ Examples of the use of such statuettes include fourteenthcentury Dominican nun Margaret Ebner's little figure of the infant Jesus and Margery

\footnotetext{
${ }^{40}$ David Herlihy, Women, Family and Society in Medieval Europe, Historical Essays 1978-1991 (Providence: Berghahn Books, 1995), 240.

${ }^{41}$ Dzon, "The Image of the Wanton Christ-Child," 60.

${ }^{42}$ Caroline Walker Bynum, Fragmentation and Redemption: Essays on Gender and the Human Body in Medieval Religion (New York: Zone Books, 1991), 198.

${ }^{43}$ Sr. Jehanne d'Arc, "Le bonheur de l'autre monde,"l.
} 
Kempe's fifteenth-century accounts of witnessing women in Rome paying motherly attention to a small statue of the Christ Child. ${ }^{44}$

The use of such statues in the practice of the devotion to the infant Jesus continued and thrived within the Carmelite convents of Teresa of Avila's reform. ${ }^{45}$ Indeed, the role of statues in sixteenth-century Spanish devotion in general assumed a new form. Rather than making simple statues out of wood, many were now adorned with brocade, a fabric woven with elaborate designs. In addition, devotees decorated these statues with silk and precious stones. ${ }^{46}$ This new attitude towards statues and their decoration penetrated Teresa's convents in the form of little statues of the infant Jesus, richly adorned and present in almost all of the Discalced Carmelite convents. Indeed, Teresa of Avila carried a statue of the infant Jesus with her when she travelled since it helped her to constantly elevate her soul towards God, just as if she was within her own convent. $^{47}$

The image or statue of the infant Jesus was a crucial component of the devotion to the infant Jesus in the Spanish Discalced Carmelite convents. In part it demonstrates how this piety was practiced, but it also indicates the importance of Christ's humanity. Teresa of Avila's mysticism was characterized by a focus on Christ's humanity, within which his divinity was believed to be hidden. ${ }^{48}$ Thus, the Incarnation assumed a new importance along with the celebration of the birth of Christ and adoration of the Eucharist, both christocentric devotions. ${ }^{49}$

\footnotetext{
${ }^{44}$ Dzon, "The Image of the Wanton Christ-Child," 61.

45 "Enfance de Jesus (dévotion a l')," Dictionnaire de spiritualité, 664.

${ }^{46}$ Giovanna della Croce, o.c.d., L'enfant Jésus au Carmel: histoire et spiritualité, trans. Raymond Lamarque (Toulouse: Éditions du Carmel (Collection Carmel Vivant), 2005), 22.

${ }^{47}$ Ibid., 24.

${ }^{48}$ Ibid.

${ }^{49}$ Ibid., 50.
} 
With their arrival in France, the six Spanish nuns brought with them their intense devotion to the infant Jesus. The introduction of the Discalced Carmelites in France was a complex and delicate affair, one that has been analyzed in some detail. ${ }^{50}$ Of significance is the role of the devotion to the infant Jesus in the debate and decision surrounding the introduction of the order to France. François de l'Enfant Jésus, one of the individuals involved in bringing the Discalced Carmelites to France, wrote the following to Mère Anne de Jésus:

À ma soeur très chère et tres aimée...Anne de Jésus que l'Enfant Jésus a choisie pour faire du bien aux âmes de France...N'oubliez pas de chercher à être en France ce que notre sainte Mère a été pour l'Espagne! Par conséquent, ma Soeur, mettez-vous à l'oeuvre avec un grand courage pour l'Enfant Jésus et sa sainte Mère Marie, et à l'imitation de notre sainte Mère...Ne manquer de consulter Dieu: c'est le moyen de réussir; demandez-lui de vous soutenir de sa main, et de vous embrasser de l'amour de l'Enfant Jésus!...Ayez confiance en lui. ${ }^{51}$

This letter indicates the importance of the infant Jesus in the decision to introduce the Discalced Carmelites to France. Here, François de l'Enfant Jésus appeals to Anne de Jésus's desire to be faithful to Teresa of Avila's work as well as her personal devotion to the infant Jesus. By drawing upon the belief that the infant Jesus himself desired the order to be brought to France, this letter attempts to persuade Anne de Jésus that her role in France was similar to that of Teresa of Avila in Spain. From the beginning of the

\footnotetext{
${ }^{50}$ See Hours, ed., Carmes et Carmélites en France and Morgain, Pierre de Bérulle et les Carmélites de France.

${ }^{51}$ Della Croce, L'enfant Jésus au Carmel, 56-57. "To my beloved and most loved sister...Anne de Jésus that the infant Jesus chose to do good among the souls of France... Do not forget to try to be in France what our blessed Mother was for Spain! Consequently, my sister, implement this with great courage for the infant Jesus and his blessed Mother Mary and in imitation of our blessed Mother...Be sure to consult God: it is the means of succeeding; ask him to support you with his hand, and to embrace you with the love of the infant Jesus!...Have confidence in him."
} 
discussions and negotiations regarding the introduction of the Discalced Carmelites in France, the devotion to the infant Jesus was at the heart of the matter.

After the successful installation of the Spanish Discalced Carmelite nuns in Paris, additional religious houses of the order spread throughout France. One of the earlier foundations was that of Dijon, and it was nuns from this religious house that later founded the convent in Beaune in 1619. Anne de Jésus, the same nun to whom François de l'Enfant Jésus pleaded to come to France, was integral in the founding of both convents. ${ }^{52}$ To these convents, Anne de Jésus brought statues of the infant Jesus, in imitation of Teresa of Avila's actions when founding her Spanish convents. Indeed, Anne de Jésus brought four statues of the infant Jesus with her from Spain, three of which were placed in various locations in the Dijon convent. The fourth and last statue found its home in the convent in Beaune. ${ }^{53}$ The use of these statues symbolizes "the spirit of simplicity, poverty, and obedience, this attachment to the humanity of Christ." ${ }^{\text {, }}$ As I will explore in Chapter Three, simplicity, poverty and obedience are precisely the characteristics and attitudes that the Carmelites of Beaune are encouraged to develop in imitation of the infant Jesus.

Moreover, the use of little figures of the Christ Child in the devotion to the infant Jesus is an important aspect of the devotional practices of the nuns at Beaune as well. Correspondance to and from the Beaune convent indicates that statues of the infant Jesus were present and circulated amongst the convents in France and among the laity. In addition, the Carmelites of Beaune were known for their skill in making small wax statues of the infant Jesus, evidence that the intense devotion to the infant Jesus that

${ }_{53}^{52}$ Roland-Gosselin, Le Carmel de Beaune, 2.

${ }^{53}$ Ibid., 6.

${ }^{54}$ Ibid., 5. 
characterized the Spanish carmels was deeply integrated into the Beaunois spirituality as well. ${ }^{55}$

Thus from the very beginning of the founding of the Discalced Carmelite convents in France, the Spanish devotion to the infant Jesus, fashioned by Teresa of Avila and her nuns, formed an integral component of the order. It is clear that the devotion to the infant Jesus that developed and thrived within the Beaune convent was in part influenced by the spirituality of the Dijon convent. Similarly, the devotional focus on the infant Jesus at Dijon had its own influences, most notably the Spanish founders, but also the theological and devotional currents particular to France. In this respect, the Dijon and Beaune convents share a common influence: Pierre de Bérulle and the école française. The following will explore the école française and its relationship with the Beaune convent and its devotion to the infant Jesus.

\section{L'école Française and the Spirituality of the Beaune Convent}

In his monumental work on the history of religious sentiment in France, Henri Brémond writes the following of the école française: "this school [is] indisputably the most original, the richest and the most fruitful" of the seventeenth century. ${ }^{56}$ The école française was "[a] school, but of the interior life, of high spirituality, and not of theology. ${ }^{, 57}$ This distinction is important. The spirituality of the école française, although approved by the universal Church, did not seek to formulate a theology, nor did it attempt to change or create new official Catholic dogma. Pierre de Bérulle, the pivotal

\footnotetext{
${ }_{55}^{55}$ Marguerite du Saint Sacrement: Correspondance (lettres reçues), 280, 306, 382.

${ }^{56}$ Henri Brémond, Histoire littéraire du sentiment religieux en France: depuis la fin des guerres de religion jusqu'à nos jours, vol.3.1 (Paris: Librairie Armand Colin, 1967), 9.

${ }^{57} \mathrm{Ibid}$., 10.
} 
figure of this school, and his disciples sought a particular type of spirituality or piety which placed Christ at the centre. Certain key aspects of this new form of piety illuminated the devotion to the infant Jesus within the Carmelite convent in Beaune. This section will explore the main tenets of the école française as they relate to the devotion to the infant Jesus which developed amongst the Carmelites of Beaune. I will discuss two essential characteristics of the école française: adherence to the Word Incarnate and annihilation of the self. ${ }^{58}$

The Incarnation and the humanity of Christ formed the foundation of the école française. Giovanna della Croce writes that:

Bérulle opened the way to a life centered on Christ and based on this principle: man is nothing, but this nothing is able to welcome God and elevate itself to Him through prayer. The recognition of our own nothingness in face of the absolute God leads to an attitude of profound respect and adoration...At the center is Christ who by his Incarnation redeemed and sanctified man. It is through Christ that man adores God, and it is in the mystery of his Incarnation that man finds the solution allowing him to reduce the distance separating him from God. ${ }^{59}$

This excerpt reveals two of the central tenets of the école française: the humanity of Christ and the abandonment of oneself in submission to the will of God. As we have seen, this focus on Christ's humanity is not particular to seventeenth-century France; however through Bérulle and the école française, the ways in which devotees thought of and embodied this spirituality certainly changed. Bérulle advised that Christ should be adored as a man, united to the human condition. But he looked to him not only as God, nor as merely a man, but as both. In doing so, Bérulle emphasized Christ's greatness and

\footnotetext{
${ }^{58}$ Ibid., 204.

${ }^{59}$ Della Croce, L'enfant Jésus au Carmel, 125-126.
} 
his lowliness, his divine and human filiations. ${ }^{60}$ This indicates the spiritual attitude of Bérulle and the fundamental principles from which the entire spirituality developed. ${ }^{61}$ For Bérulle, the humanity and divinity of Christ were inseparable. He was believed to be both God and man at all times and should therefore be adored as such. The emphasis was therefore on the unity of Christ's two natures, which were joined together "by a link so dear, so narrow and so intimate...the divinely human and humanly divine life of the ManGod." 62 Christ's dual nature of divine yet human formed the crux of the école française. Bérulle wrote the following in a reflection on Christ's infancy: "Puisque Dieu cherche la terre, aime la terre, je veux me tourner maintenant, non vers le Ciel, mais vers la terre, et y chercher Jesus-Christ. ${ }^{, 63}$ He explained that God was not only present in Heaven, but chose to come down to earth and assume the weak and humble form of an infant. In this way, God assumed "un estat d'abaissement, d'assujetissement et d'impuissance." ${ }^{64}$ Since God took on human form and lowered himself to a position without power and without might, those who strived to adore and follow Christ had to seek him not in Heaven, but on earth, as Bérulle suggested. And if one was to search for God on earth, one had to begin with the very beginning and follow him throughout all of the stages of his life. In this way, the Discalced Carmelites sought to adore God Incarnate in every aspect of his earthly life, from his conception in Mary's womb to his death on the cross.

${ }^{60}$ Brémond, Histoire littéraire, vol.3.1, 50.

${ }^{61}$ Ibid.

${ }^{62}$ Ibid., 52.

${ }^{63}$ Le petit office du saint enfant Jésus (Paris: François Muguet, 1697), 186. "Since God seeks the earth, loves the earth, I want to turn myself now, not towards Heaven, but towards the earth, and here seek Jesus Christ."

${ }^{64}$ Ibid. "a state of lowering, subjection and helplessness." 
The christocentrism of Bérulle's spirituality and that of the école française influenced the Discalced Carmelites of France. ${ }^{65}$ As mentioned above, the Dijon convent was very much influenced by the spirituality of Teresa of Avila and her devotion to the humanity of Christ, but it was also greatly marked by the spirituality of Bérulle. ${ }^{66}$ One nun in particular demonstrates these links. Marie de la Trinité professed her vows at the Discalced Carmelite convent of Dijon in 1617. After moving to Beaune, she was maitresse des novices between 1625 and 1635 and acted as prior between 1635 and 1641 . She also played a very important role in the spiritual formation of Marguerite du Saint Sacrement, who was influential in the development of the devotion to the infant Jesus and whose spirituality borrowed much from the école française.$^{67}$ In this way, Marie de la Trinité is a good example of the connections between Teresa of Avila, Pierre de Bérulle, and the Dijon and Beaune convents, particularly in terms of spiritual and devotional threads.

Along with the emphasis on the humanity of Christ came the focus on the Incarnation and the nativity of Christ in particular. Here we see more concretely the connections between the école française and the devotion to the infant Jesus. Though the devotion to the infant Jesus was an old tradition, Bérulle transformed it and made it his own. During the first half of the seventeenth century the devotion to the infant Jesus grew in success and spread throughout France.$^{68}$ However, the more popular the devotion to the infant Jesus became the more the spirituality moved away from the

\footnotetext{
${ }^{65}$ See Morgain, Pierre de Bérulle et les Carmelites de France, for a thorough history of the relationship between Bérulle and the Discalced Carmelites of France, not only in terms of spirituality, but mostly in terms of the organization, supervision and politics of these new convents.

${ }^{66}$ Roland-Gosselin, Le Carmel de Beaune, 39.

${ }^{67}$ Ibid., 35-36.

${ }^{68}$ Brémond, Histoire littéraire, vol.3.2, 204.
} 
direction of the école française. ${ }^{69}$ The Beaune convent, as we shall see, was an interesting example of this. Largely responsible for the popularity of the devotion to the infant Jesus, the nuns of the Beaune convent were undoubtedly inspired and influenced by the spirituality of the école française but they also internalized the devotion and made it particularly Carmelite. Interestingly, other devotions also became "bérulliennes" such as the devotion to the Blessed Sacrament, the Virgin Mary and Saint Joseph, all important aspects of the spirituality of the Discalced Carmelites of Beaune. ${ }^{70}$ As Chapters Two and Three will demonstrate, these devotions were intricately connected with that of the infant Jesus and allowed the nuns to adore, venerate and imitate the infant Jesus in specific ways. That these devotions were also influenced by the école française further strengthens the ties between the Beaune convent and its spiritual milieu, offering a context within which we can analyze the spirituality and devotional practices that developed there.

Loyal to the christocentric emphasis of the école française, Bérulle wrote the following regarding the devotion to the infant Jesus: "Or le premier état auquel nous trouvons le Fils de Dieu au monde, c'est son enfance: le premier état aussi auquel nous le devons contempler et révérer, c'est celui-là.,"11 Before all other considerations, prayers or acts of adoration, Christians needed to contemplate Christ in his infancy. Indeed, "la dure réalité, cachée sous 'la grâce et la bénignité' qui nous sont apparues avec cet enfant, c'est l'anéantissement du Verbe Incarne.,"72 In Bérulle's own words the annihilation of the

\footnotetext{
${ }^{69} \mathrm{Ibid}$.

${ }^{70} \mathrm{Ibid}$.

${ }^{71}$ Oeuvres complètes de Bérulle disposées dans un ordre logique (Paris: Migne, 1856), 1008. "And yet the first state in which we find the Son of God in the world, is his infancy: this is also the first state of which we must contemplate and revere him."

${ }^{72}$ Ibid., 1395. "The hard reality, hidden beneath 'the grace and mildness' that appeared to us with this infant, is the annihilation of the Word Incarnate."
} 
Word Incarnate is a "mystère de naissance et de vie; mystère de vie souffrante et mourante, car, en icelui Jésus prend vie pour mourir."73 ${ }^{, 7}$ Perhaps we see here what we will later see amongst the nuns at Beaune, that is, the inseparability, of the infancy and the Passion, since Bérulle emphasized that Christ took on the life of an infant precisely in order to suffer and die.

In order to understand Bérulle's interpretation and contemplation of the infant Jesus, "it is necessary to first dispel affectionate, happy images that evoke the memory of the first Christmas... The very particular devotion to which Bérulle invites us has nothing that touches the senses or that moves the heart. Naked, severe, unforgiving, it speaks only of humiliation and death."74 Interestingly, despite their strong connection to the école française and the particular spirituality of Bérulle, the Carmelites of Beaune distanced themselves from this aspect of the devotion to the infant Jesus. Though they certainly linked the infancy, suffering and death of Christ, they did not focus solely on humiliation and death as Bérulle does. The devotion to the infant Jesus at Beaune involved affection, caring and a maternal attitude. Already we can see the ways in which the Carmelites of Beaune included certain aspects of Bérulle's spirituality and omitted or adapted others.

"L'anéantissement" of Christ in his infancy was perhaps the most crucial aspect of the spirituality of the école française. This term translates poorly into English, but its meaning is akin to annihilation or destruction. It also seems to suggest a humbling, or entering a lower state of existence. Bérulle's language when he talked about the infancy as the annihilation or destruction of Christ is interesting, if not surprising. Is not the state

\footnotetext{
${ }^{73} \mathrm{Ibid}$. "mystery of birth and of life; mystery of life suffering and dying, for, Jesus takes life to die."

${ }^{74}$ Brémond, Histoire littéraire, vol.3.2, 205.
} 
of an infant, as the very first part of life, far from annihilation and destruction? Why does Bérulle talk about the birth of the infant Jesus as the destruction of Christ? His understanding or interpretation of infancy and childhood helps to explain his language and approach to the devotion to the infant Jesus. The following summation of Bérulle's perception of infancy and childhood provides us with an explanation:

The state of infancy is it not 'in nature the most opposite of intelligence'? Is it not the 'the most vile and most despicable state of human nature, after that of death'? It is for this [reason] that the divine Word chose it, unable to find anything more 'humble', nor 'despicable', lowering himself to this point, 'in the particular state of this mystery, that no other kind of lowering seemed equal to it'...And without doubt, the infant Jesus assumed only on the outside these inabilities common to all other children. It is for this that we adore him. ${ }^{75}$

An infant, according to Bérulle was the lowest, humblest most abject human state. Christ chose to assume this state precisely for this reason. But although he took on the lowest state possible, that of a child, he did so only on the exterior, without adopting the "incapacities" of other children. As will be discussed in Chapter Three, certain childlike qualities such as innocence and obedience are associated with the infant Jesus, and those who seek to follow and imitate him are encouraged to mimic his childlike attributes.

In an article regarding the devotion to the Holy Family in the spirituality of the école française, John Saward refers to the Incarnation as the "self-abasement" of Christ. ${ }^{76}$ He goes on to say that "without change in His divine nature, without diminution of His infinite divine richness, the Son of God unites to Himself hypostatically, in the womb of

\footnotetext{
${ }^{75}$ Ibid., 206-207.

${ }^{76}$ John Saward, "The Earthly Home of the Eternal Father': The Holy Family in the Spirituality of the French School," in The Holy Family in Art and Devotion, ed. Joseph F. Chorpenning (Philadelphia: St. Joseph's University Press, 1998), 57.
} 
the Virgin, our poverty, a created human nature, a nature which, like everything created, is out of nothing. He makes Himself nothing, then, in this sense: by assuming our nothingness, our lowliness." ${ }^{, 77}$ By assuming human nature, Christ lowered himself to a state of poverty and nothingness. Bérulle elaborated, stating that one of the ways that the self-abasement of Christ was present in the Incarnation "[was] by [Christ] taking our human nature through the mystery of the Incarnation, thereby lowering the infinite and supreme being of [Christ's] divinity to the nothingness of our nature." 78 Not only did Christ assume the form of man, but he lowered himself even further by entering the world as a helpless infant. Saward writes that "had He wished, the divine Word could have formed a human nature for Himself in adult form...but he chose not to. He wanted to begin the human journey, as we do, in the lowliness of the womb. The Son of God freely and lovingly decided to be "mothered" into human nature, to be conceived and born of the Virgin Mary." 79 That Christ chose to assume human form as a child, considered the lowest and humblest of human states, became central to the spirituality of the école française and consequently, the Beaune convent.

Despite his perhaps negative view of infancy and childhood, Bérulle sought the development of an "esprit d'enfance" as opposed to a devotion. ${ }^{80}$ Bérulle and his followers were less inclined to create a particular devotion to the infant Jesus, rather they were interested in spreading "a particular 'spirit,' 'the spirit of Christian childhood., ,,81 This esprit d'enfance is not necessarily a devotion strictly speaking. Devotion can be defined in this case as "a collection of pious practices destined to honour the infancy of

\footnotetext{
${ }^{77} \mathrm{Ibid}$.

${ }^{78}$ Ibid.

${ }^{79} \mathrm{Ibid}$.

${ }^{80}$ Brémond, Histoire littéraire, vol.3.2, 211.

${ }^{81} \mathrm{Ibid}$.
} 
Jesus. ${ }^{182}$ This is where the Beaune convent took on such an important role, as it introduced particular devotional activities associated with the infant Jesus. The devotion to the infant Jesus therefore began with "a 'spirit,' a 'state,' a collection of 'interior' dispositions; and then 'exterior;' formulas, pious images, rules, confraternities" which developed in and around the Discalced Carmelites of Beaune. ${ }^{83}$ This is where the spirituality of the école française was limited, and where the developments in practical application in the Beaune convent began.

As we have seen, the esprit d'enfance of the école française revolved around "l'anéantissement" of Christ. In this way, the spirituality of Bérulle, and consequently the Beaune convent, involved an attitude of humble submission and abandon. Indeed, the esprit d'enfance of Bérulle was above all a spirit of anéantissement. ${ }^{84}$ Followers of Bérulle, especially those who interacted with the Beaune convent, were faithful to the spirituality of the école française, but the understanding of Christ's assumption of the form of an infant began to change. Brémond writes that "it is no longer death, nor selfsacrifice, it is 'abandonment,' and of a child in the arms of its mother" that was emphasized. ${ }^{85}$ Simplicity and innocence began to be associated with infancy, and the divine infancy in particular. The Discalced Carmelite convent in Beaune was important in these changes, especially in terms of the ways in which devotees practiced their spirituality. It is important to remember that "a spirit is not a devotion, in the narrow and popular sense of the word. The école française oriented the fervour of an elite towards

\footnotetext{
${ }^{82}$ Ibid.

${ }^{83}$ Ibid., 212.

${ }^{84}$ Ibid.

${ }^{85}$ Ibid., 214.
} 
the state of the newborn Word and of the Word as a child." 86 Bérulle and the école française offered a way of understanding the Incarnation and the infancy of Christ by fostering an esprit d'enfance. With Marguerite du Saint Sacrement and the Carmelites of Beaune, devotion to the infant Jesus grew in popularity and devotees gained a set of devotional behaviours, mental and physical, with which to adore the infant Jesus.

On the subject of Marguerite du Saint Sacrement's devotion to the infant Jesus, Marie-Françoise Grivot writes that Marguerite demonstrated a need to make concrete "in a colourful and daily way, a devotion that others (Bérulle and his school) practiced in a more abstract style." ${ }^{87}$ Bérulle's esprit d'enfance continued with Marguerite but in a less abstract and more concrete way, through the celebration of certain feasts, commemoration of all stages of Christ's infancy, Nativity plays and processions, and the use of statues of the infant. ${ }^{88}$ Bérulle's writings circulated in the Beaune convent and were read by many of the nuns. Marguerite therefore would be aware of the école française and its understanding of the divine infancy and its primacy in one's spiritual life. Grivot attests that Marguerite was inspired by Bérulle's writings and his spirituality, but she did not copy them. ${ }^{89}$ As we explore the various ways in which the Discalced Carmelites of Beaune practiced their devotion to the infant Jesus, the relationship between the école française and the Beaune convent will become clearer as will the distinct nature of the devotion among these nuns.

\footnotetext{
${ }^{86}$ Ibid., 217.

${ }^{87}$ Marguerite du Saint Sacrement: Correspondance (lettres reçues), 34.

${ }^{88}$ Subsequent chapters will explore such devotional behaviour in greater detail. I mention a few examples here to offer an idea of the ways in which the devotion to the infant Jesus was practiced and internalized as an "esprit d'enfance".

${ }^{89}$ Marguerite du Saint Sacrement: Correspondance (lettres reçues), 35.
} 
As was mentioned earlier, the devotion to the infant Jesus among the Discalced Carmelites did not begin with Marguerite under the influence of the école française, but was part of the order's spirituality since the beginning of Teresa of Avila's reform.

Likewise, the devotion to the infant Jesus as practiced by Marguerite du Saint Sacrement also had precedents among French Discalced Carmelites. Catherine de Jésus, a Carmelite from the Paris convent was also known for her fervent devotion to the infant Jesus. After her death in 1627 , an account of her life was distributed and read throughout the Discalced Carmelite convents in France. Brémond states that "during Marguerite [du Saint Sacrement]'s noviciate and her first years of the religious life, the carmels of Bérulle's observance read, reread and knew by heart the life [of Catherine de Jésus]." ${ }^{90}$ It is therefore likely that the life of Catherine de Jésus influenced Marguerite du Saint Sacrement and her devotion to the infant Jesus. Correspondence between the convents indicates that information, stories, and lives of certain nuns (particularly those considered especially devout) circulated amongst the convents in France. What is important about the reading of Catherine's life is the way in which it resembles and yet differs from the devotion popularized by Marguerite. Brémond suggests that "from the devotion rigorously and exclusively Bérulle's, of which Catherine remains a complete model, Marguerite will make a popular devotion, less sublime, les interior, less demanding, but

\footnotetext{
${ }^{90}$ Brémond, Histoire littéraire, vol.3.2, 223. For the life of Catherine de Jésus see La vie de soeur Catherine de Jésus, religieuse de l'ordre de Nostre Dame du Mont Carmel (Paris: Fiacre Dehors, 1628) and Pierre de Bérulle, La vie de Soeur Catherine de Jésus, religieuse de l'Ordre de Nostre-Dame du MontCarmel, estably en France, selon la réformation de Saincte Térèse de Jésus, décédée au convent du mesme Ordre, dit de la Mère de Dieu, en la ville de Paris, le 19 février 1620 (1623). Avec un recueil de ses lettres et pieux escrits (Paris: Fiacre Dehors, 1631). Note here the language of "carmels of Bérulle's observance" ("Carmels de l'observance bérullienne"), reinforcing the link between Bérulle and the Discalced Carmelite convents in France. For a detailed discussion of his relationship with the convents see Morgain, Pierre de Bérulle et les Carmélites de France.
} 
more accessible, more immediately practical and more humanly tender."91 The ways in which Marguerite developed this kind of popular and practical devotion and its presence within the Beaune convent forms the subject of this thesis. The following chapters will explore the nature of the devotion to the infant Jesus in terms of maternal behaviour through the imitation of Mary and the ways in which the nuns of Beaune fostered an esprit d'enfance through the imitation of Christ.

${ }^{91}$ Brémond, Histoire littéraire, vol.3.2, 225. 


\section{Chapter Two}

\section{Imitation of Mary}

“Je vous aime, je vous remercie, je vous loue et vous adore en cet esprit avec lequel votre chère Mère vous baisait avec tant de révérence. Ah que je puis-je l'imiter!"1 Dom Jacques de Sainte Marie, a Carthusian monk of Dijon, addressed himself to the infant Jesus in a letter to Marguerite du Saint Sacrement. He shared Marguerite's fervent devotion to Christ's infancy and expressed his adoration for Mary. In addition to revealing his desire to join Marguerite in her prayers to the infant Jesus and the journey of becoming a child like him, Dom Jacques offered advice on how to approach the infant Jesus in prayer. This prayer expresses an attitude of love, gratitude, worship and adoration of the infant Jesus, in imitation of Mary. As the excerpt above demonstrates, Dom Jacques wished to adore the infant Jesus in the same manner that Mary adored him. As will be discussed throughout this chapter, such desires to imitate Mary were common among the Discalced Carmelites of Beaune. Through the writings of priests, lay people and the nuns themselves we can see how the Carmelites imitated the Virgin Mary by acting as mothers of the infant Jesus.

Though strictly cloistered and bound to vows of virginity, and therefore never able to become biological mothers, the Discalced Carmelite nuns of Beaune were encouraged to behave in maternal ways. Specifically, they were encouraged to view Mary as a model of ideal motherhood. In this way, Mary was an example, indeed the perfect example, of how one should feel and act towards the infant Jesus. In this vein, Rosemary Hale writes that "Mary was a primary exemplar for nuns. She represented a

\footnotetext{
${ }^{1}$ Marguerite du Saint Sacrement: Correspondance (lettres reçues), 183. "I love you, I thank you, I praise you and adore you, in the spirit with which your dear mother kissed you with so much reverence. Oh that I could imitate her!"
} 
perfect paradigm of humility, inwardness, obedience, and chastity. Religious women attempted to imitate not only her virtues, but also her relationship with Christ. A nun...felt herself to be a spiritual mother of the child in imitation of Mary's motherhood."2 Although referring to the medieval period, Hale's assertion of how nuns looked to Mary as a model has clear relevance to the Carmelites of Beaune since they too modelled their lives on Mary's example, including their adoption of the role of mother. This chapter explores the ways in which Mary's motherhood was emphasized in documents from the convent in Beaune. The aim here is to explore the ways in which the Discalced Carmelites of Beaune imitated Mary's motherhood through mental and emotional exercises as well as corporal behaviours.

This chapter is divided into four sections. It begins with an analysis of the representations of Mary's motherhood in the Beaune documents. This offers a view of the particular ways in which Mary's motherhood was discussed and more importantly, the ways in which the Discalced Carmelites were prompted to feel and act as mothers in imitation of Mary. Identifying these representations enables us to move forward into an analysis of how the nuns interacted with these images and embodied a spirituality based upon the imitation of Mary's motherhood. The nuns practiced or performed imitatio Mariae in three ways: by contemplating Mary's thoughts and emotions, by acting as physical bearers of Christ, and through actions of maternal affection such as embracing and cradling. Through these three kinds of contemplative and behavioural practices, the Discalced Carmelites of Beaune imitated Mary and became spiritual mothers of Christ.

\footnotetext{
${ }^{2}$ Hale, "Imitatio Mariae: Motherhood Motifs in Late Medieval German Spirituality," 19.
} 


\section{“Sa maternité divine:" Representations of Motherhood}

Before understanding the ways in which the Discalced Carmelite nuns of Beaune sought to model their thoughts and behaviour on the example of the Virgin Mary, we must first consider the various representations of Mary within the documents. In this case, we need to look at the ways in which Mary is represented as a mother. This involves looking at the traits that characterized a mother, how and why certain attributes or behaviours were considered maternal and how such ideas sought to create a particular image of Mary. By first asking how the authors of the texts represented Mary, we can then consider how the Discalced Carmelites of Beaune interacted with these representations and how this shaped their devotion to the infant Jesus.

The Beaune documents explicitly state that Mary is to be a model for the Carmelite nuns. Indeed, a1664 manual for Discalced Carmelite novices states that the order was created "pour honorer la glorieuse Vierge, et pour imiter sa saincte vie.", Many levels of imitation exist, and although the Carmelites looked to Mary in a general way in order to learn how to be good Christians and cloistered nuns, they also had recourse to her in specific ways, such as modelling their motherly behaviour on her example. The Beaune documents emphasize a number of specific characteristics related to Mary's maternity. It is evident that the authors made an effort to create a particular image of Mary and her motherhood of the infant Jesus. One of the dominant representations of Mary's motherhood is her pregnancy. The relationship between the infant Jesus and his mother, the characteristics of Mary's life and her thoughts and

\footnotetext{
${ }^{3}$ Préparation à la vie religieuse (Paris: Simeon Piget, 1664), 517. "To honour the glorious Virgin and to imitate her holy life."
} 
feelings during these nine months, are constantly referred to. In a book of canticles written by the Carmelites of Beaune, one nun writes the following of Mary:

vous este un sacrifice
de purete
que la trinite ste
a accepte...
Il vous mes dans son temple
pour Le servir
et Il vous pren pour temple
des ce jourdhuy
mais un temple de grace
et sainteté
pour estre la demeure
du verbe incarne.

Mary is here represented as the temple, the holy place that housed the infant Jesus for nine months. The nun emphasized Mary's relationship with Christ by focusing on the physical connections between them. Other authors likewise drew attention to the intimate relationship between Mary and Christ during these nine months. Elisabeth de la Trinité exhorted her nuns to "onorer letat du st enfant Jesus dans les antrailles de sa tres ste. mere," thus emphasizing the bodily relationship between mother and son. ${ }^{5}$

Mary and Christ were united in a bodily relationship throughout the nine months of pregnancy, but this connection did not end with Christ's birth. Throughout his infancy and childhood Mary continued to nurture and care for the infant Jesus in physical ways. Representations of Mary depict her feeding Christ and holding him in her arms. For example, Amelote writes in his vita of Marguerite du Saint Sacrement that the nuns

\footnotetext{
${ }^{4}$ Beaune, AM, Archives du Carmel, 29, "Premier livre des cantiques du Carmel de Beaune," 15-16. "You are a sacrifice of purity that the Holy Trinity accepted...He places you in His temple to serve Him, and He takes you as His temple from this day forward, but a temple of grace and holiness, to be the residence of the word incarnate."

${ }^{5}$ Beaune, AM, Archives du Carmel, 11, "Petit recueil de grâces qu'il a plu au St. Enfant Jésus départir à sa petite épouse," 84 . "honour the state of the infant Jesus in the womb of his most holy mother."
} 
should adore the infant Jesus "prenant le lait de sa sainte Mere." dedicated February 25, 1647 to honouring the infant Jesus being nourished by Mary's milk. ${ }^{7}$ This imagery continues in the following account:

apres la ste. Communion le St. Enf. J. s'apparut à Elle [Marguerite du Saint Sacrement] entre les bras de sa Ste Mere qui lui fit connaitre quelq. chose de L'Etat et de la dignité de sa tres Ste. Mere lorqs quelle lui donnait son precieux laict et lui dit que lors quil le prenait il operait en Elle une vie de grace et de purete et quil se donnait et communiquait a Elle dune maniere divine et admirable et que toutes les graces et faveurs quil lui avait communiquée recevant son St. Lait etait maintenant le lait dont Elle lui nourrissait. ${ }^{8}$

This intimacy between Mary and the infant Jesus demonstrates the intense physical connection between mother and son. Through the act of nursing the infant Jesus, Mary received dignity, purity and grace. As we will explore later in this chapter, this maternal behaviour is in fact not imitated by the Carmelites of Beaune. There are no references to the nuns spiritually nursing the infant Jesus. Despite this, the representation of Mary as a nurturing, provisioning mother offers the nuns an example of Mary's physical relationship with the infant Jesus. Though they may not imitate this particular aspect of Mary's intimacy with the Christ-child, the nuns look to her as an exemplar of motherly attention and care for the infant Jesus in a variety of other ways.

Expressions of maternal affection are also depicted in the material culture and visual representations within the Beaune convent. Although there are no references to

${ }^{6}$ Denis Amelote, La vie de Soeur Marguerite du Saint Sacrement, religieuse Carmélite du monastère de Beaune (Paris: Pierre le Petit, 1655), 355. "taking the milk of his holy mother."

${ }^{7}$ Beaune, AM, Archives du Carmel, 2, "Copie d'un fragment des 'Mémoires de la Vie," 23.

${ }^{8} \mathrm{Ibid}$. "after holy communion, the holy infant Jesus appeared to her in the arms of his holy mother who made known to her something of the state of dignity of his most holy mother when she gave him her precious milk and said to her that when he took it he worked within her a life of grace and purity and that he gave himself and communicated to her in a divine and admirable way and that all of the graces and favours that he communicated to her while receiving her holy milk were now the milk with which she nourished him." 
images of Mary feeding her son, there are a number of references to paintings and statues of Mary and the infant Jesus. These vierge à l'enfant recall Mary's tender motherly care for her son. Dom Jacques' letter to Marguerite suggests that there were paintings of this sort in the Beaune convent, since he recommends certain prayers to her which begin with the stipulation, "mettez-vous en posture dévote devant l'image de la sainte Vierge et contemplez ce saint Enfant entre ses bras," ${ }^{, 9}$ or "jetant les yeux sur l'image de l'Enfant Jesus entre les bras de sa sainte Mère." ${ }^{10}$ The convent also housed a statue of Mary cradling the infant Jesus in her arms (Fig. 1). Made in the seventeenth century for the Carmelites of Beaune, this almost life-sized statue was a powerful image of Mary's intimate maternal care for the infant Jesus. Such images and statues of the Virgin Mary cradling her infant son drew attention to the physical relationship between Mary and the infant Jesus and called upon the viewer to imitate this maternal affection.

Moreover, other statues served to remind the nuns that the infant Jesus was indeed a child who required care and attention. While many nuns had their own little wax figure of the infant Jesus, the most significant statue was sent to the nuns by a lay man, Gaston de Renty, in 1643 (Fig. 2). This statue was the object of devotion and maternal attention, as the nuns would dress it in different clothes depending on the liturgical season. This statue, in addition to that of the Virgin and child, reinforced the image of the infant Jesus as a child that they needed to care for, an infant in need of its mother.

\footnotetext{
${ }^{9}$ Marguerite du Saint Sacrement: Correspondance (lettres reçues), 182. "Place yourself in a devout position in front of the image of the Blessed Virgin and contemplate this holy infant in her arms."

"Ibid., 188. "looking at the image of the infant Jesus in the arms of his holy mother..."
} 


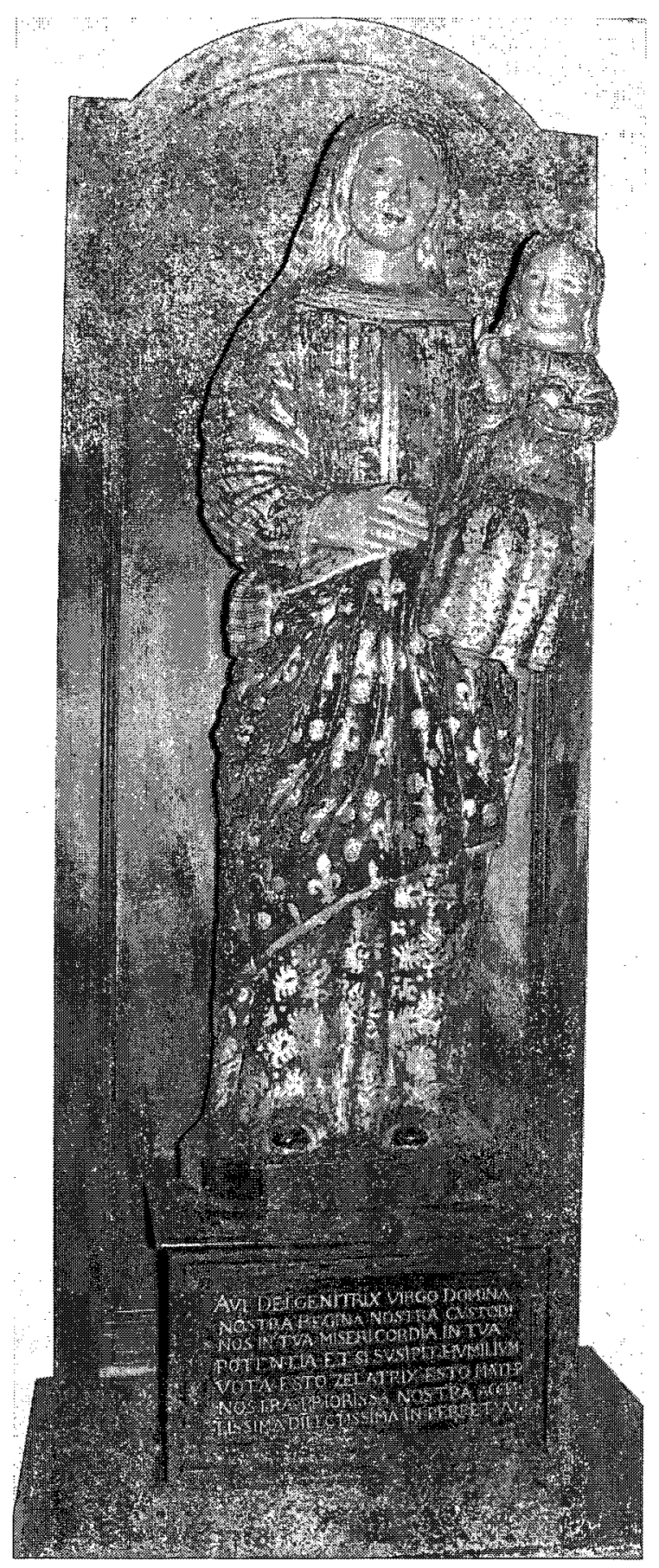

Fig.1. Statue of Mary and the infant Jesus, Beaune convent, seventeenth century. The engraving below reads: "Hail Virgin Mother of God, Our Lady, Our Queen, keep us safe in your mercy, in your power, and if you accept the prayers of the lowly, be zealous, be our mother, our most accepted and beloved prioress forever." 


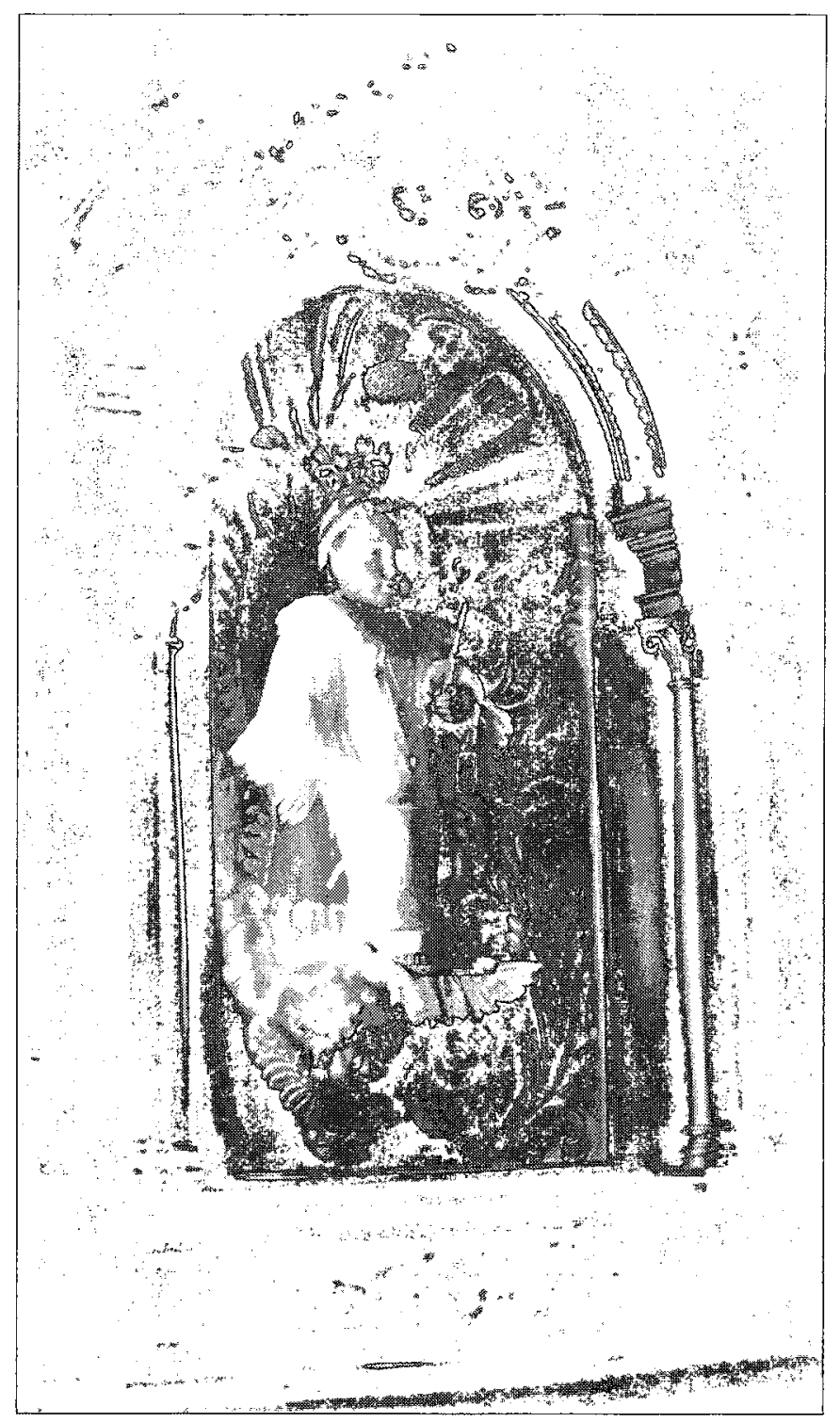

Fig. 2. "Roi de Grâce" statue of the infant Jesus given to the Discalced Carmelites of Beaune by Gaston de $\mathbb{R e n t y}$, Beaune convent, 1643 . We cam see that the infant Jesus is clearly depicted as a child but he is also represented as a king, as evidenced by his staff and his crown. Although the Discalced Carmelites adored him as an infant, by virtue of being God, he was also their king. Here the statue is clothed in white gamments. The statue itself is engraved and painted, with a red background and gold embroidery. The jewels and necklaces that adorn the statue are ex-votos, gifts of thanks for prayers believed to be answered by the infant Jesus. This act of thanksgiving was practiced in the seventeenth century and continues to this day. 
In La vie de Soeur Marguerite du S. Sacrement, Denis Amelote wrote that the nuns were to submit themselves to Mary in honour of her divine maternity, which rendered her the most honoured of all women. " Amelote emphasized Mary's experiences during her pregnancy and encouraged the nuns to constantly recall her intimate relationship with the infant Jesus during this time. This leads to another representation of Mary's motherhood, which are her dispositions. The meaning of this term is ambiguous; however its use seems to suggest that it refers to the inner life: feelings, thoughts, emotions, states of mind. This term is used when referring to the mental or emotional state of Mary and Joseph during certain events such as the birth of the infant Jesus and the flight into Egypt. In this case, the author draws attention to Mary's emotions and states of mind during the nine months in which she carried the infant Jesus, as well as throughout his infancy.

Throughout La vie de Soeur Marguerite, Amelote refers to "les dispositions de la tres sainte Vierge," specifically with regards to the Incarnation and the nine months of pregnancy. ${ }^{12}$ When the Carmelites imitated Mary's dispositions they did so in an interior way, through contemplation rather than physical behaviour. They were encouraged to recall Mary's emotions and state of mind during her pregnancy and throughout her son's infancy and foster the same feelings within themselves. Although Mary's dispositions are not specified it is clear that they were considered to be of significance and excellent subject matter for contemplation and imitation. Later, through a deeper analysis of the

\footnotetext{
${ }^{11}$ Amelote, La vie de Soeur Marguerite, 317. The term domestiques is used frequently to refer to the nuns who have dedicated themselves to the infant Jesus. This is closely linked, and likely inspired by Pierre de Bérulle's spirituality. Bérulle instituted a vow of servitude to Jesus and Mary for the Discalced Carmelites of France. This reflects a spirit similar to Bérulle's interpretation of infancy and childhood as a state of lowly nothingness. We can see here the emphasis on the attitude of nothingness and servitude towards the divine.

${ }^{12}$ Ibid., 321. "the dispositions of the most Blessed Virgin."
} 
ways in which the Carmelites of Beaune were encouraged to mimic Mary's dispositions, we will gain a better understanding of what the nuns were to imagine Mary thought and felt.

Mary's dispositions were related to her virtues. She was often described as silent and humble. ${ }^{13}$ Amelote writes that the nuns were to give themselves to Mary "pour la servir, elle et son Fils Enfant, et à ce dessein s'exerceront en la pratique d'une tres grande simplicité, d'une grande douceur, et d'une profonde humilité". ${ }^{14}$ Simplicity, gentleness and humility are represented as important attributes of the Virgin Mary and the qualities that the Carmelites are to develop. Since these qualities are seen as connected to serving not only Mary but her son as well, we can infer that these qualities were related to her maternity. As Hale explains, "imitating her virtues - chastity, humility, and world renunciation - prepares one to become a spiritual mother." 15 These representations of Mary's virtues encouraged the nuns to cultivate the same qualities within themselves and therefore prepare to become mothers of the infant Jesus.

Not only was Mary depicted as simple, gentle and humble, but she was also seen to have lived "la vie retirée et solitaire" during her pregnancy. ${ }^{16}$ The emphasis on these specific qualities and Mary's solitary life during her pregnancy may have something to do with early modern ideas and practices regarding confinement. As they approached the later stages of pregnancy, women entered a period of relative seclusion and privacy to prepare for birth. Perhaps the references to Mary's "withdrawn life" are a reflection of

\footnotetext{
${ }^{13}$ Jean- François Senault, La vie de la Mère Magdeleine de S. Joseph, religieuse Carmélite déchaussée, de la première règle selon la réforme de Saint Thérèse (Paris: P. Le Petit, 1670), 538.

${ }^{14}$ Amelote, La vie de Soeur Marguerite, 317. "to serve her, she and her infant son, and with this intention practice great simplicity, gentleness and profound humility."

${ }^{15}$ Hale, "Imitatio Mariae: Motherhood Motifs in Late Medieval German Spirituality," 64.

${ }^{16}$ Amelote, La vie de Soeur Marguerite, 322. "the withdrawn and solitary life."
} 
these attitudes towards how pregnant women should behave. Even after the birth of Christ, Mary along with Joseph and the infant Jesus lived "la vie cachée" hidden from the rest of the world. ${ }^{17}$ This emphasis on the secluded life of Mary and the Holy Family more broadly, provided the Discalced Carmelites with a model for the cloistered life. Within this hiddenness and seclusion, the nuns were to mimic the life of the Holy Family. The similarities between Marguerite and Mary are emphasized in the accounts of the interactions between Marguerite du Saint Sacrement and the infant Jesus. This is not surprising as Mary was upheld as the perfect mother of Christ. If nuns are to act as his mother, Mary is clearly the ideal model for how to do so. The author of the Petit Recueil, Elisabeth de la Trinité, constantly emphasized Mary's qualities of purity, humility and innocence which were continually fostered within Marguerite as a result of her interactions with the infant Jesus. With each encounter with the infant Jesus, Marguerite became more and more like Mary, sharing in the virtues and graces bestowed upon her by her son. Just as he gave Mary the grace of purity, so too will the infant Jesus purify Marguerite, in order for her to become more like his mother and therefore able to properly adore him.

Although Mary was more prominently depicted as a model for motherhood, Joseph was also represented as a powerful example of parental affection, for he too cared for the infant Jesus and assisted Mary in her nurturing role. Mary is certainly a more obvious and perhaps more easily imitated model for the Discalced Carmelite nuns, due to her gender and the traditional role she occupied within Catholic devotion. Despite the emphasis on Mary's maternity, Joseph was considered to have an important role in caring for and protecting the infant Jesus. As with representations of Mary's motherhood,

${ }^{17}$ Ibid., 340. "the hidden life." 
Joseph's role as adoptive father is represented in relation to the infant Jesus. Joseph is upheld as a model worthy of imitation because he lived his life in contemplation of Jesus. ${ }^{18}$ Throughout Christ's infancy, Joseph fulfilled the role of adoptive father, or "père nourricier", as a memoire of the life Marguerite du Saint Sacrement describes him. ${ }^{19}$ Joseph is depicted as a caring, nurturing father, who lived "la vie cachée" with Mary and the infant Jesus. ${ }^{20}$ It is his silent, withdrawn life which most characterizes Joseph and it is these attributes that the Discalced Carmelites were to learn from and imitate.

Joseph was honoured due to his relationship with Mary and the infant Jesus. It was because of his relationship with these two that the Discalced Carmelites were to honour him and see him as a guide and model. Indeed, writing the life of Magdeleine de Saint Joseph, Senault explains that "la devotion au bienheureux saint Joseph tenoit un des premiers rangs dans son ame, à cause de ce qu'il est à la Mere de Dieu, et par elle à son divin Fils."21 Additionally, Joseph was praised for his role as the adoptive father of Christ. For example, a memoire of the life of Marguerite du Saint Sacrement explains that Joseph appeared to Marguerite "tenant le St. Enfant J. entre ses Bras." 22 Amelote writes that Joseph adored the infant Jesus "au moment qu'il est venu au monde.,"23 Representations such as these depict Joseph as a tender, caring, adoring father. Unlike representations of Mary, those of Joseph are less direct in terms of their emphasis on imitation. In reading and understanding such sources in the context of broader spiritual

\footnotetext{
${ }^{18}$ Bernard Dompnier, "Les religieux et saint Joseph dans la France de la première moitié du XVIIème siècle," in Religieux, saints et dévotions, France et Pologne, XIllème - XVIlème s., ed. Bernard Dompnier (Paris: Presses Université Blaise Pascal, 2003), 72.

${ }_{19}$ Archives du Carmel, 2, 105.

${ }^{20}$ Amelote, La vie de Soeur Marguerite, 340.

${ }^{21}$ Senault, La vie de la Mère Magdeleine, 548. "the devotion to Blessed Saint Joseph held one of the first ranks in her soul, due to what he was to the Mother of God, and by her to her divine son."

${ }^{22}$ Archives du Carmel, 2, 50. "holding the holy infant Jesus in his arms."

${ }^{23}$ Amelote, La vie de Soeur Marguerite, 351. "at the moment that he came into the world."
} 
and devotional trends of seventeenth-century France we see more clearly that the depictions of Joseph in the Beaune documents attempt to provide the Discalced Carmelites with an additional model of parental care.

Although representations of Joseph depict him caring for the infant Jesus in similar ways as Mary, it is necessary to acknowledge the apparent gender differences. The Discalced Carmelites saw themselves as mothers, not fathers, of Christ. Joseph was Christ's adoptive father and therefore fulfilled the role of his earthly caregiver. Early modern notions of family differentiate between the roles of mother and father, each possessing its own set of qualities, expectations and responsibilities. Although these perceptions of the different roles of mother and father likely influenced the representations of Mary and Joseph, their similarities are more important for this analysis. Mary is upheld as the primary model of motherhood, but since the representations of Joseph often depict him caring for the infant Jesus in more typically maternal ways, the imitation of Joseph cannot be left out of the analysis.

These references to Joseph and his role within the Holy Family are reflective of contemporary trends in Catholic spirituality. They are likewise part of a Discalced Carmelite tradition of devotion to Joseph. Rarely mentioned throughout the twelfth to fourteenth centuries, Joseph became increasingly important to Catholic spirituality during the fifteenth and sixteenth centuries. By the seventeenth century, Joseph assumed a prominent place in the devotional lives of Catholics. Indeed, the seventeenth century has been called the golden age of the devotion to Joseph. ${ }^{24}$ This new emphasis on Joseph, as

\footnotetext{
24 "Joseph (saint)," in Dictionnaire de spiritualité ascétique et mystique: doctrine et histoire, eds. Marcel Viller et al., vol.8 (Paris: Beauchesne, 1974), 1311.
} 
husband, father, and protector, led to the devotion to the Holy Family. ${ }^{25}$ France in particular witnessed an increase in devotion to Joseph and the Holy Family. Seventeenthcentury preachers emphasized specific events in Joseph's life such as his marriage to Mary, the birth of Jesus, and the flight into Egypt. These events were seen to highlight some of Joseph's redeeming qualities: obedience, humility, strength, faith.

Joseph was upheld as a model husband and father, doing everything to protect and provide for his family. In this way, Joseph was considered a model for married people and fathers specifically. But he was also considered a perfect example for religious men and women to follow. Laity and religious alike were encouraged to see Joseph as a model for leading the Christian life. Above all else, Joseph was considered the guide for the spiritual life and the "master of prayer and the guide for souls in the quest of a more intimate relationship with Christ." 26 Joseph was seen to have lived his life in constant prayer, contemplation and in close relationship with the infant Jesus. Those who sought such an intimate relationship with Christ looked to Joseph as an example. Joseph was also depicted as living "la vie cachée" with Jesus. ${ }^{27}$ It was widely believed that he lived his life in obscurity and silence with Mary and the infant Jesus. Devotees were encouraged to follow Joseph's example and imitate this hidden life "in solitude with God.",28

The devotion to Joseph was particularly important in the Discalced Carmelite convents. Teresa of Avila was known to have been a great follower of Joseph, so much

\footnotetext{
25 "Famille (dévotion à la sainte Famille)," in Dictionnaire de spiritualité ascétique et mystique: doctrine et histoire, eds. Marcel. Viller et al., vol.5 (Paris: Beauchesne, 1964), 85.

${ }^{26}$ Dompnier, "Les religieux et saint Joseph," 74.

${ }^{27}$ Henri-Paul Bergeron, "Saint Joseph dans la prédication francaise au XVIIe siècle," Cahiers de Joséphologie 30 (1982), 30.

${ }^{28} \mathrm{Ibid} ., 38$.
} 
so that she dedicated her first convent to this saint. Indeed, Teresa believed that in order to found a monastery, she needed the infant Jesus and Joseph. ${ }^{29}$ Joseph was also considered the patron and protector of many of the Spanish Discalced Carmelite convents. ${ }^{30}$ The founders of convents in France followed Teresa's intense devotion to this saint and of the fifty-eight convents from the seventeenth century, fifteen were under the patronage of St. Joseph. ${ }^{31}$ Additionally, images of St. Joseph abounded in Teresa's convents as in those in France. Images of Joseph with the Christ Child became more common during this period, as paintings from the French carmels supports. ${ }^{32}$ Various types of iconography of Joseph were depicted in paintings, such as the nativity, the presentation in the temple, and the flight into Egypt. Devotion to Joseph became so important in Discalced Carmelite spirituality that one of the objectives of the Carmelites of France was to spread this devotion. ${ }^{33}$ We can see therefore that the representations of Joseph in the Beaune sources are part of the broader trends in the development of the devotion to Joseph. It should not surprise us that Joseph was represented as a model for the Discalced Carmelites, since he was considered to be an example for all Christians to follow. As devout Christians and nuns the Carmelites of Beaune modelled their lives on the example of Joseph and Mary. They thus became members of the Holy Family and devoted themselves to the infant Jesus.

\footnotetext{
${ }^{29}$ Della Croce, L'enfant Jésus au Carmel, 24.

${ }^{30}$ Bernard Dompnier, "Thérèse d'Avila et la dévotion française à saint Joseph au XVIIe siècle," Revue d'histoire de l'Eglise de France 90 (2004): 177.

${ }^{31}$ Pierre Serouet, o.c.d., "Le culte de saint Joseph dans le carmel de France au XVIIe siècle," Cahiers de Joséphologie 29 (1981), 772.

${ }^{32}$ Yves Rocher, ed., Musée du Petit Palais, L'art du XVIIe siècle dans les carmels de France. Paris. (17 novembre 1982 - 15 février 1983), 134.

${ }^{33}$ Serouet, "Le culte de saint Joseph," 773.
} 


\section{Contemplating Mary and Joseph's Dispositions}

“Depuis le douziéme d'Aouit jusqu'au dixhuitieme de Septembre, ils honoreront leur vie domestique, la soûmission du Fils de Dieu, ses services, les emplois que la sainte Vierge et saint Joseph luy donnaient, leur respect en luy commandant, leur douceur, leur silence, leur amour, leur pieté, leurs entretiens, et tout ce qui est inconnu de leur conversation." ${ }^{34}$ La vie de Soeur Marguerite du Saint Sacrement specifies a number of Mary and Joseph's unique qualities. In their relationship with the infant Jesus, Mary and Joseph were respectful, gentle, silent, loving and pious. These attributes seem to be what allowed Mary and Joseph to act as good parents of the infant Jesus. Such characteristics are particularly relevant when one considers that the infant Jesus, as the Son of God, demanded a certain level of respect and piety from those around him, even those charged to care for him. By detailing the specific qualities that enable Mary and Joseph to be good parents of the infant Jesus, Amelote provides the Discalced Carmelites with a template on which to model their own motherly behaviour.

This template encouraged the Discalced Carmelites to imitate the thoughts and emotions of Mary and Joseph. The focus on Mary and Joseph's thoughts and feelings suggests an emphasis on interiority and the importance of one's inner disposition. Indeed, Joseph was traditionally considered the master of the interior life and was often depicted as the perfect model for the contemplative life. On this subject Surin, a Jesuit priest, wrote a letter to a Carmelite nun saying:

He [Joseph] was in the most secret familiarity that one can have with Jesus and Mary, and he has with them

\footnotetext{
${ }^{34}$ Amelote, La vie de Soeur Marguerite, 340. "From the twelfth of August until the eighteenth of September, they will honour their domestic life, the submission of the son of God, his services, the work that the Blessed Virgin and Saint Joseph gave him, their respect in commanding him, their gentleness, silence, love, piety, discussions and all that is unknown of their conversations."
} 
communications and privacies that no one has ever had or will ever have. That is why he is the father of the interior life and the true protector of the souls that have the courage to detach themselves from everything in order to be wholly absorbed in the enjoyment of the divine mysteries. ${ }^{35}$

Joseph was considered the father of the contemplative, interior life and was thus available for those who wished to persevere and succeed in this way of life. This applied to all Catholics, as all were meant to lead a life of prayer, but it applied in a particular way to those who resigned themselves to the world and took up a life of seclusion and constant prayer. As cloistered contemplative nuns, the Discalced Carmelites were to see Joseph as a perfect example of their way of life. Not only did his example aid them in persevering in prayer in a general way, but it also helped them in a very specific way: to orient their prayers and devotions to the infant Jesus.

Living in the company of the infant Jesus as his adoptive father, Joseph was seen to have shared in Christ's most intimate childhood moments. Indeed, Joseph's life beginning from the moment he accepted Mary's pregnancy, was centered upon the Christ-child. And since this child was also God, Joseph lived in adoration and service to him. Bergeron writes the following with regards to Joseph's life of perfect adoration and imitation of Christ: "To become an adoptive child of God, it is necessary to conform to Jesus Christ, which implies that we imitate him, love him, consider him with attention. Now, is it not that which confirms Joseph's perfection?"36 Thus, Joseph was seen to have centered his life, and love, completely on the infant Jesus. His love and adoration led him to imitate the infant Jesus. The theme of becoming children of God by imitating the infant Jesus will be explored in the next chapter, but here we can focus on the depiction

\footnotetext{
${ }^{35}$ Saward, "“The Earthly Home of the Eternal Father," 61.

${ }^{36}$ Bergeron, "Saint Joseph dans la prédication française," 48.
} 
of Joseph as the ideal imitator of the infant Jesus. Through his imitation of Christ, Joseph made his love visible. This adoration and devotion to the infant Jesus was one way in which Joseph exercised his parental role.

The Carmelites were encouraged to imitate Joseph's adoration and imitation of the infant Jesus, but they also mimicked Mary's thoughts and feelings. In preparation for the birth of her son, Mary experienced a number of emotions. Since they saw Mary as their model, the Discalced Carmelites were to accompany her sufferings and joys during her pregnancy. Just as Mary prepared to give birth to the infant Jesus, so too must the nuns join Mary and prepare to become mothers of Christ in their own right. In order to do so, the nuns fostered within themselves the same thoughts and emotions that Mary felt during her nine months of pregnancy.

Identification with Mary's pregnancy was incorporated into the liturgical calendar. Advent and the Nativity of Christ were likely the most important parts of the liturgical year among the Carmelites of Beaune. In addition to the traditional Advent, comprised of the four weeks before the Nativity, the Carmelites of Beaune celebrated their own, longer Advent, which began on the twenty-third of October. This Advent lasted nine weeks, in honour of the nine months that Christ dwelt in Mary's womb. ${ }^{37}$ This extension of the liturgical season of Advent is a clear indication of the significance of anticipating the birth of Christ. The symbolism of the nine weeks of Advent that correspond to Mary's nine months of pregnancy reinforced the nuns' identification with Mary during this time. During these nine weeks of anticipation for the Nativity, the Carmelites imagined themselves to be mothers preparing for the birth of their son. At this time the nuns focused their attention, prayers and actions on uniting themselves with

${ }^{37}$ Le petit office du saint enfant Jésus, 65. 
Mary and Joseph's expectation for the birth of the infant Jesus. Indeed, each day during these nine weeks corresponded with particular prayers and devotions that the nuns performed in order to honour the Incarnation and Mary and Joseph's roles in it.

For example, from the thirtieth of October until the sixth of November, the Carmelites honoured "les dispositions de la tres-sainte vierge au moment de l'Incarnation, et durant les neuf mois qu'elle fut enceinte du Fils de Dieu" and on each of these days they recited their "petit Chapelet" saying "Benedictus fructus ventris tui, et l'Ave Maria.",38 The "petit chapelet" consisted of prayer beads similar to the rosary that the Discalced Carmelites used for prayer. Though the "petit chapelet" had a particular structure (certain prayers were to be said on each bead), the prayers could change, depending on the liturgical season. Here, the nuns prayed specific words from the Hail Mary, "Blessed is the fruit of thy womb," and repeated this prayer in its entirety. The Ave Maria recounts the words that the angel Gabriel spoke to Mary at the Annunciation, praises Mary as "blessed amongst women" and emphasizes her status as Mother of God. By repeating these words, the nuns recall Jesus' miraculous conception and Mary's essential role as mother. By focusing their daily prayers, thoughts and actions on the anticipation of Christ's birth, the Discalced Carmelites were able to more closely identify with and embody Mary's experiences. As Mary did for nine months, the Discalced Carmelites, for nine weeks, lived in constant anticipation of Christ's birth.

As the Nativity approached, the nuns were encouraged to focus more specifically on the pending birth of the infant Jesus. As Christmas drew near, the Carmelites sought to be increasingly united with Mary and Joseph as they made their final preparations. On

\footnotetext{
${ }^{38} \mathrm{Ibid}$., 66. "the dispositions of the most Blessed Virgin at the moment of the Incarnation and during the nine months that she was pregnant with the son of God.", "Blessed is the fruit of thy womb, and the Hail Mary."
} 
December eighteenth, the day of the Expectation, Marguerite du Saint Sacrement is said to have become "unie et liée aux Stes. Dispositions de la Ste. vierge et de St. Joseph et aux desirs vehements quils avaient de la Naissance du St. Enfant Jésus."39 Mary and Joseph possessed a strong desire to see the birth of the Infant Jesus and Marguerite joined in their yearning. In this way, Marguerite, like all Carmelites of Beaune, identified with Mary and Joseph as an expectant mother. With every Advent and every Nativity celebrated, the Carmelites renewed their motherly anticipation for the birth of the infant Jesus.

Just as the Carmelites shared in Mary and Joseph's anticipation of the birth of the infant Jesus, so too did they join them in the joy of his birth. La vie de soeur Marguerite $d u$ Saint Sacrement provides some specific examples of the ways in which Mary and Joseph honoured and adored the infant Jesus. Several times, Amelote draws attention to the feelings that Mary and Joseph experienced in their relationship with the infant Jesus. In explaining the devotions to be performed at specific hours, Amelote writes, "A une heure vous honorerez l'estat auquel la saint Vierge et saint Joseph ont veu et adoré le saint Enfant Iesus, au moment qu'il est venu au monde...Vous honorerez leur joye, leur grace, et leur sainteté en ce moment."40 At the moment of Christ's birth, Mary and Joseph adored the infant Jesus and experienced joy. This joy, grace and holiness that they received at the birth of the infant Jesus was precisely what made them good parents and caregivers of Christ. Indeed, Christ's birth embedded them with these emotions and divine gifts. The Discalced Carmelites mimicked these emotions and dispositions: "Nous

\footnotetext{
${ }^{39}$ Archives du Carmel, 2, 18. "united and bound to the holy dispositions of the Blessed Virgin and of St. Joseph and to the vehement desires they had for the birth of the holy infant Jesus."

${ }^{40}$ Amelote, La vie de Soeur Marguerite, 351. "At one o'clock you will honour the state in which the Blessed Virgin and Saint Joseph saw and adored the holy infant Jesus at the moment he came into the world...You will honour their joy, their grace and their holiness in this moment."
} 
vous adorerons, s'il vous plaist, avec eux, admirable Enfant." ${ }^{41}$ Along with Mary and Joseph, the nuns adored the infant Jesus at his birth, sharing in the happiness of the moment. Mary and Joseph experienced the joy of parents at the birth of their son, and although the infant Jesus was not his biological offspring, Joseph nonetheless experienced intense emotion in this moment. Likewise, although the Discalced Carmelites were not biological mothers of the infant Jesus, they were able to share in the joy of his birth, in their capacity as spiritual mothers of Christ.

Upon the birth of Christ, Mary and Joseph experienced great joy and love for the infant Jesus. The Carmelites of Beaune were to feel the same: "Ce jour là [day of the Nativity] se doit passer dans la participation du bon-heur de la sainte Vierge et de saint Ioseph. " $" 42$ The Discalced Carmelites of Beaune were to share in the joy and happiness that Mary and Joseph experienced. By participating in Mary and Joseph's emotions at the birth of the infant Jesus, the Carmelites participated in the life of the Holy Family. It was as though they were part of the Holy Family, accompanying Mary and Joseph in the expectation of Christ's birth and the Nativity. Rosemary Hale echoes this in her fascinating analysis of imitatio Mariae among the thirteenth-century Helfta nuns of Germany. She writes that "as the worshipper meditates on the humanity of Christ she participates in the life of the Holy Family."43 A manual intended for these nuns suggests that they "'accompany them and help them carry the child and serve them in every way.' In order to do this," Hale continues, "the worshipper models her behaviour on the members of the Holy Family. Identifying with Mary's maternal behaviour places the

${ }^{41}$ Ibid., "We will adore you, if you please, with them, admirable infant."

${ }^{42}$ Institution de la famille du saint enfant Jésus (Lyon: Pierre Campagnon et Robert Taillandier, 1669), 169. "This day must pass in the participation of the happiness of the Blessed Virgin and Saint Joseph."

${ }^{43}$ Hale, "Imitatio Mariae: Motherhood Motifs in Late Medieval German Spirituality," 107. 
worshipper in the closest proximity to the humanity of Christ." ${ }^{, 44}$ This is precisely what the nuns of Beaune did. Through the imitation of Mary and Joseph, the Carmelites "participate[d] in the life of the Holy Family" and became closer to the infant Jesus. ${ }^{45}$

After the birth of the infant Jesus, Mary and Joseph continued in the joy of the Nativity and did everything out of love and honour for the infant Jesus. They constantly sought to care, provide for and protect the infant Jesus. Here too, the Carmelites of Beaune saw themselves as participants in these events, imitating the ways in which Mary and Joseph cared for and protected the infant Jesus. This is explored in more detail in the following sections through an analysis of additional ways in which the Discalced Carmelites of Beaune saw themselves as mothers of Christ. The nuns assumed the role of mother by simulating Mary's pregnancy through the reception of the Eucharist as the body of Christ and by caring for the infant Jesus' physical needs by embracing and cradling him.

\section{“Temples de Grâce:” Becoming Vessels of the Infant Jesus}

A key aspect of becoming and behaving as a mother of Christ was to model the act of conception and carry Christ within oneself, as Mary did for nine months. Just as Mary was considered the temple of Christ, so too were the Discalced Carmelites.

Representations of Mary's physical and spiritual connections with Christ enabled the Discalced Carmelites to more closely mimic Mary's motherhood, by spiritually contemplating and physically performing devotional activities. The work of Carolyn Walker Bynum is particularly useful in understanding how to explore such questions of

\footnotetext{
${ }^{44}$ Ibid.

${ }^{45}$ Ibid.
} 
women's devotional behaviours of this kind. A discussion of her book Holy Feast and Holy Fast will help to provide a framework for an analysis of the ways in which the Discalced Carmelites of Beaune imitated Mary's motherhood through reception of the Eucharist.

Bynum argues that as the bearer of Christ in his earthly form, Mary was portrayed as the receptacle for the Eucharist, which was worshipped as the actual body of Christ. Images of Mary, therefore, were present on tabernacles which housed the Eucharist, sometimes in the form of a statue which opened to reveal the Trinity within, evoking the image of Mary as the receptacle of Christ. ${ }^{46}$ These vierges ouvrante (Fig. 3) though more characteristic of the fourteenth and fifteenth centuries, help to explain the continued emphasis on the idea of Mary as the container or reliquary of Christ. ${ }^{47}$ As early as the thirteenth century, theologians argued that the tabernacle or reliquary, in which the Eucharist was kept, signified Mary's body. ${ }^{48}$ Not only was Mary considered a reliquary but she was also the "relic par excellence" because of her close association with Christ, by conceiving, bearing and feeding him. ${ }^{49}$

The nuns too could house Christ in their bodies as Mary did, by receiving the Eucharist and thus acting as a kind of vessel. Indeed, reception of the Eucharist was highly encouraged as an integral component of Discalced Carmelite life: "Elle [Magdeleine de Saint Joseph] disoit encore, qu'il faloit communier au moins une fois chaque mois, pour se dédier de nouveau à la Mere de Dieu."

\footnotetext{
${ }^{46}$ Bynum, Holy Feast and Holy Fast, 68.

${ }^{47}$ Ibid., 268.

${ }^{48}$ Ibid., 81 .

${ }^{49}$ Ellington, From Sacred Body to Angelic Soul, 237.

${ }^{50}$ Senault, La vie de la Mère Magdeleine, 532. "She said again that it is necessary to receive Communion at least once each month, to dedicate oneself again to the mother of God."
} 


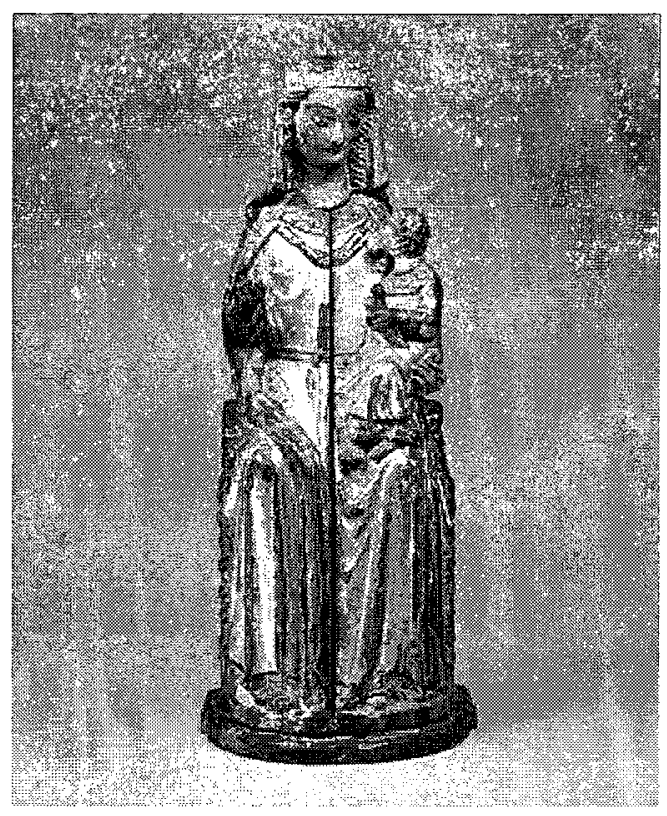

Fig.3. Shrine of the Virgin, Metropolitan Museum of Art, Rhine Valley ca. 1300. Oak, linen covering, polychrome, gilding, gesso. This devotional object, when closed, portrays Mary nursing the infant Jesus and opens (below) to reveal the Trinity inside, thus reinforcing the idea that Mary was the tabernacle of Christ. The body of Christ on the crucifix is broken off as is the dove of the Holy Spirit. Although there is no evidence of such objects within the Beaune convent or other French Discalced Carmelite monasteries, their presence in earlier centuries demonstrates the links between medieval and earlymodern ideas about Mary, Christ and the Incarnation.

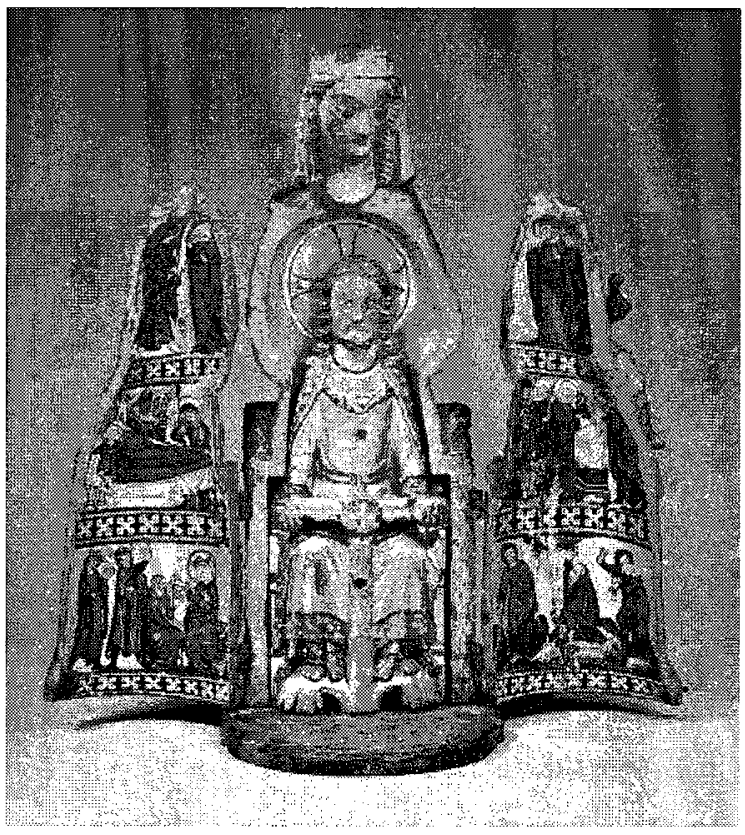


Amelote also writes of the importance of the Eucharist:

Ils visiteront tous les jours une fois le tres-saint Sacrement pour se donner a Dieu et à Jesus son Fils; ils auront recours à luy en ce lieu où il réside pour l'amour des hommes; ils l'adoreront souvent en cet auguste Mystere, et appliqueront une fois le mois leur communion pour les domestiques de cette sainte famille de Jesus. ${ }^{51}$

As this excerpt demonstrates, the Eucharist was clearly central to Discalced Carmelite spirituality. By frequently partaking of the Eucharist, the nuns were able to imitate Mary in their physical reception of Christ. Hale argues that "medieval Christians...associated reception of the host as a re-enactment of the Incarnation, taking place in their own bodies as it did in Mary's. Through reception of the Eucharist they become, like Mary, the vessel wherein the Incarnation occurs." modern period, at least to some extent, as evidenced by the spirituality of the Carmelites of Beaune. Additionally, St. François de Sales, preaching in the late sixteenth and early seventeenth-centuries, urged people to unite themselves with Mary by receiving the Eucharist because in doing so, "one receives Christ as she did." 53 By physically containing Christ through consumption of the Eucharist, the Carmelites continued to act as His mother and persevered in imitating the Virgin Mary.

Although the Carmelites did not conceive and bear children due to their vow of virginity, they were nonetheless able to physically become mothers of Christ, acting as a vessel for his body. Upon receiving the Eucharist, the nuns received the body of Christ into their own body. This behaviour allowed them to imagine themselves as the container

\footnotetext{
${ }^{51}$ Amelote, La vie de Soeur Marguerite, 319. "Every day they will visit the Blessed-Sacrement to give themselves to God and to Jesus his son; they will have recourse to him in this place where he resides for the love of men; they will adore him often in this noble mystery and apply their Communion once a month for the servants of this holy family of Jesus."

${ }^{52}$ Hale, "Imitatio Mariae: Motherhood Motifs in Late Medieval German Spirituality," 34.

${ }^{53}$ Ellington, From Sacred Body to Angelic Soul, 239.
} 
or dwelling of the infant Jesus. Furthermore, this act of physically receiving Christ in the form of the Eucharist was performed often, sometimes daily, since the Catholic Church of this period encouraged frequent communion. Through frequent partaking of the Eucharist, the Carmelites embodied the physical aspect of Mary's maternity. Just as Mary contained Christ in her womb, the Carmelites were to carry him within them upon receiving the Eucharist.

This imagery is repeated throughout the documents from the Beaune convent. Authors frequently refer to the relationship between Mary, the Eucharist, and Christ's express intention in choosing the Discalced Carmelites to act as the temple for his body.

In Elizabeth de la Trinité's Petit Receuil, Christ appears to Marguerite du Saint Sacrement on numerous occasions. During many of their visits, the infant Jesus referred to Marguerite as his temple and dwelling place. On one occasion, the infant Jesus said to Marguerite: "je te prends pour mon temple, mon esprit reposera et demeurera en toi,",54 and "je veux ferre auiourdui une dedicase de ton ame que jai choisie pour estre mon temple et ma demeure eternelle." 55 The infant Jesus chose Marguerite explicitly and repeated his desire for her to become his temple in which he dwells forever. Marguerite du Saint Sacrement certainly had an exceptional and particularly intimate relationship with the infant Jesus; however her experiences in this regard were not merely for her alone. Her example also influenced and edified the other nuns at Beaune. ${ }^{56}$ By looking to Marguerite's experiences with the infant Jesus, and the kinds of things he

\footnotetext{
${ }^{54}$ Archives du Carmel, 11,69. "I take you as my temple, my spirit will rest and remain in you."

${ }^{55}$ Ibid., 103. "Today I want to make a dedication of your soul that I chose to be my temple and my eternal residence."

${ }^{56}$ Historians who study or use vitae as sources agree that they were intended to provoke others to imitation. For example, Rosemary Hale writes that "the vitae were intended to inspire others to model their lives on those of the religious virtuosos represented." (Hale, "Imitatio Mariae: Motherhood Motifs in Late Medieval German Spirituality," 151). We can see therefore that Marguerite's life was recorded, distributed and read in order to inspire other nuns to imitate her life.
} 
communicated to her, the other nuns were meant to see themselves as potential sharers in the graces and experiences of Marguerite. Therefore, the imagery of Marguerite as the temple of Christ was not limited to her alone, but also applied to her fellow sisters. ${ }^{57}$

The idea that all of the nuns at Beaune were meant to be mothers of Christ in this way is expressed in a manual for the confraternity of the infant Jesus, $L$ 'ordre des devoirs et obligations des domestiques et associés de la famille de Jésus Enfant. This devotional tool outlines the particular prayers, devotions, and behaviours required of those dedicated to Christ's infancy: "Cette petite devotion a esté Instituee pour honorer la Ste Enfance de Jesus, de laquelle elle dependra, et par la grace de laquelle, elle subsistera ayant pour chef Jesus, Marie, et Joseph." 58 All three members of the Holy Family watched over, protected, and maintained this association, dedicated to Christ's infancy. The nuns were told that on the day of the Purification "les domestiques de la famille de l'Enfant Jesus, les [the Holy Family] conduiront au temple, et dedans ce st lieu se donneront a luy, et se renouvelleront, et disposeront a estre temple de grace, et de pureté, pour recevoir, et loger ce divin Enfant." 59 Participating in the travels of the Holy Family, the Carmelites entered the temple with Jesus, Mary and Joseph. Moreover, they offered themselves as temples for the infant Jesus in order to be his home. The language used here, "temple," "recevoir," "loger," is of course symbolic, since the nuns are to imagine themselves receiving the infant Jesus within their bodies. Although this is symbolic, in the sense that

\footnotetext{
${ }^{57}$ This is supported by documents from Beaune dedicated entirely to the life of Marguerite and others that explicitly encourage the other nuns to imitate her and use her life as an example for their own.

${ }^{58}$ Beaune, AM, Archives du Carmel, 1, "L'ordre des devoirs et des obligations des domestiques et associées de la famille de Jésus Enfant," 855. "This little devotion was instituted to honour the holy infancy of Jesus, on which it depends and from whose grace, it survives, having as leaders, Jesus, Mary and Joseph."

${ }^{59} \mathrm{Ibid} ., 867$. "the servants of the family of the infant Jesus, will lead them to the temple, and in this holy place they will give themselves to him, renew themselves and prepare themselves to be a temple of grace, and of purity, to receive and house this divine infant."
} 
they were not containing anything physical (unlike when they receive the Eucharist) the nuns still acted as the home or dwelling of the infant Jesus. In addition to this symbolic imagining, it was understood that the infant Jesus was also truly present within each nun, as Catholic spirituality taught that Christ lived within each of the faithful. The lines between the spiritual and physical are blurred here, as the nuns imagined themselves as temples of the infant Jesus, but in doing so, also became the actual dwelling place for him. In this sense, the infant Jesus became physically present within each nun.

This imagery of Mary as the home or dwelling of Christ was not new to the early modern period, nor was it particular amongst the Discalced Carmelites of Beaune. Mechthild of Magdeburg, a thirteenth century German nun, also practiced imitatio Mariae. Her imitation was "based on conceptualizing Mary's womb as the dwelling place of the divine infant and thinking of one's soul as capable of imitating Mary's role." ${ }^{60}$ Hale writes that Mechthild "uses imagery of Mary as the dwelling place or 'house' of God to describe her own experiences. After singing the Ave Maria, she thinks of Mary as the 'glorious temple of God'...In her own performance of the symbols she imitates Mary's virtues in order to become like Mary, a 'house of God.",61 Furthermore, Mechthild "portrays Mary as an abode of Christ and prays, longing to receive the honour of imitating Mary as the dwelling of Christ." 62 All of this imagery and identification with Mary as the abode or house of Christ demonstrates the medieval precedent for the spirituality of the Carmelites of Beaune. Like the thirteenth-century German nuns, the Discalced Carmelites saw Mary as the vessel of Christ and sought to imitate her by seeing themselves as temples for the infant Jesus.

\footnotetext{
${ }^{60}$ Hale, "Imitatio Mariae: Motherhood Motifs in Late Medieval German Spirituality," 86.

${ }^{61}$ Ibid., 89.

${ }^{62}$ Ibid., 93.
} 
The infant Jesus, in his capacity as God, chose Mary to be his mother. ${ }^{63}$

Moreover, he gave her the grace necessary to carry out the task of conceiving and bearing him. Mary was able to perform this great task through the will and aid of Christ himself. It follows then that if the infant Jesus intended for the Carmelites of Beaune to also act as his mother, he will enable them to do so. In their devotions for the twenty-fifth of March, dedicated to the mystery of the Incarnation accomplished within Mary, the Carmelites of Beaune were told:

...concevez une haute et incomparable estime de sa [the infant Jesus'] grandeur, en considerant la vertu du Tres-haut qui couvre de son ombre sa sainte Mere, le Fils de Dieu qui se fait Fils de l'homme, le S. Esprit qui s'épand avec la vertu immense dans l'ame et dans le sein de la sainte Vierge, et qui la rend chef-d'oeuvre de la bonté de Dieu, de sa puissance et de sainteté. Apprenez que ce divin Enfant veut estre formé en vous par les mesmes principes. C'est la bonté et la misericorde infinie du Père, qui vous rend un nouvel homme; c'est ce mesme Pere qui vous transfere de la racine d'Adam en celle de son Fils bien-aimé; c'est le Verbe divin qui vous entre en soy-mesme, et qui vous rend l'un de ses membres vivans; c'est le divin Esprit qui répand en vous la vie de ce Chef: et il faut que l'ame devienne pure et chaste comme la Vierge, pour former en soy cette divine naissance. ${ }^{64}$

The key phrase in this excerpt is "Apprenez que ce divin Enfant veut estre formé en vous par les mesmes principles," which connects Mary's maternity to that of the Discalced

\footnotetext{
${ }^{63}$ Le petit office du saint Enfant Jésus, 184.

${ }^{64}$ Institution de la famille du saint Enfant Jésus, 195-196. “...engender a high and incomparable respect of his greatness, considering the virtue of the Most-high who covers his holy mother with his shadow, the son of God who makes himself son of man, the Holy Spirit who spread himself with the immense virtue in the soul and breast of the Blessed Virgin, and who makes her the masterpiece of the goodness of God, of his power and holiness. Hear that this divine infant wants to be made in you by the same principles. It is the goodness and infinite mercy of the Father that makes you a new man; it is this same Father who transfers you from the roots of Adam into that of his beloved son; it is the divine Word that enters into you and who makes you one of his living limbs; it is the divine Spirit who spread in you the life of this Head and it is necessary that the soul becomes pure and chaste like the Virgin, in order to form within oneself this divine birth."
} 
Carmelites. This emphasizes that the infant Jesus desired to dwell within the nuns in the same way that he was present within the Virgin Mary. All that took place for Mary to conceive and bear Christ also occurred within the Carmelite nuns. Though this depended on the grace bestowed upon them by the infant Jesus, the nuns themselves also had to take particular action. They were required to concentrate on making their soul pure and chaste in the image of Mary. This enabled the infant Jesus to be born within them, allowing them to act as mothers of God and "temple[s] de grâce."

\section{Embracing and Cradling the Infant Jesus}

In an account from 1631, Elisabeth de la Trinité writes of Marguerite du Saint Sacrement's mystical interactions with the infant Jesus. After receiving communion, Elisabeth de la Trinité explains, Marguerite saw Jesus in the arms of Mary. The infant Jesus spoke to Marguerite, saying, "ma fille et ma bien [aimé] toute les fois que tu communiras ie te donnere ung brin de la pureté que ie donnais à ma ste mère cands elle me portait entre ses bras." ${ }^{, 65}$ Again, the next day, Marguerite encountered the infant Jesus who once again spoke of the graces that Marguerite shared with Mary, “je me suis donné à toi ma fille pour te ferre parti[c]iper à la pureté que ie metois en ma ste mere toute les fois quelle ma tenu entre ses bras." ${ }^{, 66}$ These communications between Marguerite and the infant Jesus, repeated throughout this document, reveal much concerning the ways in which the Carmelites of Beaune were to see themselves, along with Mary, as mothers of Christ. They are likewise good examples of the physical and spiritual aspects of Mary's

\footnotetext{
${ }^{65}$ Archives du Carmel, 11, 70. "my daughter and my beloved every time that you receive Communion I give you a bit of the purity that I gave to my holy mother when she carried me in her arms." ${ }^{66} \mathrm{Ibid}$., "I gave myself to you my daughter to make you participate in the purity that I put in my holy mother every time she held me in her arms."
} 
motherhood and the behaviour and dispositions that are to be modelled. In the excerpts quoted above, the infant Jesus explicitly states that he gives himself to Marguerite, as a child, specifically in order for her to share in the purity he bestowed upon his mother each time she held him in her arms. This last aspect, the cradling of the infant Jesus, is a primary way in which maternal imagery is evoked and behaviour encouraged.

The imagery of Mary holding the infant Jesus is dominant throughout the representations of Mary's motherhood. As the excerpts above demonstrate, the act of cradling the infant Jesus was an important image, indeed, a crucial image, in the reconstruction of Mary's maternity. A mother holding her child is likely the most common image of motherhood, and indeed, images of the Virgin Mary throughout the seventeenth-century depict her holding the infant Jesus. Visual representations from Discalced Carmelite convents reveal the prominence of such paintings. One example is a painting of Mary holding the infant Jesus, appearing to Marie de l'Incarnation (Madame Acarie) (Fig. 4). In this image, Mary is surrounded by angels and the infant Jesus calmly sits on her lap, reaching out to Marie de l'Incarnation. ${ }^{67}$ Another painting from the Beaune convent depicts the Nativity scene with Mary cradling the newborn infant Jesus on her lap (Fig.5). These representations of Mary and her son evoke feelings of tenderness and gentleness. The repetition of this image throughout the excerpt above suggests that the nuns reading it were meant to repeatedly imagine the scenario. Additionally, since Mary received graces from her son when she held him, it followed that the nuns too must cradle the infant Jesus in order to share in these graces. In this way, the document is not only descriptive, recounting the interactions between Marguerite and the infant Jesus, but it is most certainly prescriptive, providing the nuns

${ }^{67}$ Rocher, L'art du XVIII siècle, 80. 


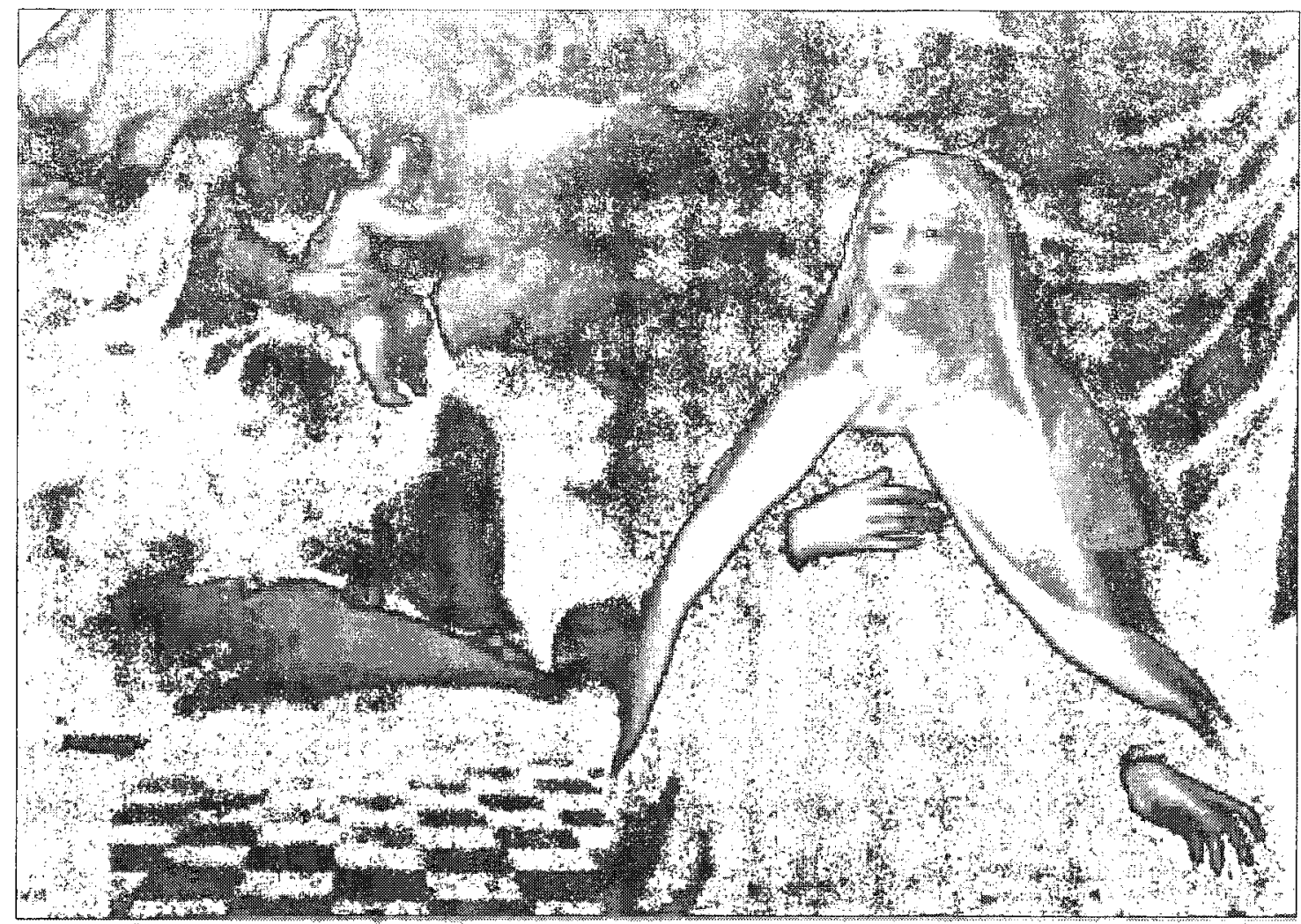

Fig. 4. La Vierge à l'Enfant apparaissant à la Bienheureuse soeur Marie de l'Incarnation (1565-1618), oil on canvas, Collection Carmélitaine, seventeenth century. 


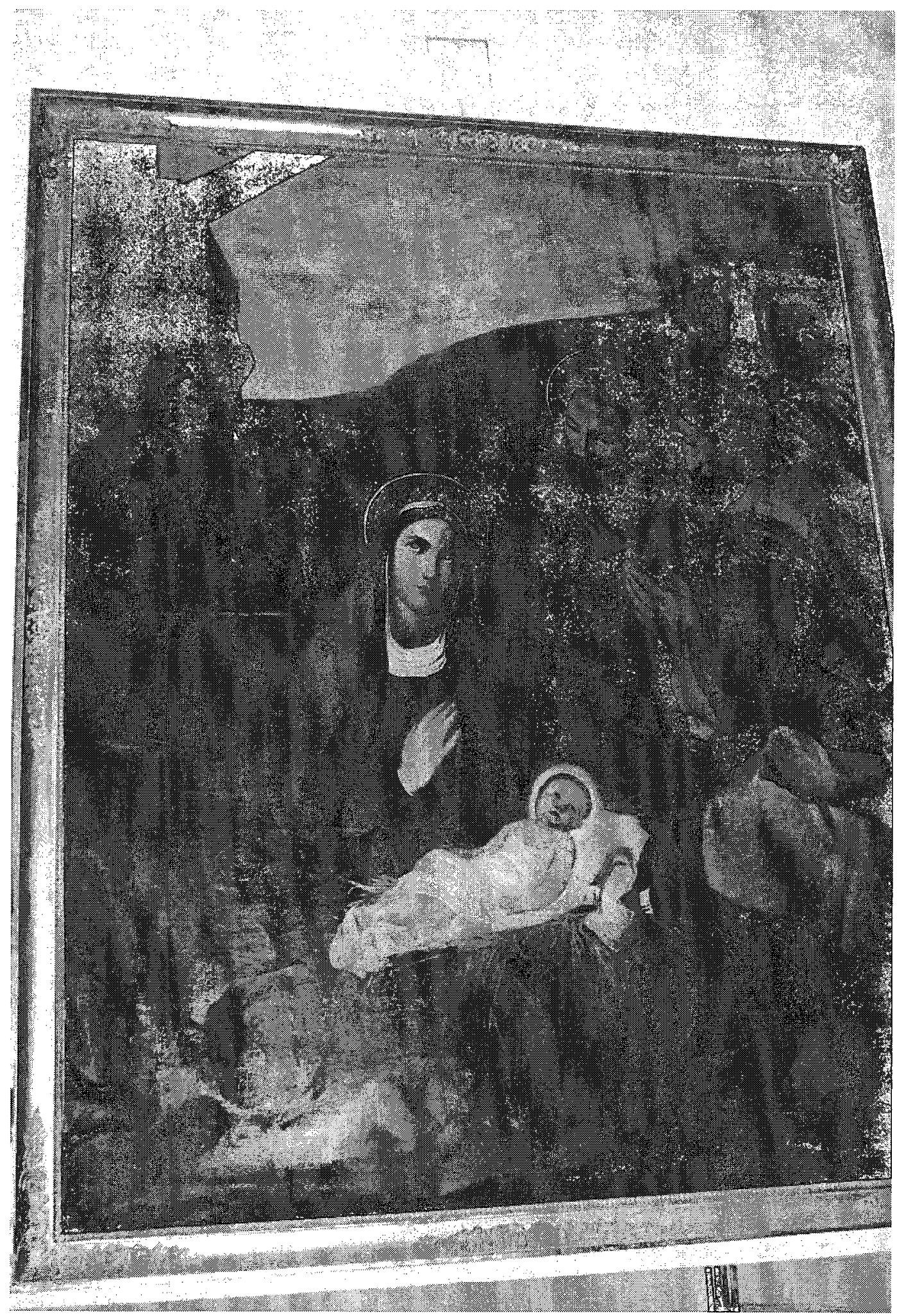

Fig. 5. Painting of the Nativity, Beaune convent, seventeenth century 
with a collection of behaviours intended to guide their imitation of Mary and devotion to Christ. The image of Mary holding her infant son provided the Carmelites with a template of motherly care and attention. In addition, if holding the infant Jesus resulted in receiving grace, the Carmelites were certainly encouraged to imitate this motherly affection. Nurturing motherly behaviour is represented in a number of ways. The nuns were encouraged to clothe, hold and caress statues and paintings of the infant Jesus and his mother.

The letter from Dom Jacques de Sainte Marie, quoted at the beginning of this chapter, provides a good example of the kinds of behaviours that were encouraged among the Discalced Carmelites of Beaune, particularly that of cradling the infant Jesus. Dom Jacques suggests a number of different prayers and accompanying actions to be performed in one's devotion to the infant Jesus. He writes:

Mettez-vous en posture dévote devant l'image de la Saint Vierge et contemplez ce saint Enfant entre ses bras; regardez-le attentivement...Demeurez tant soit peu en silence et soudain faites une saillie comme si l'amour divin vous y portait: Ma Sainte Dame, vous plait-il que je baise la main précieuse de votre sacré fils à l'honneur des chastes baisers que vous lui donniez en sa sainte enfance avec tant de respect. Retirez-vous et mettez la face en terre et comme si la Sainte Mère vous permettait d'approcher, levez-vous et baisez la main du petit Jésus...Baisez derechef sa sainte main diverses fois. ${ }^{68}$

This passage encourages several actions meant to foster proper devotion to the infant Jesus. Again, as in the Petit Receuil, we see the image of Mary holding the infant Jesus

\footnotetext{
${ }^{68}$ Marguerite du Saint Sacrement: Correspondance (lettres reçues), 182-183. "Place yourself in a devout position in front of the image of the Blessed Virgin and contemplate this holy infant in her arms; look at it attentively...Remain this way a little in silence et suddenly make a remark as though the divine love carried you: My Blessed Lady, does it please you that I kiss the precious hand of your sacred son in honour of the chaste kisses that you gave him with such respect during his holy infancy. Withdraw yourself and place your face to the ground as though the Blessed Mother allowed you to approach, raise yourself and kiss the hand of the little Jesus...Kiss his holy hand many times."
} 
as a central component of devotion. This letter suggests that the convent in Beaune routinely displayed such images and furthermore, used them regularly in devotional activities.

This is in keeping with Discalced Carmelite tradition, as Teresa of Avila believed that images helped to sustain and strengthen the spiritual life. She believed that "the figurative representations of Christ and the saints can help the faithful to place themselves in the presence of those that they venerate and pray to." ${ }^{.69}$ John of the Cross echoed this sentiment and clearly emphasized that "images must be a way to address oneself to God, to adore Him and love Him, for this contemplation can easily arouse feelings of devotion. ${ }^{70}$ This applied specifically to the visual representation of the infant Jesus, for it allowed one to access the mystery of the Incarnation. ${ }^{71}$ The use of images, particularly those of the saints, Christ, and Mary, were traditionally regarded in Discalced Carmelite spirituality as powerful tools for devotion. In Dom Jacques' suggestions, the image of Mary and the Christ child is meant to focus one's careful attention, but it is also the inspiration for and the recipient of devotional behaviour, such as kissing and embracing.

After careful contemplation of the image itself, Dom Jacques suggests, the nun must then address the Virgin Mary, asking for her permission to approach and kiss her son's hands. Permission to do this seems to be implicit, for there is no time allotted for waiting for a response from Mary. Dom Jacques immediately suggests that Marguerite kiss the hand of the Infant Jesus. This is an act of adoration and veneration, as Christ is seen as divine and worthy of worship, but this is also the act of a mother, demonstrating her love and care for her child.

\footnotetext{
${ }^{69}$ Rocher, L'art du XVIle siècle, 11.

${ }^{70}$ Della Croce, L'enfant Jésus au Carmel, 63.

${ }^{71} \mathrm{Ibid}$.
} 
Additional actions are encouraged in this letter, which reinforce the argument that the Discalced Carmelites were to perform certain behaviours as a means of adoring and praying to the Infant Jesus. Dom Jacques writes, “embrassez l'image de la Sainte Vierge et son petit Jésus, serrez-les contre votre sein et dites avec confiance: Jésus, mon doux Jésus, et Marie, ma sacrée dame, ne me séparez pas de votre amour et me donnez votre bon esprit." 72 The nuns are told to kiss the infant Jesus just as Mary did during his infancy. Furthermore, the nuns are to kiss Him several times, and when this devotion is complete, they are to embrace the image of the Virgin and child. Such behavioural devotions help the Discalced Carmelites to better imitate Mary in her motherly behaviour towards the infant Jesus. By embracing the image of Mary and the infant Jesus, the nuns perform a physical act of devotion but they also perform the motherly behaviour of embracing one's child.

We see here that physical behaviour corresponds to the mental dispositions of prayer. By embracing the image of the Virgin and Child, a nun performed an act of devotion and love towards them both. In addition, by associating behaviours and corporeal experiences with mental prayer, the ideas contained within the prayer were heightened and the actions were invested with particular meaning. In this case, the action of embracing an image of Mary and the infant Jesus allowed the nun to perform a maternal action (holding the Christ Child) but since Mary is also part of the image, the nun also performs an act of veneration towards the Virgin, acknowledging her role as mother of Christ.

\footnotetext{
${ }^{72}$ Marguerite du Saint Sacrement: Correspondance (lettres reçues), 183. "Embrace the image of the Blessed Virgin and her little Jesus, press them to your breast and say with confidence: Jesus, my gentle Jesus, and Mary, my holy lady, do not separate my from your love and give me your good spirit."
} 
Hale echoes this notion when she argues that "the devotee follows the model of Mary as an act of veneration, but worship of Mary is not the primary motive: intimacy with the Christ-child is...The worshipper who rocks an effigy of the Christ-child...does so to worship Christ as the Incarnation. Imitation of Mary is the vehicle for venerative action directed toward Christ." ${ }^{, 73}$ This last sentence is crucial for understanding the relationship between imitatio Mariae and devotion to the infant Jesus. All of the nuns' imitative behaviour was intended to draw them closer to the Christ-child and performing acts of maternal affection enabled the Carmelites to attain this goal. Like the medieval German nuns, their motherly behaviour of kissing and cradling the infant Jesus, "is predominantly private and mystical in content, intended for a divine audience only. It is a feature of...personal devotion; a spiritual performance. She [the nun] is not simply portraying or impersonating the mother of Christ; rather the boundary between 'imitation' and 'becoming' is blurred. This was the ideal experience of imitatio Mariae inside the cloister." ${ }^{74}$ I would argue that this is precisely the case with the Discalced Carmelites of Beaune. Through maternal behaviour modelled on Mary, the nuns performed private acts of adoration towards the infant Jesus. Such actions of maternal care allowed the nuns to become spiritual mothers. As Hale explains, they are not merely impersonating or pretending to be like Mary, they become Mary through imitative practices.

\section{Conclusion}

After receiving divine communication, Magdeleine de Saint Joseph is reported to have said: “il [God] m'a montré que la Vierge avoit une prérogative d'adorer son Fils en

\footnotetext{
${ }^{73}$ Hale, "Imitatio Mariae: Motherhood Motifs in Late Medieval German Spirituality," 17.

${ }^{74}$ Ibid., 179.
} 
tous les lieux où il est, en mesme temps; et je lui ay demandé qu'elle nous y donnait quelque petit part, et que nous puissions l'adorer par tout avec elle." "75 Mary was, and remains, a watchful, attentive, loving mother. By seeking to imitate her virtues the Discalced Carmelite nuns also sought to become spiritual mothers of Christ. In Mary, they found the perfect example of how to direct their devotion to the Infant Jesus. The Carmelites also looked to Joseph as a means of learning how to dedicate one's life to the infant Jesus. Joseph lived his life in total devotion to the infant Jesus, and as his adoptive father, also exercised an important parental role. Thus, the Carmelites of Beaune could also model their lives on the example of Joseph.

Characteristics such as silence, humility, gentleness, and simplicity provided the Carmelites with a prescription of how to be spiritual mothers. Likewise, by contemplating and uniting themselves to Mary and Joseph's dispositions at the birth of the infant Jesus, the Carmelites shared in their joy as mothers of Christ. The nuns were also to see themselves as physical receptacles of Christ. Just as Mary contained Christ in her womb, the Carmelites were to carry him within them upon receiving the Eucharist, thus acting as temples for the body of Christ. Also in the image of Mary, the nuns fostered thoughts and performed behaviours of caring and nurturing the infant Jesus, just as Mary did, by embracing and cradling him. In this way, the nuns were able to mimic Mary's spiritual and physical motherhood and therefore properly devote themselves to the Infant Jesus. Although perpetually cloistered and bound to vows of virginity, the Discalced Carmelite nuns of seventeenth-century Beaune nonetheless participated in the mysteries of motherhood.

\footnotetext{
${ }^{75}$ Senault, La vie de la Mère Magdeleine, 221. "he showed me that the Virgin has a prerogative to adore her son in all places where he is, at the same time, and I asked him that she would give us some small part, and that we could adore him everywhere with her."
} 


\section{Chapter Three}

\section{Imitation of the Infant Jesus}

Shortly before her death, Marguerite du Saint Sacrement lay in bed, speaking to her confessor. She recalled a particular Good Friday when she was in the nuns' choir, praying at the foot of a Crucifix. Marguerite explained what happened as she prayed: "je suis unie a Jesus Christ agonisant en la Croix, et il me dit que sa passion consomerait mon Corps et mon Exterieur et que son Enfance divine consomerait mon Interieur."1 Marguerite therefore participated in Christ's sufferings and in his childlike qualities. Indeed, becoming like Christ was at the center of the Discalced Carmelite spirituality of Beaune. Imitating Christ in order to model one's life on his, meant to imitate aspects of his Passion and his divine infancy. The ways in which the Discalced Carmelites of Beaune embodied this spirituality and practiced imitatio Christ is the subject of this chapter.

The nuns of Beaune placed the infant Jesus at the center of their spiritual lives. Thus, Marguerite du Saint Sacrement told her sisters that, "il faut que nos coeurs n’appartiennent jamais qu'au petit Jésus et ne soient preoccupés ni remplis que de lui seul."2 Marguerite is clear that the heart of the spiritual life must be the infant Jesus. All of one's thoughts and actions should center upon him alone. When they practiced Christ's childlike qualities, they did this following the example of how he lived during his childhood. When they united themselves to Christ's suffering, they also saw

\footnotetext{
${ }^{1}$ Archives du Carmel, 2, 42. "I am united with Jesus Christ, dying on the cross and he tells me that his Passion will consume my body and my exterior and that his divine infancy will consume my interior." ${ }^{2}$ Marguerite du Saint-Sacrement: Correspondance, lettres écrites, 36. "It is necessary that our hearts belong only to the little Jesus and are neither preoccupied nor filled but with him alone."
} 
themselves as imitators of the infant Jesus, who knew from the beginning the Passion he would endure. ${ }^{3}$

This chapter explores the ways in which the Discalced Carmelites of Beaune sought to imitate the infant Jesus by developing his childlike qualities, uniting themselves to his Passion and suffering. It also examines the ways in which Christ's infancy was incorporated into an imagining of the Passion. The nuns imitated Mary and to a lesser extent, Joseph, in order to become mothers of Christ. Doing so enabled the nuns to immerse themselves in Christ's infancy and the nature of his life with Mary and Joseph during his early years. After doing so, the nuns could then turn towards becoming like the infant Jesus, to imitate him in all of his childlike obedience and innocence. But they were not only encouraged to imitate the divine infancy. Imitation of Christ's Passion and suffering was also encouraged and was intimately linked with his childhood. Only when the nuns embraced the infancy and the Passion did they truly begin to mirror their lives on that of the infant Jesus.

Before a nun could model her life on Christ's example, she first had to know certain particulars about his life and his characteristics. In the documents from the Beaune convent, representations and descriptions of the infant Jesus are plentiful. These depictions offered the Carmelite nuns a distinct image of who the infant Jesus was and his relationship with them individually and collectively. Through these sources we can gain an understanding of the kinds of attributes and behaviours of the infant Jesus as imagined by those devoted to him. This will later enable us to explore how the Discalced Carmelites engaged with these representations in order to fulfill their aim of imitating the infant Jesus.

\footnotetext{
${ }^{3}$ The connection between the infancy and the Passion will be discussed in more detail later in this chapter.
} 


\section{“L'enfance spirituelle:” Representations of Childlike Qualities}

Il [Christ] veut qu'elles se disposent par l'humilité d'esprit, par l'obeyssance, par la douceur et par la patience. Il regnera, dit l'Ange à la Vierge, en la maison de Iacob, c'est à dire, dans les ames dociles, patientes, humbles et laborieuses comme Jacob: ce sont les vertus que doivent pratiquer les devots de l'Enfant Jesus. Car le Pere eternel qui vous le propose pour l'objet de vos adorations et de vos soûmissions, vous le propose principalement pour l'objet de vos imitations. ${ }^{4}$

This excerpt from Institution de la famille du saint enfant Jésus reveals a number of essential virtues that should be practiced by those devoted to the infant Jesus: humility, obedience, gentleness, and patience. The author also adds submission and silence to this list. ${ }^{5}$ Since they are specifically emphasized these characteristics evidently play an important role in the Carmelite spiritual life. The manual explicitly states that while God offered Christ to be the object of adoration and submission, he offered him primarily as the object of imitation. Above all other interactions and relationships with the infant Jesus the Discalced Carmelites were to see him as the model for their lives. They were encouraged to imitate particular characteristics and virtues that the infant Jesus practiced throughout his life in order to enter into a closer, more intimate relationship with him. Giovanna della Croce affirms this when she writes that the infant Jesus "entered into the history of Carmel with the little Jesus of Beaune to indicate the supreme goal of the Order: to make oneself small like this infant at Bethlehem, to attain, in the spirit of childhood, the sublime summit of Mount Carmel." ${ }^{\circ 6}$ The entire life of a Discalced Carmelite nun focused on developing "l'esprit d'enfance," of becoming like the infant

${ }^{4}$ Institution de la famille du saint enfant Jésus, 9-10.

${ }^{5}$ Ibid., 10. "He wants them to prepare themselves by humility of the spirit, by obedience, by gentleness and by patience. 'He will reign', said the angel to the Virgin, 'in the house of Jacob', that is to say, in docile, patient, humble and industrious souls like Jacob: these are the virtues that the devotees of the infant Jesus must practice. For the eternal Father who offers him to you as the object of your adorations and your submissions, offers him to you principally as the object of imitation."

${ }^{6}$ Della Croce, L'enfant Jésus au Carmel, 140. 
Jesus, whom they so adore. The infant Jesus was so much the center of their lives, that to become like him was the ultimate aim.

This "esprit d'enfance" stemmed from the contemporary focus on Christ's humanity and an emphasis on the individual's nothingness, particularly in relation to God. The spirituality of the école française was based on the principle that man is nothing, but has the capacity to receive God and unite oneself to him through prayer. This acknowledgement of one's nothingness in face of God provoked an attitude of profound respect and adoration. ${ }^{7}$ Part of this awareness of one's nothingness and separation from God was the belief that in order to bridge the gap between oneself and God, an individual must center their life on Christ. By putting Christ at the center the distance between the individual and God is diminished. Christians had only, "cover oneself with Our Lord and in the example of Jesus Christ, eliminate within oneself all subject of interest other than God." "This christocentric focus involved conforming one's life to the life of Christ, by imitating not only his Passion and suffering on the cross, but also to become, like him, a child of God and to model one's life on the example of Christ's infancy. ${ }^{9}$

This is also demonstrated in the manual for the confraternity of the infant Jesus. Institution de la famille du saint enfant Jésus includes a collection of prayers to be performed on the twenty-fifth of each month. One prayer to the infant Jesus reflects upon Christ's assumption of human form as a child and that he did this out of love for humanity. After recounting the ways that God showed his love for humans through his Incarnation, the author writes the following prayer:

\footnotetext{
${ }^{7}$ Ibid., 125.

${ }^{8}$ Ibid., 126.

${ }^{9}$ Ibid.
} 
Que ie m'oublie moy-mesme: car vous vous oubliés pour moy, Que je me délaisse et aneantisse, car vous vous anéantissez pour moy...que ie sois l'Image vive de vous mesme, que ie sois fait semblable à vous, me conformant à vos Mysteres, comme vous avez voulu vous faire semblable à moy, vous conformant à mes miseres; que vostre naissance me fasse renaistre. ${ }^{10}$

Just as Christ made himself nothing for the benefit of mankind, the author prays that they may also make themselves nothing for Christ. Because Christ conformed himself to human form, subjecting himself to human suffering, the supplicant prays that they may also discard themselves and be reborn in the image of the infant Jesus. This is the spiritual context in which the Discalced Carmelites of Beaune found themselves in the early to mid seventeenth century. The ideas of Bérulle and those like him penetrated into the French Carmels, informing the devotions fostered within the order. The idea of "I'enfance spirituelle" did not begin among the Discalced Carmelites of Beaune, but as I will discuss throughout this chapter, it certainly took on a distinctly unique form.

The particular "esprit d'enfance" of the Discalced Carmelites is demonstrated through the representations of the infant Jesus in the Beaune documents. Many of these depictions come from the interactions between Marguerite du Saint Sacrement and the infant Jesus. Marguerite and some of her fellow sisters recorded Marguerite's visions and her conversations with the infant Jesus. These writings often describe the infant Jesus, mentioning his appearance, what he says to Marguerite, any objects he holds and the gifts he bestows upon his "petite épouse." " Most of these interactions were recorded

\footnotetext{
${ }^{10}$ Institution de la famille du saint enfant Jésus, 38. "That I may forget myself, for you forgot yourself for me, that I might neglect and annihilate myself, for you annihilated yourself for me. That I might be a living image of you, that I might become like you, conforming myself to your Mysteries, as you wanted to become like me, conforming yourself to my miseries. That your birth will make me reborn."

"Archives du Carmel, 11, 67. "little spouse." The infant Jesus frequently calls Marguerite "ma petite épouse." Other nuns use the term "petite épouse" as well when referring to Marguerite's intimate relationship with the infant Jesus.
} 
by Elisabeth de la Trinité, the Mother Superior of the Beaune convent until 1660. In her entry for December $24^{\text {th }}, 1631$, Elisabeth writes that Marguerite was "tiree dans limmansité divine" and heard the infant Jesus say: “je te donne part à mon sil[e]nse et à la pureté que jai eue dans les entrailles de ma ste mere."12 By sharing Jesus' silence and purity Marguerite was able to partake in his experience as an infant. Purity and silence were therefore important characteristics of the divine infancy. These virtues, in addition to those described above, were the primary attributes of the infant Jesus. This was what the Discalced Carmelites were to foster within themselves in order to become more like the infant Jesus. By focusing on the development of these virtues, the nuns assumed an attitude of childlike innocence, embodying and practicing the qualities of the Christ-child.

\section{“De l'enfance à la croix:” Representations of Christ's Passion}

Though the primary aim of imitating the infant Jesus was to become a child like him, the Discalced Carmelites were also encouraged to unite themselves with Christ's suffering. Indeed, a key aspect of the Discalced Carmelite imitation of Christ was the connection between his infancy and his Passion. According to the école française and Discalced Carmelite spirituality, Christ's infancy could never be separated from his Passion; the child who was born in a poor manger and the man who died on the cross was seen to have been one and the same. In order to more fully understand Christ's act of love for humanity, one had to recall both his birth and his death, never separating one from the other. This connection between Christ's infancy and his Passion informed the ways in which the Discalced Carmelites were encouraged to imitate the infant Jesus. Giovanna

\footnotetext{
${ }^{12}$ Ibid., 79. "pulled into the divine immensity," "I give you a part of my silence and the purity that I had in the womb of my Blessed mother."
} 
della Croce explains this well when she writes: "it is necessary to understand that conformity with the Child of the manger leads to conformity with Christ suffering on the cross. From the Incarnation to the Redemption, from the Infancy to the Cross."13

Devotees of the infant Jesus are therefore encouraged to imitate the life of Christ in its entirety, from the moment of his Incarnation until his death on the cross. A letter from the Beaune convent further clarifies the relationship between Christ's infancy and his Passion:

Qui vénère vraiment l'Enfant Jésus adore en Lui le Rédempteur du monde et ne peut faire autrement que L'adorer aussi dans sa Passion. Les grands dévots de la sainte Enfance nous offrent de ce point de vue de lumineux exemples. De plus, il est exclu de vénérer l'Enfant Jésus sans en invoquer les souffrances - du premier instant de Sa conception à Son dernier soupir sur la croix. ${ }^{14}$

According to this excerpt, devotees of the infant Jesus were bound to also adore him in his Passion and suffering. Since the infant Jesus was seen to be God incarnate and was therefore the "redeemer of the world", his followers had to also adore his Passion, for it was by dying on the cross that Christ truly brought salvation. According to the spirituality of the Beaune convent, the infant Jesus, as God, knew of the sufferings he would endure and therefore by uniting themselves with the infant Jesus, the Carmelites also participated in the divine sufferings. This letter demonstrates that the various aspects of Christ's life, particularly the infancy and the Passion, cannot be adored or even imitated to the exclusion of one another.

\footnotetext{
${ }^{13}$ Della Croce, L'enfant Jésus au Carmel, 143.

${ }^{14}$ Ibid. "Those who truly venerate the infant Jesus adore in Him the Redeemer of the world and cannot do otherwise than adore Him in His Passion... it is out of the question to venerate the infant Jesus without invoking the sufferings - from the first instant of His conception to His last breath on the cross." In citing this letter, della Croce does not indicate any specifics such as date or author, but merely writes "Extrait d'une lettre du Carmel de Beaune."
} 
As the passage above indicates, those devoted to Christ's infancy act as great examples for others to follow, particularly in the way in which they fuse Christ's infancy with his Passion. As with the imagery and embodiment of motherhood, Marguerite du Saint Sacrement offers a good example of the relationship between Christ's infancy and his Passion and its role in the spirituality of Beaune. As mentioned at the beginning of this chapter, the infant Jesus told Marguerite that his Passion and his infancy would consume her. ${ }^{15}$ This is also written about in a letter, probably written by Elisabeth de la Trinite after Marguerite's death, which formed the basis of a document that circulated throughout the other French convents and likely among the laity. In this letter, Elisabeth writes of a number of events from Marguerite's life, including one particular Good Friday, where Marguerite spent three hours attached to the cross in the nuns' choir, suffering as Christ did during his Passion and death. During this time, Elisabeth writes, "son âme fut unie à Jésus Christ agonisant qui lui promit que sa passion consommerait son extérieur et que son enfance consommerait son intérieur." 16 This distinction between the physical appearance of the Passion and the internal nature of the infancy suggests something about the ways in which the nuns imitated Christ.

As we shall see, the nuns imitated the divine infancy by imagining themselves as living in the manger with the Holy Family and by practicing Christ's childlike virtues. By means of such acts of imagination and contemplation the nuns were able to imitate the divine infancy. This can be seen as a more interior form of devotion and imitation. Their identification with the Passion, while involving contemplation of Christ's sufferings, also

\footnotetext{
${ }^{15}$ Archives du Carmel, 2, 42.

${ }^{16}$ Marguerite du Saint Sacrement: Correspondance (lettres reçues), 583. "Her soul was united to Jesus Christ dying who promised her that his Passion will consume her exterior and that his infancy will consume her interior."
} 
involved a more physical response. By imagining themselves enduring the same physical sufferings as Christ, the nuns practiced a slightly more bodily form of imitation.

Although I did not find any evidence of self-flagellation or extreme fasting, I would argue that through the contemplation of Christ's physical suffering and imagining themselves experiencing the same bodily inflictions, the Carmelites of Beaune saw themselves as embodiments of the Passion. Though they may not have inflicted any physical suffering upon themselves, their imitation of Christ's sufferings consumed their exterior because they visualized themselves experiencing the same physical pain.

The connection between the infancy and the Passion is further expressed in the following quote from Elisabeth de la Trinité: “Elle [Marguerite] m'avait dit que le 25 avril Notre Seigneur lui étant apparu, lui avait dit qu'elle serait la première victime de sa crèche et qu'elle devait être bientôt immolée." ${ }^{17}$ Here we see, once again, the connection between Christ's infancy and his Passion, since Christ calls Marguerite "la première victime de sa crèche". This suggests that those who follow and imitate Christ's infancy also suffer as he did. Just as they became participants in his childhood, so too did the nuns partake in his sufferings. Indeed, the words "victime de sa crèche" suggest that one suffers precisely because of one's connection to Christ's childhood. By adoring and imitating the divine infancy, Marguerite also shared in other aspects of Christ's earthly life, such as his suffering.

Moreover, Christ tells Marguerite that she will soon be sacrificed. This vision is said to have occurred on April $25^{\text {th }}$, soon before Marguerite's death and Elisabeth de la

\footnotetext{
${ }^{17}$ Ibid., 587. "She told me that on April $25^{\text {th }}$ Our Lord, appearing to her, told her that she will be the first victim of his manger and that she would soon be sacrificed."
} 
Trinité wrote this letter shortly after Marguerite died in June $1648 .^{18}$ I would argue that the words of the infant Jesus were intended to demonstrate that Marguerite would soon die, and that due to her intense devotion to the divine infancy and her close imitation of the infant Jesus, she was going to be sacrificed as Christ was. The identification of the crèche with suffering emphasizes the deep connection between Christ's infancy and his Passion and Marguerite's devotion to the infant Jesus. This excerpt demonstrates the gravity and intensity with which the Discalced Carmelites understood and practiced their imitation of the infant Jesus. As mentioned before, Marguerite was upheld as a model for others and an exemplar of devotion to the infant Jesus. Even in dying, Marguerite was portrayed as an example of intense and perfect identification with Christ and the fusion of the infancy and the Passion.

\section{Beaune as Bethlehem: Living "la vie cachée" with the Holy Family}

A manual for novices offers some fundamental advice for living as a Discalced Carmelite nun. The manual reminds the novices that they are entering the religious life not to pursue their own desires and inclinations, but those of Christ. The novices were told:

Remarque bien, que les Monasteres de cet Ordre sont Maisons de la Vierge: si donc tu es appellé pour imiter Iesus Christ, regarde quelle vie il a mené dans la maison de sa saincte Mère; ç'a été une vie humble, vie retirée, vie inconnuë, vie cachée et sans bruit, sans iamais se manifester au monde, mais se contentant de traitter en secret avec son Pere Eternel par ses continuelles Oraisons. Telle est...la vie que nous devons nous proposer, puisque nous sommes appellez à la maison de la Vierge,

\footnotetext{
${ }^{18}$ Marguerite died May 26, 1648 at the age of twenty nine.
} 
pour y vivre à la ressemblance du Fils de Dieu humanisé. ${ }^{19}$

This passage emphasizes that the convents of the Discalced Carmelites are houses of the Virgin Mary. This is a common theme throughout all of the Beaune documents. Mary, then, is seen as the true Mother Superior to all Discalced Carmelite convents, acting as the ultimate authority within the convent. The author here assumes that the imitation of Christ is self-evident and does not go into much detail explaining why they should live their lives in this manner. They do, however, specify how the nuns should imitate the infant Jesus. The Discalced Carmelites, like the infant Jesus, live in Mary's house as members of the Holy Family. ${ }^{20}$ In order to know how to imitate the infant Jesus, they were to look to the kind of life he lived in his mother's house. The manual states that Christ led a humble life, withdrawn from any outside disturbances. He was hidden in his mother's house where he spent his time in continual prayer.

The representation of Christ's childhood taking place within the house of his mother functions as an example for the lives of the Discalced Carmelites. As cloistered nuns, these women lived within the convent walls, and as members of a contemplative order, they dedicated their lives to constant prayer - like the quiet, prayerful life of the infant Jesus. Their lives were to resemble his so much that the Discalced Carmelite convents were often compared to Bethlehem. Similarly, Marguerite du Saint Sacrement

\footnotetext{
${ }^{19}$ Préparation à la vie religieuse, 465-466. "Remember well that the monasteries of this order are houses of the Virgin: therefore if you are called to imitate Jesus Christ, consider the life he lived in the house of his Blessed mother. It was humble, withdrawn, unknown, hidden and silent, never showing itself to the world, but contenting itself to be in secret with his Eternal Father through continual prayer. This is the life we must intend to fulfill, since we are called to the Virgin's house, to live there in resemblance of the Incarnate Son of God." This document was written specifically for Discalced Carmelite novices. The specific copy from which this excerpt is taken was found in the Beaune convent, further demonstrating its influence not only among all French Discalced Carmelites (as each convent would likely have at least one copy of this manual) but those at Beaune specifically.

${ }^{20}$ This idea of living as a member of the Holy Family is discussed in the previous chapter and will be further elaborated later in this chapter.
} 
referred to the Beaune convent as a stable, like that in which the infant Jesus was born. ${ }^{21}$ Not only was the Beaune convent depicted as Bethlehem, but Bethlehem and Nazareth, later the home of the Holy Family, were also represented as the convent. As Jacques Roland-Gosselin writes, "[one] lived therefore in Bethlehem and in Nazareth like in the Carmel, and the manger was the monastery the most absorbed in prayer and contemplation." ${ }^{22}$ Bethlehem and Nazareth were therefore viewed as ideal convents, and the manger as the perfect cloister, where one could be immersed in constant prayer and contemplation. Indeed, as Saward points out, theologians of this period emphasized that "the Hidden Life in Nazareth, at the hearth of the Holy Family, is a contemplative life."23 The examples above suggest that the crèche in Bethlehem where the infant Jesus was born was considered a cloister and that the Beaune convent was considered Bethlehem. In this way, the crèche was a model for the cloister. This reciprocal relationship between the convent and the crèche demonstrates the degree to which the nuns considered themselves part of the Holy Family. By seeing themselves as living in the crèche in Bethlehem, the nuns understood that their life must be lived hidden from the outside world.

Indeed, the infant Jesus himself encouraged this association between the cloister and the crèche during one of his many interactions with Marguerite du Saint Sacrement. On September 25, 1646, the infant Jesus appeared to Marguerite and showed her his home in Bethlehem, telling her that the Discalced Carmelite nuns "ne devaient point

\footnotetext{
${ }^{21}$ Marguerite du Saint Sacrement: Correspondance, lettres écrites, 13.

${ }^{22}$ Roland-Gosselin, Le Carmel de Beaune, 157.

${ }^{23}$ Saward, "“The Earthly Home of the Eternal Father," 59.
} 
sortir de cet Enclos et que leur vie fut conforme a son Etat en ce lieu." ${ }^{24}$ Marguerite is thus told that she and her fellow nuns must never leave Bethlehem (their convent) and that their lives must resemble his. It is significant that the word "enclos" is used to describe the physical space of both the cloister and Bethlehem.

Not only did the infant Jesus tell the Discalced Carmelites that their lives were to be lived in the cloister of his crèche, but the nuns themselves sought such a life, by asking the infant Jesus to keep and protect them within the convent. One nun writes:

Venes nous chache sous le voille petit Jesus que vous aves aporté du ciel en la terre Pour y chache vos bien aimé Jesus chache Jesus voillé chache nous donc sous la protection de vostre enfance en benediction. ${ }^{25}$

This canticle expresses one nun's desire to be hidden, veiled, by the infant Jesus. She reflects that the infant Jesus came to "hide" those he loves, and she wishes to receive this blessing of being enfolded in his infancy. We can see here that the nun who wrote this canticle strove to lead her life in claustration and in imitation of the infant Jesus's life in Bethlehem. She, and presumably other nuns, were consciously aware of the connection between the crèche and the convent, and explicitly wrote about being hidden in the cloister of Bethlehem. In this way, the Discalced Carmelites imitated the life of the infant Jesus by living "la vie cachée" with the Holy Family in Bethlehem. ${ }^{26}$

\footnotetext{
${ }^{24}$ Archives du Carmel, 2,16. "must never leave this enclosure and that their life be conformed to his state in this place."

${ }^{25}$ Archives du Carmel, 29, 6. "Come hide us under the veil, little Jesus that you brought from Heaven onto earth, to hide your loved ones, hidden Jesus, veiled Jesus, hide us therefore with blessings under the protection of your infancy."

${ }_{26}^{26}$ Amelote, La vie de Soeur Marguerite du Saint Sacrement, 340.
} 
Moreover, this canticle reveals the various levels, or layers of hiddenness. Not only were the nuns hidden within the walls of the cloister, but their religious habit provided an additional level of claustration. As Figures 6 and 7 demonstrate, the Discalced Carmelites wore clothing that covered their entire body, including their head, with only their face and hands visible. The nuns were therefore "veiled" both by the architecture of their cloister and through their clothing. This canticle refers to Jesus as also veiled, like the nuns, which reveals the nun's perception of the similarities between her life and that of Christ. Through the identification of the cloister with the crèche the nuns saw themselves as participants in the hidden, veiled life of the infant Jesus.

This imagery of the hidden life of Jesus was not specific to the Beaune convent but was emphasized in seventeenth-century French spirituality more generally. As the previous chapter explained, the devotion to the Holy Family began during this time, introducing a new emphasis on Mary, Joseph and the infant Jesus. Theologians from different religious orders, such as Bérulle (Oratory) and Lallemant (Society of Jesus) focused on the humanity of Christ and the Incarnation. Saward suggests that these individuals, "working independently in the same historical period, [set] the stage for a new veneration of the infancy and hidden life of Christ, His family life, those precious yet silent years when He is enfolded in the love of Mary and Joseph."27

Both Bérulle and Lallemant, whose interpretations of the life of the Holy Family permeated the convent walls of Beaune, taught that individuals were called to participate in the "hiddenness" of Christ's infancy. ${ }^{28}$ Lallemant writes that Christ was hidden in all stages of his life: "in the bosom of His Father, in the womb of His mother, in His birth, in

\footnotetext{
${ }^{27}$ Saward, “"The Earthly Home of the Eternal Father," 57.

${ }^{28}$ Ibid., 59.
} 


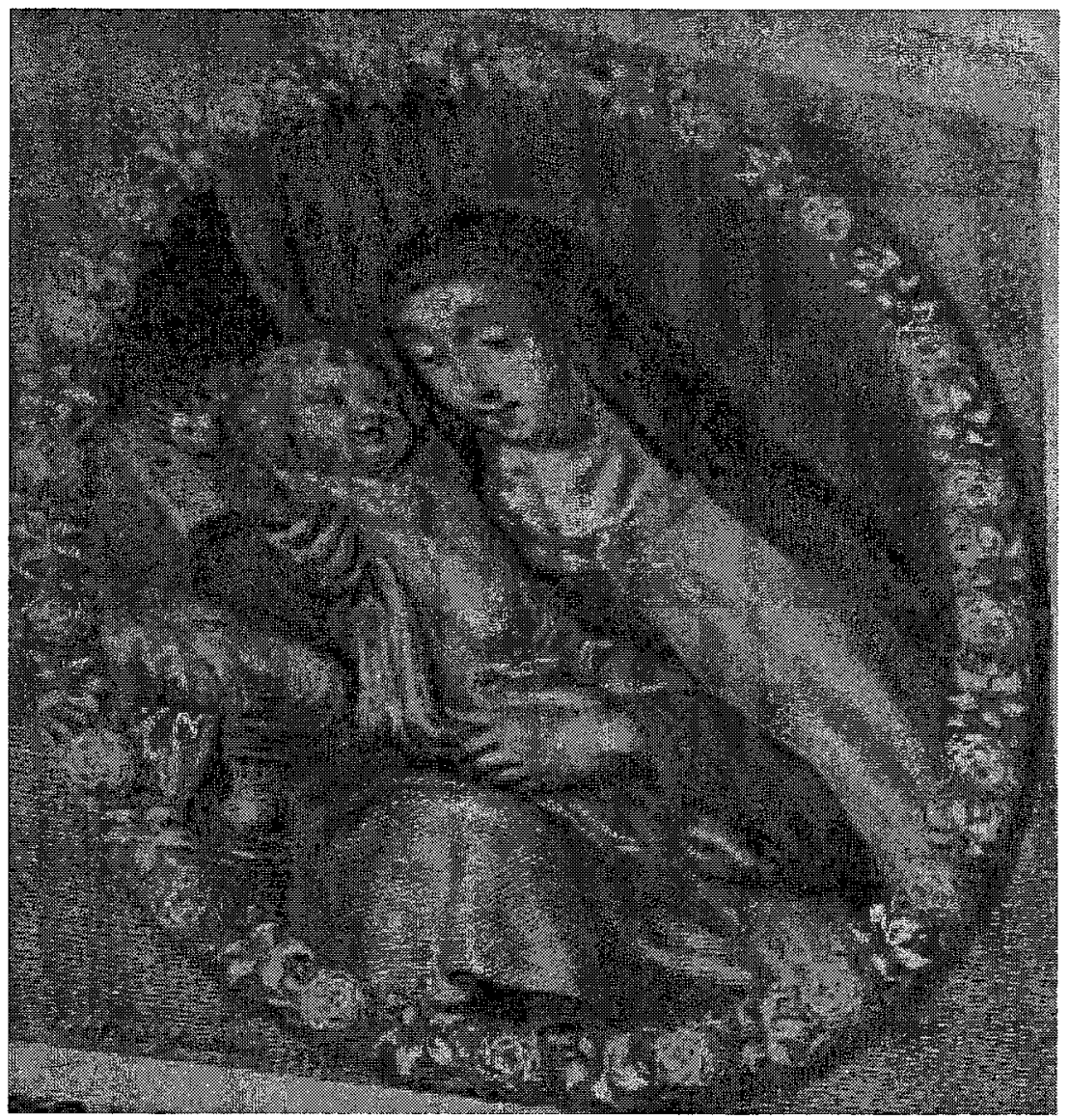

Fig. 6. Engraving of Marguerite du Saint Sacrement and the infant Jesus, Archives du Carmel, 21, 54, seventeenth century. 


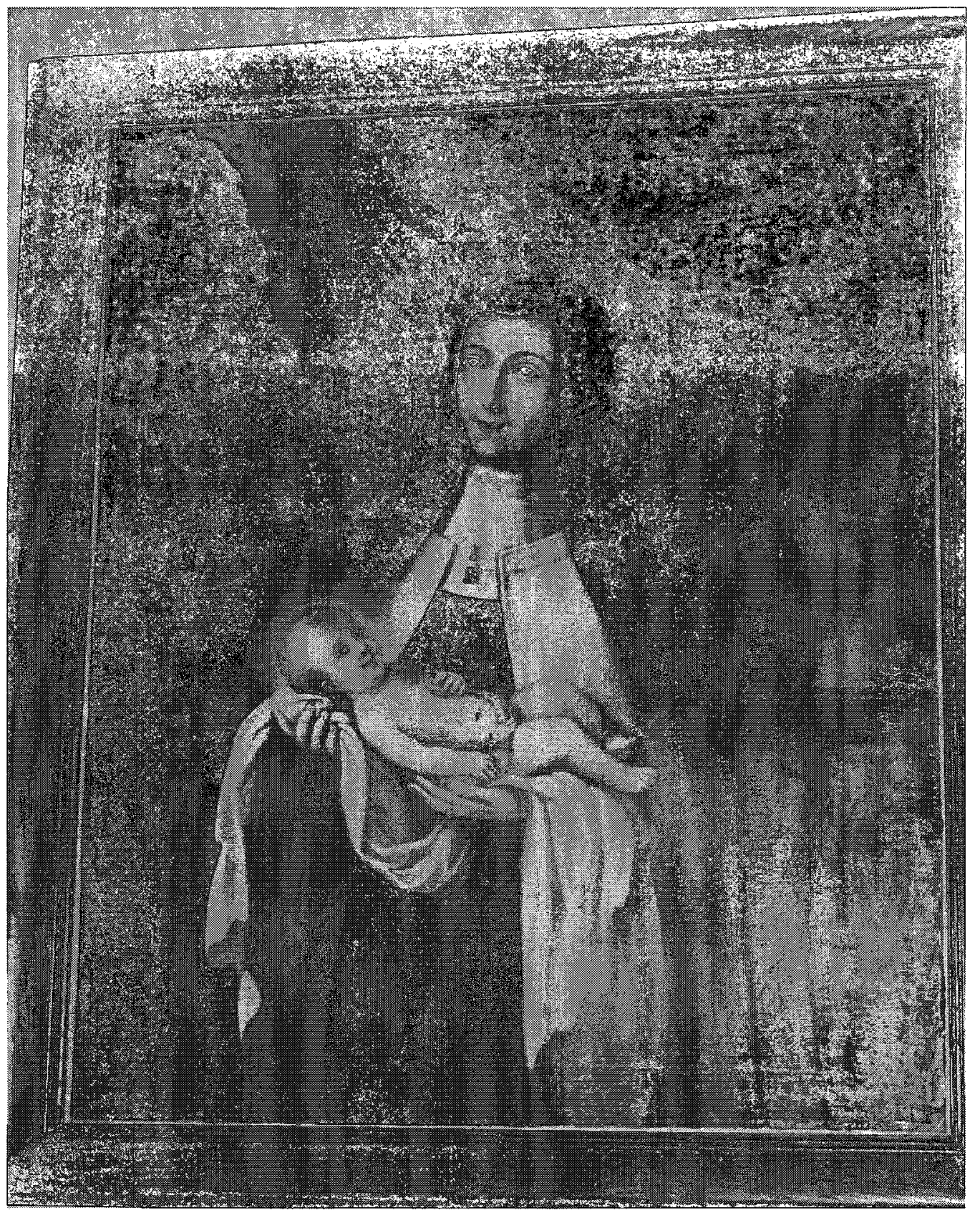

Fig. 7. Painting of Marguerite du Saint Sacrement holding the infant Jesus, Beaune convent, seventeenth century. 
His childhood, in His exile in Egypt, in His dwelling in Nazareth...in the ignominy of His Death...When one loves Jesus Christ one loves to stay with Him." ${ }^{29}$ Lallemant encouraged individuals to follow Christ throughout the stages of his life, especially those early years he spent with Mary and Joseph, and to live in the "hiddenness" of the Holy Family. This is precisely what the Carmelites of Beaune strove to do.

Giovanna della Croce writes that "the path of spiritual childhood... is manifested by humility, obedience...confidant submission to the divine infant." ${ }^{, 30}$ A reading of the Beaune documents supports this claim, for these qualities are frequently repeated and emphasized as paving the way of "l'enfance spirituelle." In fact, these three qualities of humility, obedience and submission formed the foundation of the imitation of the infant Jesus. Within their hidden life with the Holy Family, residing in the Bethlehem stable, the Discalced Carmelites imitated specific aspects of Christ's childhood. The life of the Infant Jesus was often depicted as a life of obedience and submission, both to God and to Mary and Joseph. This is closely related to and depends upon the virtue of humility. Within this environment innocence and simplicity, the essential characteristics of the divine infancy, were fostered. We will now explore the ways in which the Discalced Carmelites of Beaune integrated these characteristics into their own spiritual lives and in so doing, focused their minds and bodies on developing "l'esprit d'enfance" through the imitation of the infant Jesus.

“C'est ce divin Enfant qui nous apprend l'obéissance, c'est notre divin Maître qui...nous enseigne...à être simples et petits comme lui, pour que notre obéissance soit

\footnotetext{
${ }^{29} \mathrm{Ibid}$.

${ }^{30}$ Della Croce, L'enfant Jésus au Carmel, 135.
} 
parfaite." ${ }^{\text {31 }}$ Thus did Marguerite du Saint Sacrement encourage her fellow nuns to learn perfect obedience from the infant Jesus. The desire to become like the infant Jesus by learning from him how to be childlike is at the heart of this statement. Here, Marguerite emphasized the importance of obedience, of submitting oneself to the will of others. The infant Jesus is depicted as being obedient to Mary and Joseph but also, and perhaps more importantly, to the will of God. Through the Incarnation, Christ followed the will of his father during his entire life, even until his death. As a child, Christ lived under the supervision of Mary and Joseph, submitting himself to them. By focusing on the ways in which the infant Jesus lived a life of obedience to God and to his earthly parents, the Discalced Carmelites internalized obedience to their superiors and to God.

But before they could practice obedience, the Discalced Carmelites had to first understand how the infant Jesus lived his life in this way. Throughout the Beaune documents there are references and descriptions of Jesus' early life with Mary and Joseph. One particular account in L'ordre des devoirs et des obligations des domestiques et associées de la famille de Jésus Enfant draws particular attention to the infant Jesus' obedience to Mary and Joseph. The author writes:

Jesus estoit obeissant et assuietty a sa ste. Mere, et a St. Joseph, qui estoient en continuel respect, et reverence devant ce St Enfant, neantmoins comme Il a voulu estre conforme a nous, et nous montrer exemple d'humilité, et d'obeissance Jusques a la mort, et que son enfance ste nous fut un Exemple de toutes vertus, et perfections, Il a voulu estre obeissant a tous, et obeir a sa Ste Mere, et a St Joseph. ${ }^{32}$

\footnotetext{
${ }^{31} \mathrm{Ibid}$. The author does not provide a citation from where this quotation is taken. "It is this divine infant who teaches us obedience, it is our divine Master who...teaches us...to be simple and little like him, so that our obedience may be perfect."

32 Archives du Carmel, 1, 892. "Jesus was obedient and subject to his Blessed mother and St. Joseph, who were in continual respect and reverence before this holy infant, nevertheless, since He wanted to conform to
} 
The infant Jesus chose to submit himself to the earthly authority of Mary and Joseph in order to teach by example the virtue of obedience. As mentioned in Chapter One, seventeenth-century Catholics interpreted the Incarnation in such a way that there was great significance in the act of God becoming not only man but a child. To them, this demonstrated the utmost humility and a state of obedience and submission. This manual for members of the confraternity of the infant Jesus encourages the nuns and laity to see the infant Jesus as an example for their own attitude and behaviour. In doing so, they not only imitate the infant Jesus by submitting themselves to the authority of Mary and Joseph, but they also fulfill the will of God and obey his commands. The author of the manual continues to say that "[le] Père Éternel...vouloit estre glorifié par lobeissance ste et divine de son fils" so that by imitating the obedience of the infant Jesus, the Discalced Carmelites glorify God and please him through their humble submission. ${ }^{33}$

Elsewhere in the Beaune documents we continue to see the connection between obedience, learned from the infant Jesus, and performing the will of God. By submitting themselves to God's will the nuns obeyed him after Christ's example. In her analysis of the letters of Marguerite du Saint Sacrement, Marie-Françoise Grivot explains that Marguerite believed that to follow the infant Jesus completely involved, "absolute detachment of oneself, unconditional and unceasing attachment to the will of God."34 According to Grivot, Marguerite modelled her life on that of Christ in part by submitting herself to the will of God, following his desires, not her own. This is central to the "esprit d'enfance" cultivated within the Beaune convent. The infant Jesus obeyed his earthly

us and show us the example of humility and obedience until death, and that his holy infancy be an example to us of all virtues and perfections, He wanted to be obedient to all and obey his Blessed mother and St. Joseph."

${ }^{33}$ Ibid. "The Eternal Father wants to be glorified by the holy and divine obedience of his son."

${ }^{34}$ Marguerite du Saint Sacrement: Correspondance, lettres écrites, 88. 
parents and heavenly father because the first were in positions of earthly authority and the latter was the divine authority. Similarly, the nuns forgot themselves and after the example of the infant Jesus, cultivated an attitude of obedience to the will of God.

The Christ-like attitude of submission is often connected with innocence and simplicity, a good example of the ways in which the virtues of the infant Jesus are intricately woven together. In a letter to Angélique de la Trinité at the Maçon convent, Marguerite du Saint Sacrement linked the qualities of submission and simplicity as she advised her fellow sister to follow the infant Jesus: "Je vous supplie ma chère soeur de ne point tant regarder les choses qui vous sont mises en l'esprit; il faut que vous négligiez tout cela et que, dans une grande simplicité et soumission, vous vous rendiez à ce que le saint enfant Jésus veut de vous." ${ }^{35}$ Marguerite offered consolation and advice for Angélique who seemed to be having some trouble adapting to the Carmelite life. Marguerite's advice is to forget her troubles and adopt a spirit of simplicity and submission in order to fulfill the plans of the infant Jesus for her life. Grivot comments that simplicity and submission are two words that recur constantly to characterize the “esprit d'enfance" of Beaune. ${ }^{36}$ By turning away from her own troubles and desires and turning towards the infant Jesus, Angélique de la Trinité and all other Carmelites who fervently devoted themselves to the infant Jesus fulfilled Marguerite's simplest and perhaps most powerful statement: "nous ne devons regarder que lui, chercher ni aimer que lui." 37

\footnotetext{
${ }^{35}$ Ibid., 23. "I beseech you my dear sister to no longer look so much at those things which are placed in your spirit; it is necessary that you neglect all of this and that, in great simplicity and submission, you surrender yourself to that the infant Jesus wants of you."

${ }^{36} \mathrm{Ibid} ., 24$.

${ }^{37}$ Ibid., 34. "we must not look but at him, seek nor love but him."
} 


\section{"Victime de sa crèche:" Suffering like Christ}

The Discalced Carmelite nuns of Beaune were not only encouraged to imitate the infant Jesus and develop his childlike qualities, but they were also encouraged to identify with his suffering and Passion. As Institution de la famille du saint enfant Jésus states: “nous sçavons...que l'esprit de son Enfance et de sa Passion ne vieillit ny ne meurt jamais." 38 The manual explains that although these specific events already occurred in the past, their effects and significance have not ceased. Christ was born an infant and passed through adolescence and adulthood culminating in his death on the cross, "mais l'humilité, la pureté, l'innocence, et toutes les vertus du Dieu enfant, la patience, la force, le sacrifice, et tout le merite du Dieu mourant subsisteront aux siecles des siecles."39 The author links Christ's infancy with his Passion, explaining that all of the virtues and qualities of the infant Jesus continue to exist in the Passion of Christ and will always continue to exist.

As the excerpt above explains, Christ's infancy and Passion will never die, that is, they are perpetually remembered and relived by the faithful. These aspects of Christ's life are intricately connected and those who sought to imitate Christ could not overlook this. The words of Giovanna della Croce, quoted earlier, should be recalled: "it is necessary to understand that conformity with the infant of the manger leads to conformity with Christ suffering on the cross." ${ }^{, 0}$ Marguerite du Saint Sacrement is a good example of how conforming to Christ's infancy leads to conformity with his Passion. Considered the most loyal imitator of the infant Jesus, Marguerite never separated the mystery of the

\footnotetext{
${ }^{38}$ Institution de la famille du saint enfant Jésus, 8. "we know that the spirit of his infancy and of his Passion will not age nor ever die."

${ }^{39} \mathrm{Ibid}$. "but humility, purity, innocence, and all of the virtues of the infant God, patience, strength, sacrifice and all of the merit of the dying God, will exist forever."

${ }^{40}$ Della Croce, L'enfant Jésus au Carmel, 143.
} 
Incarnation from the mystery of Redemption. ${ }^{41}$ A letter from Marguerite du Saint Sacrement to Marguerite de Saint-Alexis demonstrates an understanding of the links between the infancy and the Passion. Marguerite du Saint Sacrement advised her fellow nun to have "une grande confiance en sa [the infant Jesus's] bonté et perdez tous vos péchés et tout ce que vous êtes en ses plaies et en son précieux sang."42 Grivot comments that this is the first instance in her letters that we see Marguerite referring specifically to the Passion. She adds that "she meditated on the sufferings and death of Christ so much that she assimilated herself to it; she lived the virtues of the "states" of the infancy in continuity with the sufferings... associated with those of [Christ]." ${ }^{43}$ Imitation of the infant Jesus therefore also involved the imitation of his suffering. It seems that one could not develop "l'enfance spirituelle" without also understanding and imitating aspects of Christ's Passion.

Connections between Christ's infancy and Passion are also emphasized in L'ordre des devoirs et obligations des domestiques et associées de la famille de Jésus Enfant, which outlines the devotional expectations of confraternity members. One passage reads:

les domestiques de l'Enfant Jesus porteront, engravé dans l'Intime de leurs ames, un grand amour et reverence [d]es sentiments que l'Enfant Jesus a eu de sa croix et pour l'Imiter en cet estat, elles revereront avec Joye les occasions ou elles pourront souffrir quelque chose pour luy. ${ }^{44}$

The members of this association are told to imitate the infant Jesus' feelings towards his cross. Indeed, they were to experience joy when an opportunity arose when they could

${ }^{41}$ Marguerite du Saint Sacrement: Correspondance, lettres écrites, 57.

${ }^{42} \mathrm{Ibid}$., 56. "great confidence in his goodness and lose all of your sins and all that you are in his cries and in his precious blood."

${ }^{43}$ Ibid., 57.

${ }^{44}$ Archives du Carmel, 1, 868. "the servants of the infant Jesus will carry, engraved in the intimacy of their souls, a great love and reverence for the feelings of the infant Jesus towards his cross, and to imitate him in this state, they will revere with joy the occasions where they may suffer something for him." 
suffer for Christ. Although it is not stated here, this implies an attitude of obedience, submission and perfect acceptance of his suffering and death. Here we see a certain continuity with the development of Christ's childlike virtues of obedience and submission which also apply to the imitation of his Passion. The Carmelites of Beaune were therefore called to join the infant Jesus and embrace the opportunity to suffer for his sake. In this way, they participated in the pains of his Passion which gave meaning to any suffering they may have endured. Their earthly or spiritual struggles and sufferings gained significance when they were linked to the infant Jesus's acceptance of his death on the cross.

The Carmelites themselves openly shared their desire to imitate the infant Jesus' sufferings. One nun's canticle expressed just this:

$$
\begin{aligned}
& \text { que nous nayon esprit ni vie } \\
& \text { que pour vous servir et aymer } \\
& \text { plus de desir ny d'autre envie } \\
& \text { que de toute nous comsommer } \\
& \text { dans l'amour pur de vtre enfence } \\
& \text { qui nous uni a vtre croix } \\
& \text { et a vos divine souffrance. }
\end{aligned}
$$

The Discalced Carmelites of Beaune believed that immersion in Christ's infancy connected them to the cross and all of the infant Jesus' sufferings. Though this link between Christ's infancy and his Passion may be difficult to fully understand, it is significant that the nuns felt that a connection existed. Significantly, all references to Christ's Passion refer to the infant Jesus. By this I mean that the nuns, and other authors, do not distinguish between the infant Jesus and the adult Christ who died on the cross. Although they seek to imitate the suffering Christ they identify with the infant Jesus.

${ }^{45}$ Beaune, AM, Archives du Carmel, 45, "Ancien recueil de cantiques," 8. "that we may have no mind or life other than to serve and love you, no desire or other wish than to completely consume ourselves in the pure love of your infancy which unites us to your cross and to your divine sufferings." 
Again, as discussed earlier, this is due to the belief that the infant Jesus knew and accepted his eventual suffering. The Discalced Carmelites, while imitating aspects of the divine infancy, also became united to Christ's divine sufferings.

Another example of this is found in an anonymous drawing of Marguerite du Saint Sacrement with the infant Jesus (Fig.8). The drawing depicts the infant Jesus in a small bed, as though in the manger, at the foot of a large cross. To the right is Marguerite du Saint Sacrement and to the left is an unidentified individual, perhaps Mary. Above, the clouds in the sky open and six childlike angels, or cherubim, look down. The caption below the image reads: "un jour le St. Enfant Jesus saparut a la V. Sr. Marguerite du St. Sacrement comme il ettoit an la creiche ou il luy fit voir une grande croix et luy dit ma fille je te vous aprendre la science de ma croix et de ma creiche." ${ }^{, 46}$ Again, we see that the crèche and the cross were inseparable in the minds of the Carmelites of Beaune. This powerful image of the vulnerable infant Jesus at the foot of the cross surely evoked feelings of adoration and a desire to unite oneself with the infancy and the Passion of Christ. The crèche and the cross were seen as integral components of salvation and indeed imagining oneself within or attached to these locations was essential to the Carmelites' imitatio Christi. Although we may find it difficult to fully comprehend how these two states of the life of Christ were so intimately linked, it is evident that this had intense meaning for the Carmelites of Beaune.

\footnotetext{
${ }^{46}$ Beaune, AM, Archives du Carmel, 21, "Pièces relatives à la Vénérable Soeur Marguerite du Saint Sacrement. Détails particuliers," 43. "One day the infant Jesus appeared to the venerable Marguerite du Saint Sacrement, as he was sitting in the manger, where he showed her a large cross and said to her "my daughter, I teach you the science of my cross and my manger."'
} 


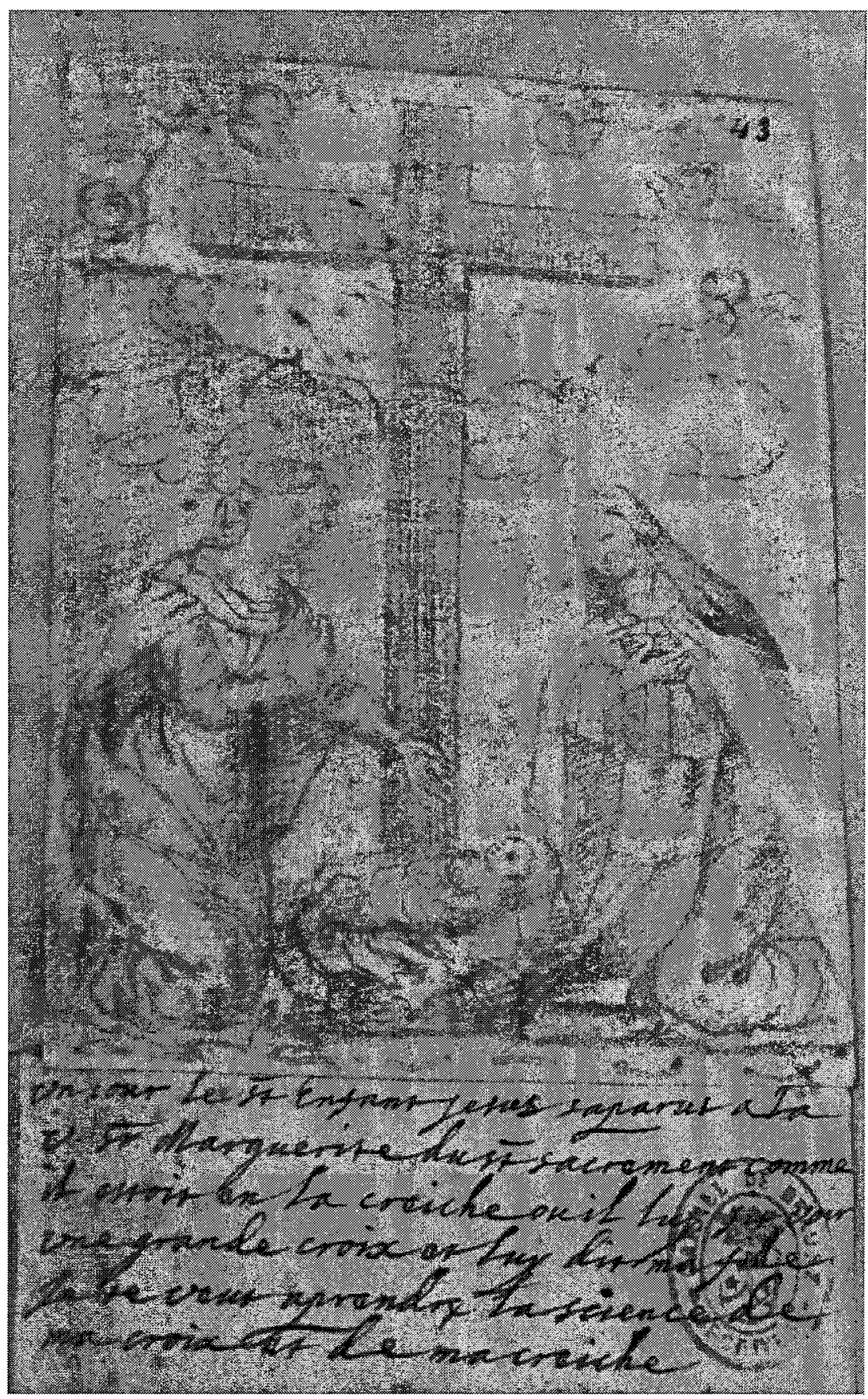

Fig. 8. Drawing of Marguerite du Saint Sacrement and the infant Jesus, Archives du Carmel, 21, 43, seventeenth century. 
A reason for why the Beaune spirituality considered the infancy and Passion to be inseparable may be in part due to their association with the confraternity of the Famille du saint enfant Jésus, dedicated to honouring Christ's infancy. One passage from a manual for this confraternity, and for the nuns, Le petit office du saint enfant Jésus, states that, "il [Christ] veut que l'Eglise se le represente sans cesse comme Enfant, et comme attaché à la Croix." ${ }^{47}$ Here, Discalced Carmelite spirituality of the infant Jesus is situated within the wider context of the Church as a whole. By stating that it was Christ's intention for the Church to represent him as an infant and as attached to the cross, the author justifies the devotion and links it to the authority of the Church. The manual continues to state that, "Il veut mesme que de son estat d'Enfance elle [the Church] fasse ses plus grandes Festes, et que dans cette foiblesse, et cette simplicité, elle le considere comme l'idée et l'exemplaire de l'Enfance spirituelle, dont il a ordonné qu'elle portast le caractere, lors qu'il a dit: Si vous ne devenez comme des Enfans, vous n'entrerez point dans le Royaume des Cieux." 48 This explanation for the devotion to the infant Jesus demonstrates the importance of linking a particular spirituality with the broader spirituality of the Church. Thus devotion to and imitation of the infant Jesus was significant because, according to this devotional manual, it fulfilled Christ's intention for his Church. Indeed the necessity of this devotion is heightened by the belief that the only way to enter into the Kingdom of Heaven is to become like a child. As we have seen, to become a child also means to endure Christ's Passion.

\footnotetext{
${ }^{47}$ Le petit office du saint enfant Jésus, 6-7. "He wants the Church to represent him constantly, as a child and as attached to the cross."

${ }^{48}$ Ibid., 7. "He wants even that of his infancy, she performs the greatest feasts, and that in this weakness and this simplicity, she consider him as the idea and exemplar of spiritual childhood, of which he ordered that she have the character, when he said: 'If you do not become like children, you will not enter the Kingdom of Heaven."
} 


\section{Conclusion}

To become a small child like the infant Jesus was the ultimate aim of the Discalced Carmelite spiritual life. Qualities such as humility, obedience and silence were considered the hallmarks of the divine infancy. Those who strived to become like the infant Jesus practiced these virtues. Their goal was to achieve "spiritual childhood" by imitating the infant Jesus. They lived their lives in imitation of Christ's life in Bethlehem and Nazareth, cloistered and hidden from the world. Imitating the infant Jesus, therefore, involved living in the crèche as he did. But the imitation of Christ's infancy did not overshadow or negate the imitation of his Passion. Indeed, in many ways the emphasis of the divine infancy facilitated the imitation of the Passion. Obedience to the infant Jesus and the divine will of his father included following and imitating Christ from his birth in the Bethlehem stable to his death at Calvary.

Marguerite du Saint Sacrement was considered the most devout imitator of the infant Jesus. It is therefore no wonder that her life is often compared with that of the infant Jesus, both in its childlike qualities and in its similarities with Christ's sufferings. She was frequently called "le chef d'oeuvre" of the infant Jesus precisely because she embodied all of the virtues explored above. ${ }^{49}$ Throughout the letters written about her we see her virtues often repeated: "conformity to the holy infancy, love of the divine will, insensitivity to all that was not God." ${ }^{\text {00 }}$ This last quality was also emphasized by Bérulle who as we saw earlier, suggested that individuals interest themselves solely with things of God. Marguerite's contemporaries believed that she lived a life of complete devotion to the divine infancy, surrendered herself entirely to the divine will and loved only that

\footnotetext{
${ }^{49}$ Marguerite du Saint Sacrement: Correspondance (lettres reçues), 651 and 723.

${ }^{50}$ Ibid., 725.
} 
which was of God. All of this stems from her imitation of the infant Jesus' childlike virtues and her embrace of his Passion and suffering. As one nun writes, the infant Jesus reigns "dans [his] berseau, en la croix et dans le calvaire." seek spiritual perfection in "l'enfance spirituelle" by imitating his cloistered infancy and childlike virtues, and his attitude of obedience to suffering, for the divine infancy can never be separated from the Passion.

${ }^{51}$ Archives du Carmel, 45, 6. "in [his] cradle, in the cross and in Calvary." 


\section{Conclusion}

Between 1631 and 1640 Elisabeth de la Trinité recorded the visionary experiences of Marguerite du Saint Sacrement and her interactions with the infant Jesus. According to these writings, the infant Jesus appeared to Marguerite numerous times, developing an intimate spiritual relationship with her. These divine encounters reveal an intimate association between Marguerite and the Holy Family and her intense devotion to the infant Jesus. In these visions, Marguerite accompanied the infant Jesus to the stable in Bethlehem where she became an active participant in his birth and childhood. She also joined the infant Jesus in his Passion and suffering when she was nailed to a cross in likeness of Christ's crucifixion. Indeed, these two aspects of the life of Christ, his birth and death, formed the center of the spirituality of the Discalced Carmelites of Beaune. Although these visions reveal the nature of Marguerite's devotion to the infant Jesus, the other nuns of the Beaune convent also embodied a spirituality focused on the Christ Child. As this thesis demonstrated, the Carmelites of Beaune practiced a very particular kind of devotion to the infant Jesus by seeing themselves as mothers, in imitation of Mary, and as children, in imitation of the infant Jesus.

The devotion to the infant Jesus did not focus solely on Christ's infancy and childhood to the neglect of honouring those highly involved in His early life. On the contrary, the devotion to the infant Jesus was highly intertwined, even dependent, upon honouring Mary and Joseph. The Discalced Carmelites of Beaune believed that while the infant Jesus was to be the center of their spiritual lives, devotion to Mary and Joseph was crucial in learning and practicing ways to honour the infant Jesus. 
In this way, devotion to the infant Jesus was not only about honouring and adoring Christ as a child, but it was also about being a part of His family. As this thesis explored, living as a member of the Holy Family required a number of specific devotional behaviours.

The Carmelites of Beaune practiced a unique spirituality in which they saw themselves as mothers of the infant Jesus. They contemplated Mary's thoughts and feelings throughout her pregnancy, the birth of the Christ and his early childhood. By mentally uniting themselves with Mary's experiences as the mother of Christ, the nuns identified with Mary and embodied certain maternal characteristics. These qualities included silence, joy and living a life away from the outside world. Not only did the Carmelites seek to imitate Mary's dispositions, or states of mind, but they also saw Joseph as a model for the interior life, the life of contemplation. Both Mary and Joseph were seen to have lived their lives in adoration of the infant Jesus who consumed all of their attention and affection. The Carmelites of Beaune imitated the role of Mary and Joseph by focusing their thoughts and feelings on the adoration of the infant Jesus.

The nun's imitation of Mary did not end with contemplation of her thoughts, emotions and spiritual connections with her son. Mary's physical relationship with the infant Jesus, including her pregnancy and the ways in which she cared for him throughout his infancy was also integrated into the spirituality of the Beaune convent. Through their reception of the Eucharist, the nuns were able to contain Christ within their bodies, acting as a kind of reliquary. Indeed, Mary was seen as the vessel of the Incarnation, as the house or dwelling place of the infant Jesus. Imagery of the body as a vessel of the infant Jesus is plentiful throughout the documents from the Beaune convent. The nuns, as well 
as the priests associated with the order, reinforced the similarities between Mary's pregnancy and the nuns' reception of the Eucharist.

Mary fed, bathed, embraced and cradled her son during his childhood, and the Carmelites of Beaune imitated these acts of maternal affection. Indeed, they often contemplated the tender images of mother and child and imagined themselves assuming the role of Mary, embracing and cradling the infant Jesus. Statues and visual representations of the Virgin and child throughout the Beaune convent provided the nuns with a model for how they should see their relationship with the Christ Child. By looking to Mary as the perfect example of motherly behaviour, the Carmelites of Beaune embodied a spirituality based upon maternal care of the infant Jesus.

This thesis, therefore, explores the ways in which the Discalced Carmelites of Beaune became mothers of the infant Jesus by imitating Mary. Although this constituted a powerful part of their spiritual lives, their devotion to the infant Jesus was also expressed by other means. The nuns sought to imitate the infant Jesus and therefore become children like him. Indeed, as explained in Chapter Three, the ultimate aim of the Carmelite life was to become a child after the example of the infant Jesus. In order to fulfill this goal, the nuns contemplated the life of Christ during his early years in Bethlehem and Nazareth with Mary and Joseph. This life was characterized by silence and obedience. The nuns, therefore, sought to foster these qualities within themselves. The life of the infant Jesus in Bethlehem and Nazareth was seen to be hidden from the world, and indeed, the nuns sought to live "la vie cachée" in imitation of the Holy Family. For the Carmelites, this hidden life involved living a life of strict claustration 
within the convent walls. Indeed, the cloister was frequently compared to the stable in which the infant Jesus was born, thus linking the life of Christ with that of the nuns.

Although the nuns imitated the infant Jesus by living in the cloister as the Holy Family did in Bethlehem and developing childlike qualities, they also sought to imitate the sufferings and Passion of Christ. This is perhaps the most complex and least understood aspect of this spirituality. In their efforts to identify with the suffering Christ and embody his Passion, the Carmelites contemplated and saw themselves as imitating the infant Jesus, not the adult Christ. In part, this demonstrates the extent to which the infant Jesus was at the center of every aspect of their lives. It also reveals the ways in which the divine infancy was seen to be deeply intertwined with the Passion. Indeed, a major characteristic of the Beaunois devotion to the infant Jesus was the inseparability of the infancy and the Passion. In their imitation of Christ's Passion, the nuns contemplated the sufferings of the infant Jesus and the joy with which he endured such pain for the salvation of men. Because he was God, the infant Jesus knew of the suffering he would endure and the Carmelites of Beaune honoured, adored and imitated his attitude of voluntary suffering.

The ways in which the Discalced Carmelites of Beaune practiced their devotion to the infant Jesus are deeply complex. This thesis has sought to explain the particular devotional activities, both mental and physical, of the Carmelite nuns of Beaune. This study is by no means an exhaustive or complete analysis of the devotion to the infant Jesus among these nuns. Nonetheless, this thesis has delved deeper than any previous study of French Carmelites and explored the spirituality and devotional activities of the nuns. The ways in which the Carmelites of Beaune imitated Mary the infant Jesus are 
significant since they operate within the wider context of seventeenth- century French Catholicism as well as the history of the Discalced Carmelite order. In addition, this study endeavoured to contribute to the historiography of early modern women's religious communities by exploring their spirituality, a subject that has received little scholarly attention. Perhaps this study will be a part of future efforts to uncover the spiritual lives of nuns.

While this thesis explored several aspects of the spirituality of the Carmelites of Beaune, much remains to be explored and analyzed in greater detail. Chapter One discussed the founding of the Beaune convent and the dynamic relationship between the laity and the nuns. More exploration into the initial resistance of the local population and the subsequent close ties between the cloister and the laity would contribute to a more thorough understanding of the ways in which the devotion to the infant Jesus extended beyond the convent walls. Additionally, this devotion was prominent among most, if not all, Discalced Carmelite convents in France. Studies of other convents or the devotional practices of the order in general would be greatly beneficial to our overall understanding of the French Discalced Carmelites.

While this thesis situated the Beaunois devotion to the infant Jesus within the religious context of the école française, it would be interesting to explore these links further. Doing so would facilitate a greater understanding of the relationship between priests, lay individuals, and the nuns. Moreover, the confessional tension between Protestants and Catholics, the ways in which this may have influenced the development of the spirituality of the école française and consequently the Carmelites of France, is another area of fruitful study. 
After the death of Marguerite du Saint Sacrement on May 26, 1648, the devotion to the infant Jesus, with which she was intimately connected, continued to spread and thrive throughout the Discalced Carmelite convents in France. Devotional fervour was so intense that individuals sought anything that had a connection to her: rosaries, paintings, wax statues of the infant Jesus, and other devotional objects. Marguerite was seen as the most devout imitator of the infant Jesus and those who sought to live a life of perfect devotion endeavoured to follow her example. She was known as a chosen daughter of the Virgin Mary and the one selected by the infant Jesus himself to spread the devotion to his divine infancy.

The nuns who lived in the Beaune convent during Marguerite's life were undoubtedly influenced by her intense spiritual connection to the Holy Family. The Carmelites of Beaune sought to follow Marguerite's example because she lived her life in imitation of the members of the Holy Family. Moreover, and most importantly, she always kept the infant Jesus at the center of her spiritual life. Through the imitation of Mary's motherhood, the Carmelites entered into an intimate, affectionate relationship with the infant Jesus. The nuns also sought to unite themselves with his suffering and Passion, thereby integrating the devotion to the divine infancy into the adoration and imitation of Christ's sufferings. Whether they assumed the role of affectionate mother, innocent child, or suffering saviour, the Carmelites of Beaune united themselves with the Christ Child and led lives of perpetual adoration of the infant Jesus. 


\section{Bibliography}

\section{Primary Sources}

\section{Archives of the Beaune Convent}

Beaune. Archives Municipales. Archives du Carmel. 1. "L'ordre des devoirs et des obligations des domestiques et associées de la famille de Jésus Enfant".

Beaune. Archives Municipales. Archives du Carmel. 2. "Copie d'un fragment des 'Mémoires de la Vie'”.

Beaune. Archives Municipales. Archives du Carmel. 11. "Petit recueil de grâces qu'il a plu au St. Enfant Jésus départir à sa petite épouse."

Beaune. Archives Municipales. Archives du Carmel. 21. "Pièces relatives à la Vénérable Soeur Marguerite du Saint Sacrement."

Beaune. Archives Municipales. Archives du Carmel. 26. "Dévotion à la Vénérable Soeur Marguerite du Saint Sacrement."

Beaune. Archives Municipales. Archives du Carmel. 29. "Premier livre des cantiques du Carmel de Beaune."

Beaune. Archives Municipales. Archives du Carmel. 39. "Correspondance".

Beaune. Archives Municipales. Archives du Carmel. 40. "Fondation du Monastère des Carmélites de Beaune."

Beaune. Archives Municipales. Archives du Carmel. 45. "Ancien recueil de cantiques."

\section{Seventeenth-Century Printed Sources}

Amelote, Denis. La vie de Soeur Marguerite du Saint Sacrement, religieuse Carmélite du monastère de Beaune. Paris: Pierre le Petit, 1655.

Bérulle, Pierre de. La vie de Soeur Catherine de Jésus, religieuse de l'Ordre de NostreDame du Mont-Carmel, estably en France, selon la réformation de Saincte Térèse de Jésus, décédée au convent du mesme Ordre, dit de la Mère de Dieu, en la ville de Paris, le 19 février 1620 (1623). Avec un recueil de ses lettres et pieux escrits. Paris: Fiacre Dehors, 1631.

Senault, Jean- Francois. La vie de la Mère Magdeleine de S. Joseph, religieuse Carmélite déchaussée, de la première règle selon la réforme de Saint Thérèse. Paris: P. Le Petit, 1670. 
Institution de la famille du saint enfant Jésus. Lyon: Pierre Campagnon et Robert Taillandier, 1669.

La vie de Soeur Catherine de Jésus, religieuse de l'ordre de Nostre Dame du Mont Carmel. Paris: Fiacre Dehors, 1628.

Le petit office du saint enfant Jésus. Paris: François Muguet, 1697.

Préparation à la vie religieuse. Paris: Simeon Piget, 1664.

\section{Modern Editions}

Grivot, Marie-Françoise, o.c.d., ed. Marguerite du Saint-Sacrement: Correspondance, lettres écrites par elle, reçues par elle et écrites à son sujet. Habillages: Beaune, 1991.

. Marguerite du Saint Sacrement: Correspondance (lettres reçues à son sujet). vol.1-4. Lanzy: Forelle, 1997-2002.

Oeuvres complètes de Bérulle disposées dans un ordre logique. Paris: Migne, 1856.

\section{Secondary Sources}

Bergeron, Henri-Paul. "Saint Joseph dans la prédication française au XVIIe siècle." Cahiers de Joséphologie 30 (1982): 23-59.

Blaisdell, Charmarie. "Religion, Gender, and Class: Nuns and Authority in Early Modern France." In Changing Identities in Early Modern France, edited by Michael Wolfe, 147168. Durham: Duke University Press, 1997.

Brémond, Henri. Histoire littéraire du sentiment religieux en France: depuis la fin des guerres de religion jusqu'à nos jours. vol.3. Paris: Librairie Armand Colin, 1967.

Bynum, Caroline Walker. Fragmentation and Redemption: Essays on Gender and the Human Body in Medieval Religion. New York: Zone Books, 1991. . Holy Feast and Holy Fast: The Religious Significance of Food to Medieval Women. Los Angeles: University of California Press, 1987.

Caudwell, Francois. "L'église réformée de Beaune au XVIIe siècle." Bulletin de la Société de l'Histoire du Protestantisme Français 138 (1992): 343-367.

Châtellier, Louis. Le Catholicisme en France, 1500-1650, tome I: le XVIe siècle. Paris: Sedes, 1995. 
Constable, Giles. Three Studies in Medieval Religious and Social Thought. Cambridge: Cambridge University Press, 1995.

Cupples, Cynthia J. “'Between You and Us': Nuns and Spiritual Discernment in Seventeenth-Century France." Proceedings of the Western Society for French History 33 (2005): 114-130.

."Plus que l'exemple de ses saintes vertus": Catholic Women and the Communication of Relics in Seventeenth-Century France." Proceedings of the Western Society for French History 31 (2003): 17-32.

Délissey, Joseph. Le vieux Beaune. Beaune: Imprimerie Mad. Girard, 1941.

Della Croce, Giovanna, o.c.d. L'enfant Jésus au Carmel: histoire et spiritualité.

Translated by Raymond Lamarque. Toulouse: Éditions du Carmel (Collection Carmel Vivant), 2005.

Delumeau, Jean. Catholicism Between Luther and Voltaire: A New View of the CounterReformation. London: Burns and Oates Limited, 1977.

Diefendorf, Barbara B. From Penitence to Charity: Pious Women and the Catholic Reformation in Paris. Oxford: Oxford University Press, 2004.

Dompnier, Bernard. "Les religieux et saint Joseph dans la France de la première moitié du XVIIème siècle." In Religieux, saints et dévotions, France et Pologne, XIIIèmeXVIIème s., edited by Bernard Dompnier, 57-75. Paris: Presses Université Blaise Pascal, 2003.

. "Thérèse d'Avila et la dévotion française à saint Joseph au XVIIe siècle." Revue d'histoire de l'Église de France 90 (2004):175-190.

Dzon, Mary. "The Image of the Wanton Christ-Child in the Apocryphal Infancy Legends of Late Medieval England.” PhD diss., University of Toronto, 2004.

Ellington, Donna Spivey. From Sacred Body to Angelic Soul: Understanding Mary in Late Medieval and Early Modern Europe. Washington: The Catholic University of America Press, 2001.

Evennett, H. Outram. The Spirit of the Counter-Reformation. Cambridge: Cambridge University Press, 1968.

Farr, James R. Authority and Sexuality in Early Modern Burgundy (1550-1730). New York: Oxford University Press, 1995. 
Foisil, Madeleine. "La figure de Madame Acarie, Marie de l'Incarnation, à travers 1'historiographie du XVIIe au XIXe siècle." In Carmes et Carmélites en France, edited by Bernard Hours, 155-170.

Hale, Rosemary. "Imitatio Mariae: Motherhood Motifs in Devotional Memoirs." Mystics Quarterly 16 (1990): 193-203.

. "Imitatio Mariae: Motherhood Motifs in Late Medieval German Spirituality." PhD diss., Harvard University, 1992.

. "Rocking the Cradle: Margaretha Ebner (Be)Holds the Divine." In Performance and Transformation: New Approaches to Late Medieval Spirituality, edited by Mary a. Suydam and Joanna E. Ziegler, 211-239. New York: St. Martin's Press, 1999.

Herlihy, David. Women, Family and Society in Medieval Europe, Historical Essays 19781991. Providence: Berghahn Books, 1995.

Hours, Bernard, ed. Carmes et Carmélites en France du XVIle siècle à nos jours. Paris: Les Éditions du Cerf, 1997.

Holt, Mack. The French Wars of Religion, 1562-1629. New York: Cambridge University Press, 1995.

Johnson, Penelope. Equal in Monastic Profession: Religious Women in Medieval France. Chicago: The University of Chicago Press, 1991.

Marx, Jacques. "Marguerite du Saint Sacrement, le roi et le petit Jésus." Revue belge de philologie et d'histoire 83 (2005): 1133-1154.

Meyer, Frédéric. "Carmélites et laïques dévots: l'example des fondations comtadines." In Carmes et Carmélites en France, edited by Bernard Hours, 7-18.

Morgain, Stéphane-Marie. Pierre de Bérulle et les Carmélites de France: la querelle du gouvernement 1583-1629. Paris: Les Éditions du Cerf, 1995.

Muir, Edward. Ritual in Early Modern Europe. Cambridge: Cambridge University Press, 1997.

O'Malley, John. Trent and All That: Renaming Catholicism in the Early Modern Era. Cambridge: Harvard University Press, 2000.

Rocher, Yves, ed. Musée du Petit Palais. L'art du XVIIe siècle dans les carmels de France. Paris. (17 novembre 1982 - 15 février 1983).

Rapley, Elizabeth. A Social History of the Cloister: Daily Life in the Teaching Monasteries of the Old Regime. Montreal: McGill-Queen's University Press, 2001. 
.The Dévotes: Women and Church in Seventeenth-Century France. Montreal: McGill-Queen's University Press, 1990.

Renoux, Christian. "Madame Acarie 'lit' Thérèse d'Avila au lendemain de l'édit de Nantes." In Carmes et Carmélites en France, edited by Bernard Hours, 117-154.

Roland-Gosselin, Jacques. Le Carmel de Beaune: 1619-1660. Morocco: Imprimeries Françaises et Marocaines, 1969.

Rossignol, Claude. Histoire de Beaune depuis les temps les plus reculés jusqu'à nos jours. Beaune: Imprimerie Ed. Batault-Morot, 1854.

Saward, John. "The Earthly Home of the Eternal Father': The Holy Family in the Spirituality of the French School." In The Holy Family in Art and Devotion, edited by Joseph F. Chorpenning, 54-64. St. Joseph's University Press: Philadelphia, 1998.

Serouet, Pierre. "Le culte de saint Joseph dans le carmel de France au XVIIe siècle." Cahiers de Joséphologie 29 (1981): 770-792.

Sr. Jehanne d'Arc. "Le bonheur de l'autre monde." 1. Recorded November 29-30 2008 at the Centre Spirituel des Sables d'Olonne "Relais Pascal", available at http://www.exultet.net.

Suire, Éric. "La sainteté carmélitaine, d'après la littérature hagiographique des XVIIeXVIIIe siècles." In Carmes et Carmélites en France, edited by Bernard Hours, 171-189.

Viller, Marcel. et al., eds. Dictionnaire de spiritualité ascétique et mystique: doctrine et histoire. 17 vols. Paris: Beauchesne, 1932-1995.

Warner, Marina. All Alone of Her Sex: The Myth and the Cult of the Virgin Mary. New York: Alfred A. Knopf, 1976.

Wiesner, Merry E. Women and Gender in Early Modern Europe. Cambridge: Cambridge University Press, 2000. 